\title{
Water-Quality and Physical Characteristics of Streams in the Treyburn Development Area of Falls Lake Watershed, North Carolina, 1994-98
}

By Carolyn J. Oblinger, Thomas F. Cuffney, Michael R. Meador, and Ronald G. Garrett

U.S. GEOLOGICAL SURVEY

Water-Resources Investigations Report 02-4046

Prepared in cooperation with the

North Carolina Department of Environment and Natural Resources,

Division of Water Quality

Raleigh, North Carolina

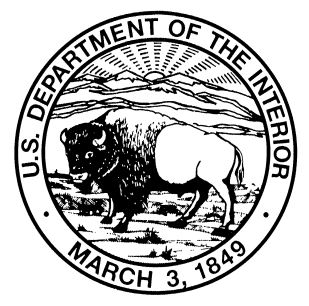




\section{U.S. DEPARTMENT OF THE INTERIOR \\ GALE A. NORTON, Secretary}

U.S. GEOLOGICAL SURVEY

CHARLES G. GROAT, Director

The use of firm, trade, and brand names in this report is for identification purposes only and does not constitute endorsement by the U.S. Geological Survey.

Additional information about U.S. Geological Survey programs and products can be obtained from the website: http://nc.water.usgs.gov.

For additional information write to:

Copies of this report can be purchased from:

District Chief

U.S. Geological Survey

3916 Sunset Ridge Road

Raleigh, NC 27607

dc_nc@usgs.gov
U.S. Geological Survey

Branch of Information Services

Box 25286, Federal Center

Denver, CO 80225

1-888-ASK-USGS 


\section{CONTENTS}

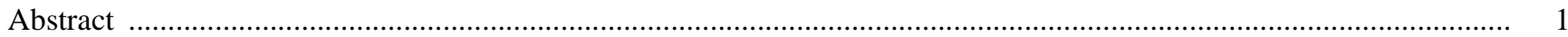

Introduction

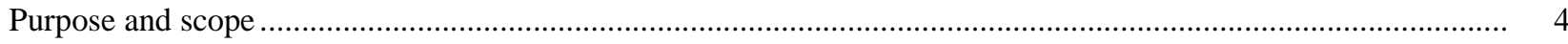

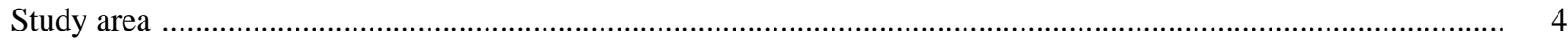

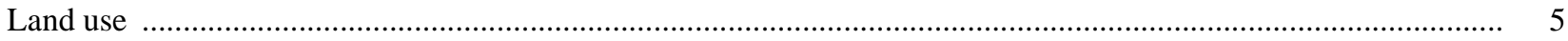

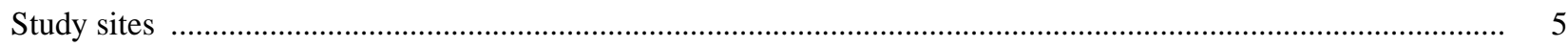

Data collection

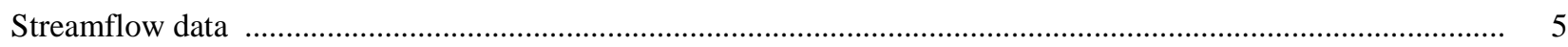

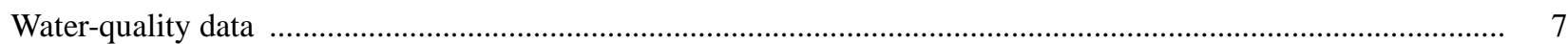

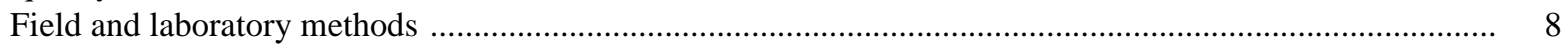

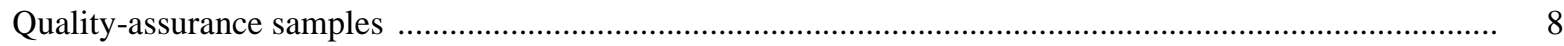

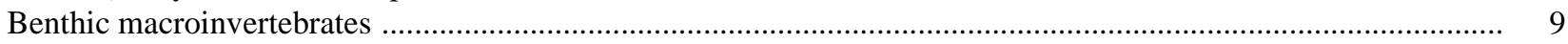

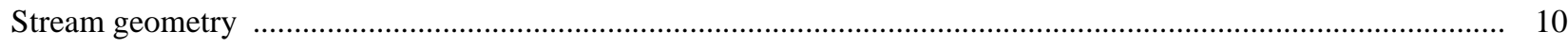

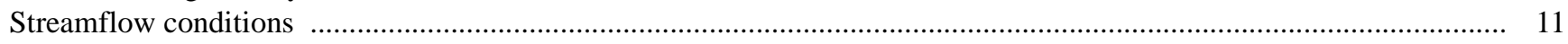

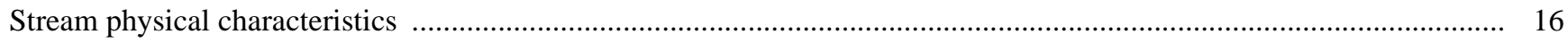

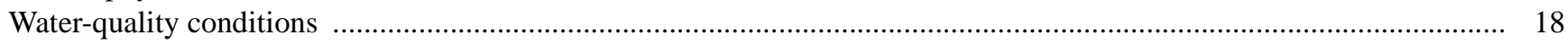

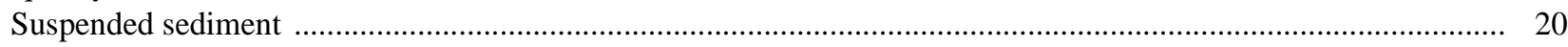

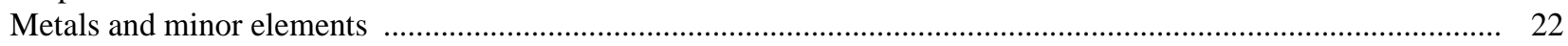

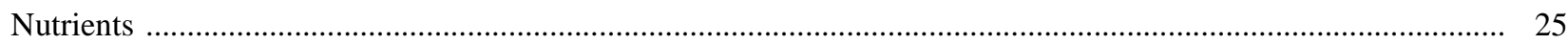

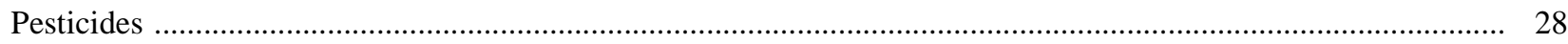

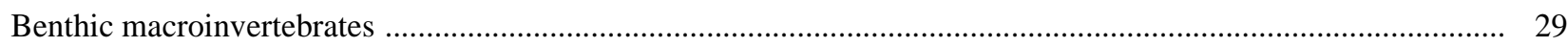

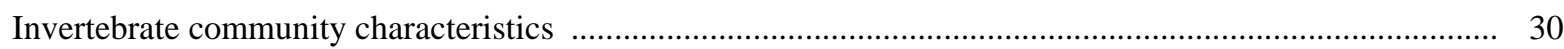

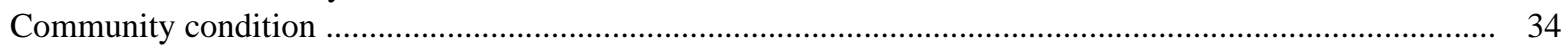

Patterns in invertebrate distributions and physical and chemical factors ............................................. 35

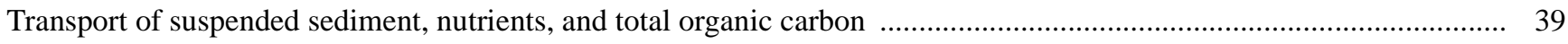

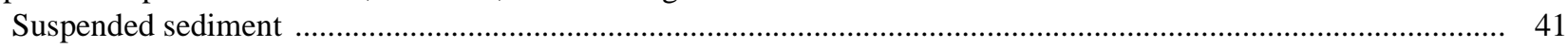

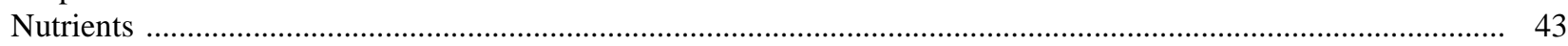

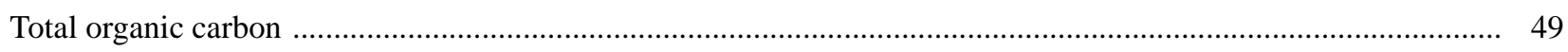

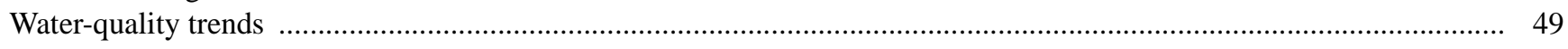

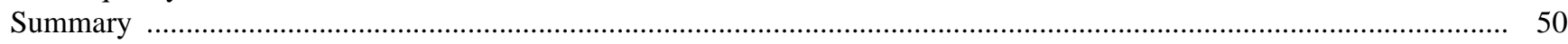

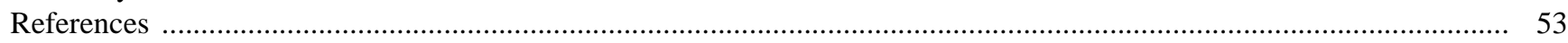

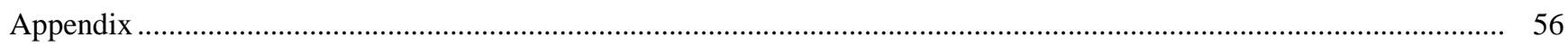

\section{FIGURES}

1-2. Maps showing:

1. Location of the Treyburn development and study area in the upper Neuse River Basin,

2. Locations of study sites in the Treyburn development area of North Carolina .......................................... 6

3-8. Graphs showing:

3. Mean monthly streamflow for (A) water years 1989-93 and (B) water years 1994-98 and long-term mean monthly streamflow (1925-98) at the Flat River at Bahama, North Carolina

4. Annual rainfall amounts for water years 1990-98 and long-term mean annual rainfall (1960-90) at a National Oceanic and Atmospheric Administration site in northern Wake County, North Carolina

5. (A) Instantaneous discharge measurements at Flat River and Little River tributaries, 1994-98, and (B) relation between discharges at Flat River and Little River tributaries in the Treyburn development study area, North Carolina 
6. Long-term discharge frequency and instantaneous discharge frequency for sampled discharges at gaged water-quality sites in the Treyburn development study area, North Carolina

7. Discharge for water years 1994-98 at Little River below Little River tributary

at Fairntosh (site 10TA), Flat River at Bahama (site 5T), Mountain Creek (site 6T), and Flat River tributary (site 1T)

8. Relation between mean bank angle and mean channel width-to-depth ratio for sites

in the Treyburn development study area

9. Box plots showing the mean and range of measured bank angles at sites in the Treyburn

development study area

10-12. Graphs showing:

10. Major anion and cation concentrations in low-flow samples collected from

Mountain Creek, Flat River, Flat River tributary, and Little River in June 1991, and from Little River tributary in January 1992

11. Relation between (A) specific conductance and unit discharge, and (B) $\mathrm{pH}$ and unit discharge for Mountain Creek, Flat River tributary, Flat River, Little River tributary, and Little River

12. (A) Distribution of suspended sediment, by site, and (B) relation of suspended-sediment concentrations to discharge at sites in the Treyburn development study area

13. Box plots showing the distribution of nutrients, by site, in the Treyburn development study area, and the results of significance testing

14. Time line of the application dates for fungicides, herbicides, and insecticides on the Treyburn Golf Course within the Little River tributary drainage basin, and pesticide sampling dates for 1997-98

15-16. Graphs showing:

15. North Carolina Biotic Index (NCBI) values obtained by the U.S. Geological Survey and by the North Carolina Division of Water Quality for sites in the Treyburn development study area

16. Relations among Treyburn development study area sites, based on (A) richest targeted

habitat (RTH), (B) qualitative multihabitat (QMH), and (C) depositional targeted habitat (DTH) samples

17. Hydrographs of (A) suspended sediment and (B) streamflow at Flat River at Bahama

for water years $1989-98$

18-20. Graphs showing:

18. Annual and median suspended-sediment yields at the Treyburn development study area sites for water years 1989-98

19. Annual and median total nitrogen and nitrite-plus-nitrate yields at the Treyburn development study area sites for water years $1989-98$

20. Annual and median total phosphorus and orthophosphate yields at the Treyburn development study area sites for water years $1989-98$

\section{TABLES}

1. Data-collection sites in the Treyburn development study area, North Carolina

2. Concentrations of nutrients in replicate and blank quality-assurance samples collected for the Treyburn development study

3. Reporting levels for environmental and blank samples, and concentrations of metals in blank quality-assurance samples collected for the Treyburn development study

4. Streamflow characteristics for gaged sites in the Treyburn development study area

5. Summary of physical characteristics of streams in the Treyburn development study area, February 1997

6. Summary statistics for physical measurements and suspended sediment collected at five sites in the Treyburn development study area, 1994-98

7. Summary statistics for metals and minor elements collected at five sites in the Treyburn development study area, 1994-98 
8. Summary statistics for nutrients detected in stream samples collected at five sites in the Treyburn development study area, 1994-98

9. Concentrations of pesticides that exceeded the laboratory reporting level in six stream samples collected at each of three sites in the Treyburn development study area, water years 1996-98

10. Number of taxa collected, and selected benthic invertebrate assemblage richness and abundance metrics for sites in the Treyburn development study area

11. Number of sites where benthic macroinvertebrate taxa were collected at small, midsize, and river sites in the Treyburn development study area, and the tolerance value for each taxa

12. Benthic macroinvertebrate assemblage metrics used in the calculation of the North Carolina Biotic Index, and North Carolina Division of Water Quality site-condition ratings for sites in the Treyburn development study area

13. Correlations between physical and chemical variables and drainage-basin size, and ordination site scores for macroinvertebrate samples from sites in the Treyburn development study area

14. Regression models used to estimate nutrient, suspended-sediment, and total organic carbon loads at five sites in the Treyburn development study area

15. Annual and median suspended-sediment yield and load for water years 1989-98 at Treyburn development study area sites

16. Mean annual yields of suspended sediment, total nitrogen, total phosphorus, and total organic carbon in the Treyburn development study area, and selected watersheds in the upper

Neuse River Basin and in the Charlotte metropolitan area

17. Annual and median total nitrogen yield and load for water years 1989-98 at Treyburn development study area sites

18. Annual and median total nitrite-plus-nitrate nitrogen yield, and total ammonia plus organic nitrogen yield for water years 1989-98 at Treyburn development study area sites

19. Annual and median total phosphorus yield and load for water years 1989-98 at Treyburn development study area sites

20. Annual and median total orthophosphate yield, and total organic carbon yield for water years 1989-98 at Treyburn development study area sites

21. Results of seasonal trend analysis for nitrogen and phosphorus species, total organic carbon, and suspended sediment at Treyburn development study area sites

\section{APPENDIX TABLES}

1. Cross-section survey data collected in February 1997 at eight sites in the Treyburn development study area, North Carolina.

2A. Density of benthic macroinvertebrates collected in richest targeted habitat (RTH) samples and the tolerance values used by the North Carolina Division of Water Quality to calculate the North Carolina Biotic Index

2B. Density of benthic macroinvertebrates collected in depositional targeted habitat (DTH) samples and the tolerance values used by the North Carolina Division of Water Quality to calculate the North Carolina Biotic Index 
Conversion Factors, Sea Level, Specific Conductance, Temperature, and Abbreviated Water-Quality Units

\begin{tabular}{|c|c|c|}
\hline Multiply & By & To obtain \\
\hline \multicolumn{3}{|c|}{ Length } \\
\hline inch (in.) & 2.540 & centimeter \\
\hline foot $(\mathrm{ft})$ & 0.3048 & meter \\
\hline mile (mi) & 1.609 & kilometer \\
\hline \multicolumn{3}{|c|}{ Area } \\
\hline acre & 0.4047 & hectare \\
\hline square foot $\left(\mathrm{ft}^{2}\right)$ & 0.0929 & square meter \\
\hline square mile $\left(\mathrm{mi}^{2}\right)$ & 2.590 & square kilometer \\
\hline \multicolumn{3}{|c|}{ Volume } \\
\hline cubic foot $\left(\mathrm{ft}^{3}\right)$ & 0.02832 & cubic meter \\
\hline \multicolumn{3}{|l|}{ ( } \\
\hline cubic foot per second $\left(\mathrm{ft}^{3} / \mathrm{s}\right)$ & 0.02832 & cubic meter per second \\
\hline cubic foot per second per square mile $\left[\left(\mathrm{ft}^{3} / \mathrm{s}\right) / \mathrm{mi}^{2}\right]$ & 0.01093 & cubic meter per second per square kilometer \\
\hline \multicolumn{3}{|c|}{ Mass } \\
\hline ton per day (ton/d) & 0.9072 & megagram per day \\
\hline
\end{tabular}

Sea level refers to the National Geodetic Vertical Datum of 1929 (NGVD of 1929) - a geodetic datum derived from a general adjustment of the first-order level nets of both the United States and Canada, formerly called Sea Level Datum of 1929.

$\underline{\text { Specific conductance }}$ is given in microsiemens per centimeter at 25 degrees Celsius $\left(\mu \mathrm{S} / \mathrm{cm}\right.$ at $\left.25^{\circ} \mathrm{C}\right)$.

Temperature: Water temperature is given in degrees Celsius $\left({ }^{\circ} \mathrm{C}\right)$, which can be converted to degrees Fahrenheit $\left({ }^{\circ} \mathrm{F}\right)$ as follows:

$$
{ }^{\circ} \mathrm{F}=\left({ }^{\circ} \mathrm{C} \times 1.8\right)+32
$$

Air temperature is given in degrees Fahrenheit $\left({ }^{\circ} \mathrm{F}\right)$, which can be converted to degrees Celsius $\left({ }^{\circ} \mathrm{C}\right)$ as follows:

$$
{ }^{\circ} \mathrm{C}=\left({ }^{\circ} \mathrm{F}-32\right) / 1.8
$$

Abbreviated water-quality units: $\quad \mu \mathrm{g} / \mathrm{L}$, microgram per liter $\mathrm{mg} / \mathrm{L}$, milligram per liter

$\mathrm{L}$, liter (a unit of volume equal to approximately 1.057 quarts)

$\mathrm{cm}$, centimeter (a unit of length equal to $0.3937 \mathrm{inch}$ )

micron (a unit of length equal to one millionth $\left(10^{-6}\right)$ of a meter)

$\mathrm{m}^{2}$, square meter (a unit of area equal to 1.2 square yards) 


\title{
Water-Quality and Physical Characteristics of Streams in the Treyburn Development Area of Falls Lake Watershed, North Carolina, 1994-98
}

\author{
By Carolyn J. Oblinger, Thomas F. Cuffney, Michael R. Meador, and Ronald G. Garrett
}

ABSTRACT

Treyburn is a 5,400-acre planned, mixed-use development in the upper Neuse River Basin of North Carolina. The development, which began in 1986, is located in the Falls Lake watershed near three water-supply reservoirs - Lake Michie to the north, Falls Lake to the southeast, and Little River Reservoir to the west. A study began in 1988 to determine the water-quality characteristics of surface waters in and around the Treyburn development area.

Data to characterize water quality at five different sites were collected from July 1994 through September 1998. Data from a previous study are available for some sites for the period 1988-93. The sites were selected to characterize water quality and quantity in and near the Treyburn development and included an undeveloped basin, a relatively small basin containing single-family residences and a golf course, a basin downstream from the western part of the development with some industrial land use, and two basins unaffected by the development where agricultural land is being converted to urban and forested land use.

Suspended-sediment concentrations ranged from less than 1 to 581 milligrams per liter and were fairly uniform among the five sites. Median suspended-sediment concentrations ranged from 12 to 21 milligrams per liter. Few concentrations of metals and trace elements, except aluminum, iron, and manganese, exceeded the laboratory reporting levels or water-quality criteria. At one site, concentrations of silver exceeded both the action level and the reporting level; copper was detected at each site and exceeded the action level of 7 micrograms per liter at one site.

The lowest range and median concentrations of total organic nitrogen, nitrate, ammonia, total phosphorus, and orthophosphorus occurred in the relatively undisturbed, forested site. The maximum concentration of organic nitrogen (1.97 milligrams per liter) occurred at one of the sites unaffected by the Treyburn development where agricultural land is being converted to urban land use. At all sites, ammonia concentrations ranged from less than 0.02 to 0.36 milligram per liter, and median concentrations were near the reporting level. Nitrate concentrations ranged from less than 0.05 to 0.80 milligram per liter.

Phosphorus concentrations at all of the Treyburn study sites were low compared to phosphorus concentrations that typically exceed 0.1 milligram per liter at sites sampled nationally for the U.S. Geological Survey National Water-Quality Assessment Program, including the AlbemarlePamlico study area in North Carolina. Total phosphorus concentrations ranged from less than 0.01 to 0.87 milligram per liter, and orthophosphorus concentrations ranged from less than 0.01 to 0.76 milligram per liter as phosphorus. The maximum concentrations of total phosphorus and orthophosphorus occurred at the Treyburn residential and golf-course site, likely as a result of the fertilizer applications associated with these two types of land use. 
Of the 119 different pesticides tested, 11 were detected in concentrations that exceeded the laboratory reporting levels, though in very low concentrations. Water samples from the residential and golf-course site contained the greatest number of pesticides (10). Five of six samples collected at this site had detectable concentrations of simazine, atrazine, and pendimethalin — all herbicides used to control weeds in crops or turf.

Channel geometry was assessed at eight sites in the study area in February 1997. These sites were separated into three groups based on mean bank angle and mean channel width-to-depth ratios. Channel gradient ranged from 0.04 to 1.63 percent, and mean cross sectional area ranged from 31 to 1,227 square feet.

Three macroinvertebrate samples were collected from each of 10 sites. These three samples were from areas designated as richest targeted habitats, depositional targeted habitats, and qualitative multitargeted habitats. Over 230 taxa were identified from these 10 sites. The North Carolina Biotic Indices ranged from 4.98 (excellent) to 6.82 (fair). River sites tended to have higher total taxa richness (91-108) than did the small, intermittent streams (49-84) or the midsize Mountain Creek (85). Intermittent streams represent fairly hostile environments for most aquatic organisms. Samples from richest targeted habitats typically were more than twice as rich as samples from depositional targeted habitats and represented from 50 to 75 percent of the taxa found at each site (mean of 62 percent). The industrial site lacked many of the mayfly taxa that were present at the undeveloped site. Mayflies are very sensitive to metals contamination, and their absence may indicate a possible problem. The supporting chemical information is not available for the industrial site, and additional study would be necessary to substantiate this possibility. The two sites with residential and golf-course land use tended to support more different types of sensitive invertebrates (that is, mayflies, stoneflies, and caddis flies) than did the forested/residential site, though the abundances of these taxa were very similar. Land-use effects were not evident based on a comparison among these sites.

Indirect gradient analysis was used to determine patterns in the distribution of invertebrates and to examine the relations between these patterns and physical and chemical site characteristics determined in this study. This analysis supports the contention that the dominant factors accounting for the distribution of benthic invertebrates are associated with natural factors, such as basin size, rather than land use.

Constituent loads at five study sites were calculated for nutrients, suspended sediment, and total organic carbon. The median annual total nitrogen yield ranged from 0.635 to 1.63 tons per square mile. The median annual phosphorus yield ranged from 0.046 to 0.619 ton per square mile, and the median annual orthophosphate yield ranged from 0.022 to 0.379 ton per square mile. Orthophosphate accounted for more than half of the phosphorus yield at the residential and golf-course site.

The maximum suspended-sediment yield was 422 tons per square mile, and the minimum yield was 32 tons per square mile. The suspended-sediment yield at one of the sites unaffected by the Treyburn development where agricultural land was being converted to urban land use was high compared to other forested basins in the Piedmont of North Carolina.

Total organic carbon data sufficient for estimating loads were available at three of the five sites. Of these three sites, the undeveloped site had substantially more organic carbon yield than the other two sites.

The only significant water-quality trend (alpha $=0.05$ ) was a downward trend for total nitrogen and organic nitrogen at the undeveloped site. The trend slope was small, only 0.019 milligram per liter as nitrogen or less than 9 percent of the median organic nitrogen concentration. No trend was observed for nitrite plus nitrate or for ammonia, indicating that the downward trend in total nitrogen was due only to organic nitrogen.

\section{INTRODUCTION}

Treyburn is a 5,400-acre planned, mixed-use development located in the Falls Lake watershed in the upper Neuse River Basin of North Carolina (fig. 1). The development began in 1986 and consists of residential, industrial, and recreational facilities. The remainder of the 


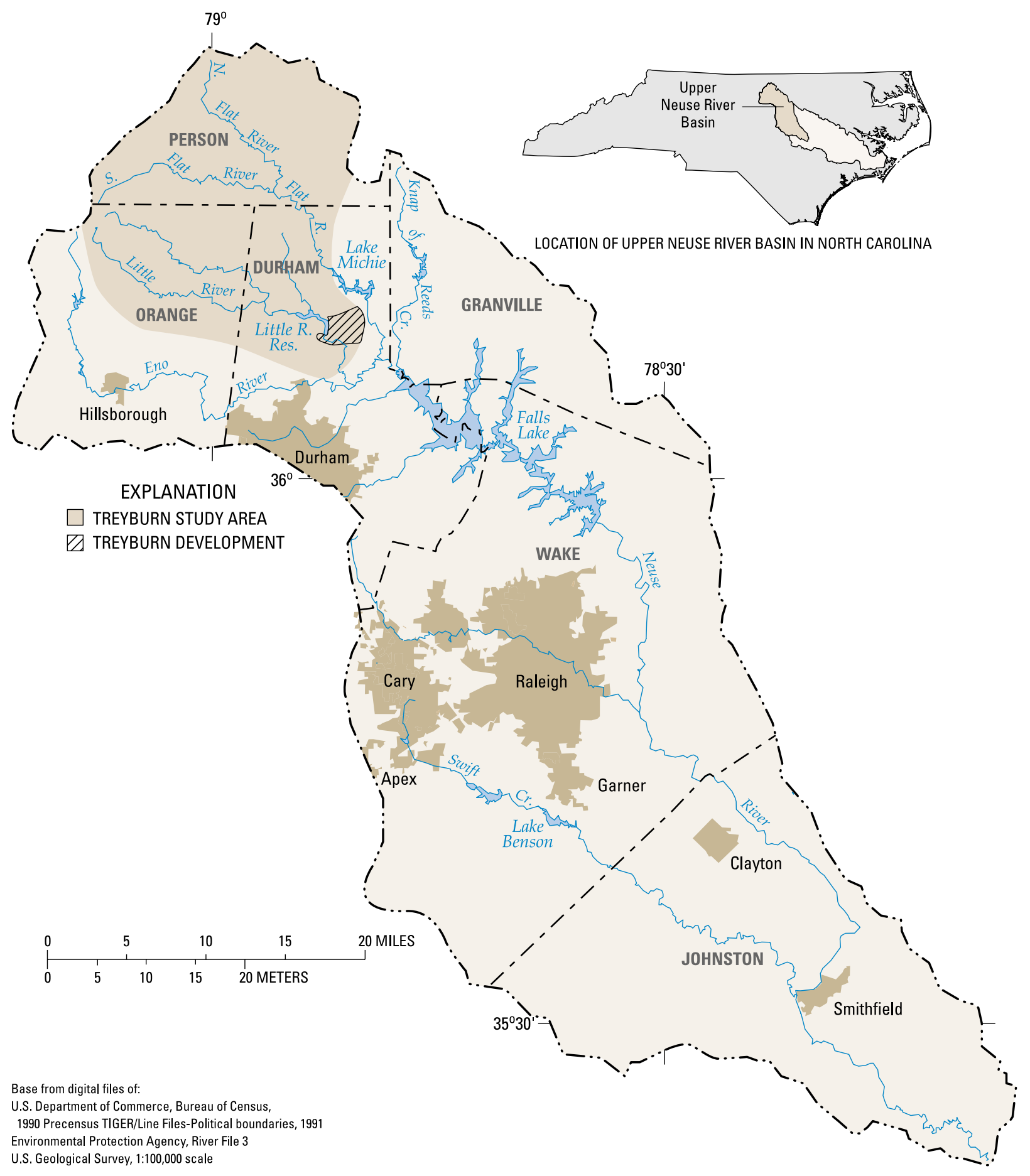

Figure 1. Location of the Treyburn development and study area in the upper Neuse River Basin, North Carolina.

land in the Treyburn development area is forested and abandoned farmland.

Three water-supply reservoirs lie just outside the Treyburn development boundaries-Lake Michie to the north, Falls Lake to the southeast, and Little River Reservoir to the west. The streams in the Treyburn area are classified as WS-IV, which means they are located in a moderately to highly developed water-supply watershed (North Carolina Division of Water Quality, 1992). All streams in the upper Neuse watershed are classified as nutrient-sensitive waters (NSW), which are subject to special nutrient-management regulations. In addition, 
much of the area in the Treyburn development also is classified as a water-quality critical area. A "critical area" is defined as a 0.5-mile-wide area that drains to water supplies from normal pool elevation of reservoirs or a 0.5 -mile-wide area that drains to a river intake (North Carolina Department of Environment, Health, and Natural Resources, 1993).

The WS-IV stream classification requires that buffer areas be left along perennial waters, no new landfills be allowed in the critical area, no new discharging landfills be located outside the critical area, no new sludge or petroleum-contaminated soils be applied in the critical area, and a hazardous-material containment plan and structure(s) be required for new industries in the area. Residential lots of 1 acre are allowed in the critical area, and 0.5-acre lots are allowed outside of the critical area. The North Carolina Division of Water Quality of the Department of Environment and Natural Resources (DENR) lists control of urban stormwater and protection of reservoirs among the priority issues for this part of the upper Neuse River Basin (North Carolina Department of Environment and Natural Resources, 1999).

Treyburn was designed to minimize the development's adverse effects on water quality. Because of the size of the development and its proximity to the water-supply reservoirs, however, local resource managers need to be able to quantify the effects of ongoing land-use conversion on water quality. In response to this need, the U.S. Geological Survey (USGS), in cooperation with the City of Durham, began a study in February 1988 to determine water-quality characteristics of surface waters in and around the Treyburn development area. Assessing water quality at a range of watershed scales and assisting local governments are among the primary activities that have been identified to meet the USGS mission (U.S. Geological Survey, 1999). Information was published previously for 17 sites that were monitored for all or part of the period February 1988 through September 1993 (Garrett and Bales, 1995). Since September 1995, five sites have been monitored in the study area.

\section{Purpose and Scope}

The purpose of this report is to characterize waterquality trends in selected streams flowing in or near the Treyburn development and identify nutrient and sediment loads at each site. The extent to which development affects water quality in Treyburn drainages also is described. An assessment of the condition of the benthic macroinvertebrate community at selected sites is presented. In addition, the channel geometry of selected streams in the Treyburn development is described to provide baseline data on physical stream characteristics and to relate those data to the condition of the benthic macroinvertebrate community. Data to characterize water quality, macroinvertebrate populations, and streamchannel characteristics in this report were collected during the period July 1994 through September 1998. Data for analysis of trends and to calculate constituent loads were collected at various times during the period October 1988 through September 1998.

\section{Study Area}

Treyburn is located north of the city of Durham in the Falls Lake watershed (fig. 1). The principal municipalities in the area are the cities of Durham and Raleigh. These cities had a combined total population of approximately 431,000 in 1998 (North Carolina Office of State Budget, Planning and Management, 1998). The combined population of these two cities increased approximately 24 percent between 1990 and 1998 .

Three water-supply reservoirs lie just outside the Treyburn development boundary (fig. 1). Lake Michie and the Little River Reservoir supply water to the city of Durham. Falls Lake, the largest of the three reservoirs, supplies water to the city of Raleigh. Most of the Treyburn development is drained by the Little River between the Little River Reservoir and the confluence of the Little River with the Eno River (fig. 1). Tributaries to the Flat River drain the eastern edge of the development. Thus, runoff from Treyburn development reaches Falls Lake through the Eno and Flat Rivers. The Treyburn development area constitutes approximately 1 percent of the total drainage area of Falls Lake. Lake Michie receives no drainage from the development, and the Little River Reservoir receives only minor runoff from the residential and undeveloped areas of Treyburn.

The climate of the study area is characterized by hot, humid summers, mild winters, and long growing seasons. The mean monthly temperature ranges from about 35 degrees Fahrenheit $\left({ }^{\circ} \mathrm{F}\right)$ in January to $80{ }^{\circ} \mathrm{F}$ in July. Precipitation in the study area averages about 45 inches per year (National Oceanic and Atmospheric Administration, 1988-92). The topography in the study area is gently sloping to moderately steep. The area is underlain primarily by slates as part of the Carolina slate belt. Granites underlie a portion of the Flat River Basin, and the soils in the area are predominantly well-drained, sandy loam (U.S. Department of Agriculture, Soil Conservation Service, 1976). 


\section{Land Use}

Treyburn consists of approximately 1,100 acres of residential, industrial, and recreational development, including a 210-acre golf course, and 4,300 acres of forested and abandoned agricultural areas (Garrett and Bales, 1995). At one time, the majority of the land in the development was cleared for agricultural use. As agricultural areas were abandoned, a mixed forest developed consisting mainly of oak, hickory, and pine trees.

In 1985, the major land uses in the Treyburn development area were approximately 15 percent agricultural and 85 percent mixed forest (Treyburn, Durham County, North Carolina, Zoning Application For A Mixed Land Use Project, written commun., 1986). Development in Treyburn has been slower than originally planned. In 1994, the land use in the Treyburn development area was approximately 20 percent residential, industrial, and recreational and approximately 80 percent mixed forest and abandoned agricultural lands. Treyburn originally was planned to be about 45 percent commercial development and about 20 percent residential development. Completion of the original development was planned for about 2006 (Treyburn, Durham County, North Carolina, Zoning Application For A Mixed Land Use Project, Appendix A, written commun., February 1986). In the Little and Flat River Basins upstream from Treyburn, the major land covers in 1988 were forested (approximately 55 percent) and agricultural and pasture (38 percent). The remainder was developed ( 7 percent; Childress and Bathala, 1997).

\section{Study Sites}

During the initial phase of the study (1988 through 1993; Garrett and Bales, 1995), 17 monitoring sites were active in or near the study area. As development in the area progressed, the focus of the monitoring network was narrowed to sites in areas that were most affected by landuse changes. In addition, a site in an undeveloped basin was retained for comparison. Five sites were selected to characterize the water quality from developed and undeveloped land uses in and near Treyburn (fig. 2; table 1). Flat River tributary upstream from site 1T drains an undeveloped area entirely within Treyburn that was planned primarily for commercial land use. Data from site $1 \mathrm{~T}$ provide a baseline for comparing the effects of developed areas. Little River tributary upstream from site $8 \mathrm{~T}$ drains a relatively small area that is densely developed with private, single-family residences and a golf course. Little River downstream from the Little River tributary at site 10TA characterizes the water quality of
Little River Reservoir and the forested and residential areas in the western part of the Treyburn development area.

Site 6T on Mountain Creek characterizes water quality from a moderately developing area where agricultural land use is being converted to urban land use. Mountain Creek is northwest of Treyburn and unaffected by development in Treyburn. Site 5T on Flat River at Bahama characterizes water quality in a more slowly developing area where agricultural land is being converted to forest (Childress and Bathala, 1997). This area also is unaffected by the Treyburn development.

Macroinvertebrate samples were collected at 10 sites. Six sites in addition to four of the water-quality monitoring sites were selected to provide an adequate number of sites in a range of watershed sizes (table 1). Eno River tributary (site 2T), Little River tributary (site 3T), and Little River tributary (site 8TB) drain small watersheds that are entirely within the Treyburn development. Little River near Orange Factory (site 4T) and Eno River near Weaver (site 11T) are large watersheds (table 1) that are entirely outside of the Treyburn development. Stream channel physical characteristics were measured at 8 sites, including 7 of the 10 sites where macroinvertebrate samples were collected.

\section{DATA COLLECTION}

From July 1994 through September 1998, streamflow and water-quality data were collected at five sites in or near the Treyburn study area (fig. 2; table 1). In February 1995, macroinvertebrate collections were obtained at 10 sites, and in February 1997, channel physical characteristics were measured at 8 sites (fig. 2; table 1). Data that were collected include continuous streamflow records; measurements of physical waterquality characteristics; analyses of concentrations of major dissolved ions, nutrients, metals and minor elements, and synthetic organic compounds; identification and enumeration of macroinvertebrates; and measures of stream-channel geomorphology.

\section{Streamflow Data}

Continuous streamflow record was collected at four sites to facilitate interpretation of water-quality data and to allow for calculation of nutrient loads. Stage was measured by using a pressure transducer and recorded at 15-minute intervals on an electronic data logger. A streamgaging station was installed at each site to house the equipment. Periodic measurements of stage and 


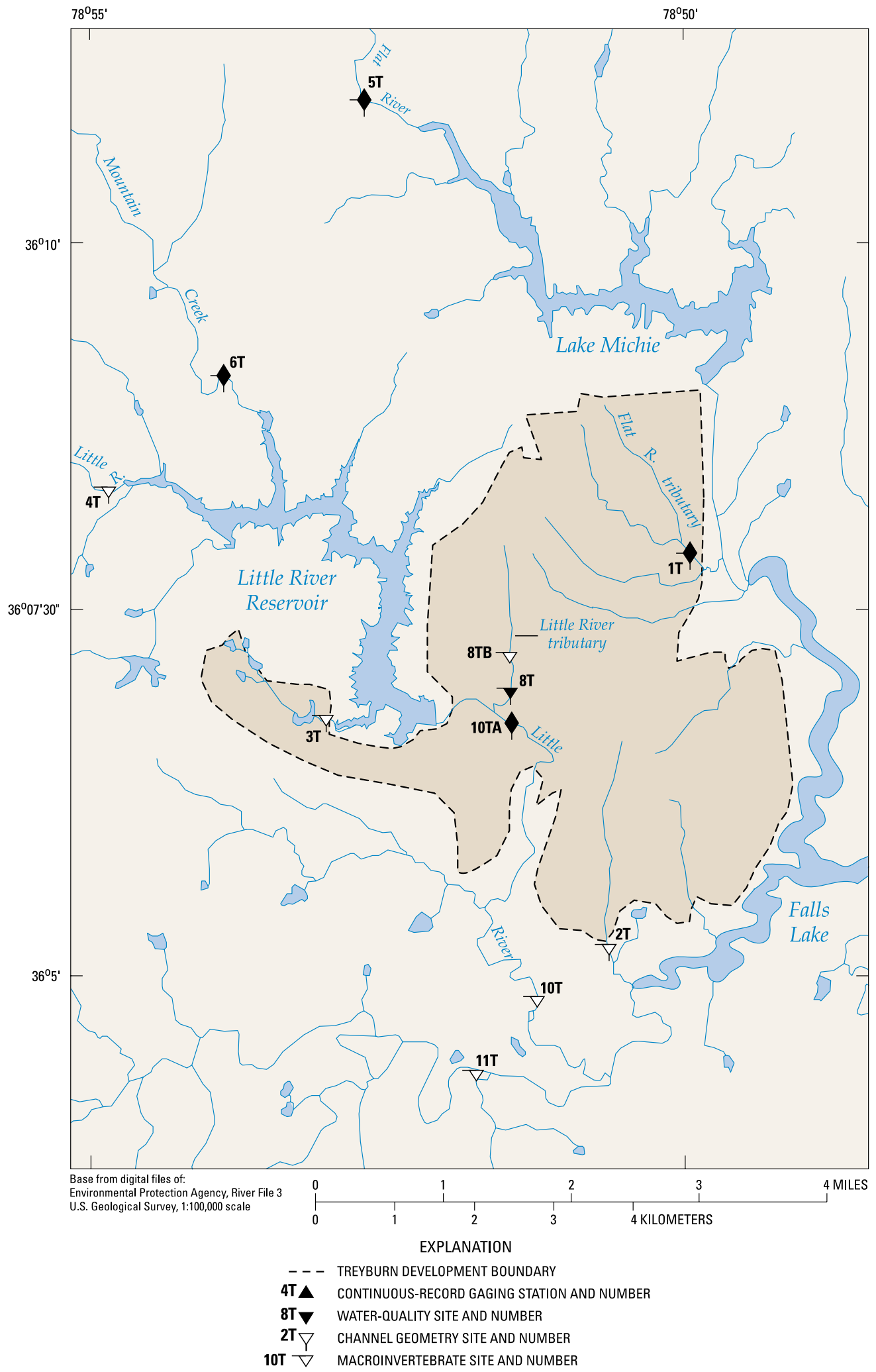

Figure 2. Locations of study sites in the Treyburn development area of North Carolina. 
Table 1. Data-collection sites in the Treyburn development study area, North Carolina

[USGS, U.S. Geological Survey; $\mathrm{mi}^{2}$, square mile; S, streamflow; Q, water quality; C, stream channel characteristics; M, macroinvertebrates; SR, secondary road; - , no data]

\begin{tabular}{|c|c|c|c|c|c|c|c|}
\hline \multirow[b]{2}{*}{$\begin{array}{l}\text { Site } \\
\text { no. } \\
\text { (fig. 2) }\end{array}$} & \multirow[b]{2}{*}{$\begin{array}{l}\text { USGS station } \\
\text { number }^{\mathrm{a}}\end{array}$} & \multirow[b]{2}{*}{ Site name } & \multirow[b]{2}{*}{$\begin{array}{l}\text { Drainage } \\
\text { area } \\
\left(\mathrm{mi}^{2}\right)\end{array}$} & \multirow[b]{2}{*}{$\begin{array}{l}\text { Type of data } \\
\text { collected }\end{array}$} & \multirow[b]{2}{*}{ Land cover } & \multicolumn{2}{|c|}{ Period of record } \\
\hline & & & & & & $\begin{array}{l}\text { Continuous } \\
\text { streamflow } \\
\text { record }\end{array}$ & $\begin{array}{l}\text { Water } \\
\text { quality }\end{array}$ \\
\hline $1 \mathrm{~T}$ & 0208650112 & $\begin{array}{l}\text { Flat River tributary near } \\
\text { Willardville }\end{array}$ & 1.14 & $\mathrm{~S}, \mathrm{Q}, \mathrm{C}, \mathrm{M}$ & Forested & $\begin{array}{r}3 / 88-9 / 90 \\
10 / 94-9 / 98\end{array}$ & $\begin{array}{l}1988-91 \\
1994-98\end{array}$ \\
\hline $2 \mathrm{~T}$ & 0208527100 & $\begin{array}{l}\text { Eno River tributary at SR } 1004 \\
\text { near Fairntosh }\end{array}$ & .57 & $\mathrm{C}, \mathrm{M}$ & Industrial & - & - \\
\hline $3 \mathrm{~T}$ & 0208524170 & $\begin{array}{l}\text { Little River tributary near } \\
\text { Durham }\end{array}$ & 1.02 & $\mathrm{C}, \mathrm{M}$ & Forest and residential & - & - \\
\hline $4 \mathrm{~T}$ & 0208521324 & $\begin{array}{l}\text { Little River at SR } 1461 \text { near } \\
\text { Orange Factory }\end{array}$ & 78.2 & $\mathrm{C}, \mathrm{M}$ & Forest and agricultural & - & - \\
\hline $5 \mathrm{~T}$ & 02085500 & Flat River at Bahama & 149 & $\mathrm{~S}, \mathrm{Q}, \mathrm{C}, \mathrm{M}$ & $\begin{array}{l}\text { Mixed forest and } \\
\text { agricultural }\end{array}$ & $7 / 25-9 / 98$ & $\begin{array}{l}1988-93 \\
1994-98\end{array}$ \\
\hline $6 \mathrm{~T}$ & 0208524090 & $\begin{array}{l}\text { Mountain Creek at SR } 1617 \text { near } \\
\text { Bahama }\end{array}$ & 8.00 & $\mathrm{~S}, \mathrm{Q}, \mathrm{C}, \mathrm{M}$ & $\begin{array}{l}\text { Mixed forest, } \\
\text { agricultural, and } \\
\text { residential }\end{array}$ & $10 / 94-9 / 98$ & $\begin{array}{l}1988-91 \\
1994-98\end{array}$ \\
\hline $8 \mathrm{~T}$ & 0208524950 & Little River tributary at Fairntosh & .86 & $\mathrm{~S}^{\mathrm{b}}, \mathrm{Q}, \mathrm{C}, \mathrm{M}$ & $\begin{array}{l}\text { Golf course and } \\
\text { residential }\end{array}$ & $-^{\mathrm{b}}$ & $1994-98$ \\
\hline $8 \mathrm{~TB}$ & 0208524930 & $\begin{array}{l}\text { Little River tributary } 0.3 \text { mile } \\
\text { above the mouth at Fairntosh }\end{array}$ & .60 & M & $\begin{array}{l}\text { Golf course and } \\
\text { residential }\end{array}$ & - & - \\
\hline $10 \mathrm{~T}$ & 02085262 & Little River near Weaver & 104 & M & $\begin{array}{l}\text { Mixed forest, } \\
\text { agricultural, and } \\
\text { residential }\end{array}$ & - & - \\
\hline 10TA & 0208524975 & $\begin{array}{l}\text { Little River below Little River } \\
\text { tributary at Fairntosh }\end{array}$ & 99.0 & $\mathrm{~S}, \mathrm{Q}, \mathrm{C}$ & $\begin{array}{l}\text { Mixed forest, } \\
\text { agricultural, and } \\
\text { residential/reservoir } \\
\text { outfall }\end{array}$ & $10 / 95-9 / 98$ & $1995-98$ \\
\hline $11 \mathrm{~T}$ & 02085079 & Eno River near Weaver & 148 & M & $\begin{array}{l}\text { Mixed forest and } \\
\text { residential }\end{array}$ & - & - \\
\hline
\end{tabular}

${ }^{\text {a }}$ Station number is assigned by the U.S. Geological Survey on the basis of geographic location. The downstream order number system is used for surface-water sites.

b Streamflow was measured only when a water-quality sample was collected.

instantaneous streamflow were used to develop a stagedischarge relation for calculating streamflow from continuous stage record (Rantz and others, 1982). Instantaneous streamflow measurements were made using a Price AA or pygmy current meter following standard USGS methods described by Rantz and others (1982). At site $8 \mathrm{~T}$, a gaging station could not be installed because of the proximity of the site to the Treyburn golf course. Thus, instantaneous streamflow measurements were made each time a water-quality sample was collected at this site (Rantz and others, 1982).

\section{Water-Quality Data}

Water-quality data were collected at five sites at regular intervals, approximately once per month, and during several storm events during water years 1994-981 (fig. 2; table 1). At Flat River tributary (site 1T) and Mountain Creek (site 6T), water-quality data also were collected at various frequencies, ranging from 3 to 11 times per year, during water years 1988-91 and at Flat River (site 5T) during water years 1988-93 (table 1). Samples were analyzed for nutrients and suspended sediment. Samples for analyses of synthetic organic compounds normally were collected once per year at low flow and twice per year during runoff conditions. Samples for analysis of metals and trace elements also were collected. Continuous streamflow was recorded at all water-quality sites except Little River tributary (site 8T).

\footnotetext{
${ }^{1}$ Water year is defined as the period October 1 through September 30 and is identified by the year in which it ends.
} 
Instantaneous streamflow was measured each time a sample was collected at Little River tributary.

\section{Field and Laboratory Methods}

Water-quality sample collection, handling, and analytical procedures for this study were the same as those described for the Triangle Area Water Supply Monitoring Project (Garrett and others, 1994) and comply with USGS standard procedures (Wilde and others, 1998). Stream samples for inorganic analysis were collected by using the depth-integrated, equal-width increment method; composited in a poly-carbonate churn splitter; and processed and preserved according to USGS standard operating procedures (Edwards and Glysson, 1988; Ward and Harr, 1990; Wilde and others, 1998). Water samples for analysis of dissolved constituents were filtered through a 0.45 -micron pore size membrane capsule filter. The samples were pumped through the filter with a peristaltic pump. Samples collected for organic analysis were collected in glass containers at midstream using either a weighted open-mouth sampler or by hand as a grab sample.

Water temperature, $\mathrm{pH}$, specific conductance, and dissolved oxygen were determined in the field at the time of sample collection. Field instruments were calibrated, and results were documented on a daily basis as part of the
USGS quality-assurance program. Also, as part of the quality-assurance program, equipment blank and duplicate samples were collected and analyzed on a routine basis (table 2).

Chemical analyses were performed by the USGS National Water Quality Laboratory in Denver, Colorado, by using established methods (Wershaw and others, 1987; Britton and Greeson, 1989; Fishman and Friedman, 1989; Fishman, 1993). Suspended-sediment concentrations were determined in the USGS sediment laboratories in Raleigh, North Carolina, and in Louisville, Kentucky, by using established methods and procedures (Guy, 1969).

Analytical procedures and lowest reporting levels for chemical constituents in water analyzed by the USGS National Water Quality Laboratory during this study are described by Garrett and others (1994).

\section{Quality-Assurance Samples}

Two types of quality-assurance samples were collected-replicates and blanks (table 2). Replicate samples were concurrent samples and split samples. Concurrent samples were collected as nearly simultaneously as possible to determine the replicability of the sampling technique. One of the concurrent samples was composited in a churn splitter and divided into two samples to produce split samples. These split samples

Table 2. Concentrations of nutrients in replicate and blank quality-assurance samples collected for the Treyburn development study [USGS, U.S. Geological Survey; N, nitrogen; P, phosphorus; <, less than; NA, not applicable; —, no data]

\begin{tabular}{|c|c|c|c|c|c|c|c|}
\hline \multirow[b]{2}{*}{$\begin{array}{l}\text { USGS gaging } \\
\text { station }^{\mathrm{a}} \text { and } \\
\text { site number } \\
\text { (fig. 2) }\end{array}$} & \multirow[b]{2}{*}{ Sample type } & \multirow[b]{2}{*}{$\begin{array}{c}\text { Sampling } \\
\text { date }\end{array}$} & \multicolumn{5}{|c|}{ Concentration, in milligrams per liter } \\
\hline & & & $\begin{array}{c}\text { Ammonia, } \\
\text { as N }\end{array}$ & $\begin{array}{c}\text { Ammonia plus } \\
\text { organic } \\
\text { nitrogen, } \\
\text { as N }\end{array}$ & $\begin{array}{c}\text { Nitrite } \\
\text { plus nitrate, } \\
\text { as N }\end{array}$ & $\begin{array}{c}\text { Total } \\
\text { phosphorus, } \\
\text { as P }\end{array}$ & $\begin{array}{l}\text { Orthophos- } \\
\text { phate, } \\
\text { as } P\end{array}$ \\
\hline 0208524090, site 6T & Concurrent/split & $4-6-95$ & $<0.015$ & $<0.2$ & 0.25 & $<0.01$ & $<0.01$ \\
\hline 0208524090 , site $6 \mathrm{~T}$ & Concurrent/split & $4-6-95$ & $<.015$ & .2 & .25 & $<.01$ & $<.01$ \\
\hline 0208524090, site $6 \mathrm{~T}$ & Concurrent & $4-6-95$ & $<.015$ & .2 & .25 & $<.01$ & $<.01$ \\
\hline 0208650112, site $1 \mathrm{~T}$ & Concurrent/split & $11-25-96$ & .02 & $<.2$ & .06 & $<.01$ & $<.01$ \\
\hline 0208650112, site $1 \mathrm{~T}$ & Concurrent/split & $11-25-96$ & .02 & $<.2$ & $<.05$ & $<.01$ & $<.01$ \\
\hline 0208650112, site 1T & Concurrent & $11-25-96$ & .02 & $<.2$ & .08 & $<.01$ & .02 \\
\hline NA & Blank & $8-13-96$ & $<.002$ & - & $<.005$ & - & $<.001$ \\
\hline NA & Blank & $11-24-96$ & $<.002$ & - & $<.005$ & - & $<.001$ \\
\hline NA & Blank & 1-13-97 & $<.002$ & - & $<.005$ & - & $<.001$ \\
\hline NA & Blank & $3-10-97$ & $<.002$ & - & $<.005$ & - & $<.001$ \\
\hline NA & Blank & $4-28-97$ & $<.002$ & - & .005 & - & .003 \\
\hline NA & Blank & $9-16-97$ & $<.002$ & - & $<.005$ & - & $<.001$ \\
\hline NA & Blank & $10-28-97$ & $<.002$ & - & $<.005$ & - & .002 \\
\hline NA & Blank & $3-9-98$ & $<.002$ & - & $<.005$ & - & .001 \\
\hline
\end{tabular}


were used to determine the repeatability of sample analyses by the USGS National Water Quality Laboratory. With this procedure, three replicate qualityassurance samples were produced - a concurrent replicate, and from the second concurrent replicate, two split samples referred to as concurrent/split in table 2 . Samples containing water certified as inorganic blank water were processed onsite to determine if equipment cleaning or sample-processing procedures resulted in contamination by any of the compounds of interest. Blank samples generally were analyzed at reporting levels that were about an order of magnitude less than reporting levels for the environmental samples.

Nutrient concentrations in split- and concurrentreplicate samples are shown in table 2. Split sample results were within 0.01 milligram per liter $(\mathrm{mg} / \mathrm{L})$, indicating good analytical repeatability. Concurrentreplicate sample concentrations also were within $0.01 \mathrm{mg} / \mathrm{L}$ except for nitrite plus nitrate, which was within $0.03 \mathrm{mg} / \mathrm{L}$, indicating that the sampling method also had good repeatability.

Blank samples were analyzed for nutrients (table 2) and metals (table 3). Concentrations in blank samples generally were at or below the reporting level. The reporting level for blank samples was about an order of magnitude lower than the reporting level for environmental samples. Concentrations for metals in blank samples also were at or below the reporting level except for aluminum, copper, manganese, and zinc (table 3). One blank sample was contaminated with traces of these constituents, presumably from equipment. However, the level of contamination was far below the reporting level for environmental samples. Contamination at this level would not affect the analysis of environmental samples.

\section{Benthic Macroinvertebrates}

Benthic macroinvertebrate samples were collected at 10 sites on the Eno River, Flat River, Little River, Mountain Creek, and their tributaries (fig. 2). Methods of the USGS National Water-Quality Assessment (NAWQA) Program (Cuffney and others, 1993) were used to collect three types of samples at each site: (1) a semiquantitative sample from the habitat expected to support the richest invertebrate assemblage (richest targeted habitat, or RTH sample), (2) a semiquantitative sample from a depositional habitat (depositional targeted habitat, or DTH sample) where exposure to sedimentborne contaminants is expected to be greatest, and (3) a qualitative sample from all accessible habitats at a site (qualitative multihabitat, or QMH sample). RTH samples were collected from riffles by using a Slack sampler with a 425-micron mesh net at all sites except at site 10T, which lacked riffle habitat. RTH samples at site 10T were collected from wood snags by using the Slack sampler. DTH samples were collected from pools by using a 7-centimeter-diameter core sampler at all sites except at sites $1 \mathrm{~T}$ and $11 \mathrm{~T}$ where a petite Ponar was used. QMH samples were collected by using a D-frame net with 210-micron mesh along with hand picking of invertebrates from leaves, wood, and rocks. Bias toward any one habitat in QMH collections was minimized by equalizing the sample effort (time) for each habitat type.

Samples were preserved in ethyl alcohol and sent to the North Carolina Division of Water Quality (NCDWQ) for enumeration and identification (David Lenat, North Carolina Division of Water Quality, written commun., 1995). The NCDWQ processed all samples quantitatively (that is, provided data on the abundance of each taxon in each sample). Samples with large numbers

Table 3. Reporting levels for environmental and blank samples, and concentrations of metals in blank quality-assurance samples collected for the Treyburn development study

[NA, not applicable; <, less than]

\begin{tabular}{|c|c|c|c|c|c|c|c|c|c|c|c|c|}
\hline \multirow[b]{2}{*}{$\begin{array}{l}\text { Sampling } \\
\text { date }\end{array}$} & \multicolumn{12}{|c|}{ Concentration, in micrograms per liter } \\
\hline & $\begin{array}{c}\text { Alumi- } \\
\text { num }\end{array}$ & $\begin{array}{l}\text { Cadmi- } \\
\text { um }\end{array}$ & $\begin{array}{l}\text { Chro- } \\
\text { mium }\end{array}$ & Cobalt & Copper & Iron & Lead & $\begin{array}{l}\text { Manga- } \\
\text { nese }\end{array}$ & $\begin{array}{l}\text { Molyb- } \\
\text { denum }\end{array}$ & Nickel & Silver & Zinc \\
\hline & \multicolumn{12}{|c|}{ Lowest reporting level for environmental samples } \\
\hline \multirow[t]{2}{*}{ NA } & $<10$ & $<1$ & $<1$ & $<1$ & $<1$ & $<20$ & $<1$ & $<1$ & $<1$ & $<1$ & $<1$ & $<10$ \\
\hline & \multicolumn{12}{|c|}{ Lowest reporting level for blank samples } \\
\hline \multirow[t]{2}{*}{ NA } & $<.3$ & $<.3$ & $<.2$ & $<.2$ & $<.2$ & $<.3$ & $<.3$ & $<.1$ & $<.2$ & $<.5$ & $<.2$ & $<.5$ \\
\hline & \multicolumn{12}{|c|}{ Results of analyses of blank samples } \\
\hline $11-24-96$ & $<.3$ & $<.3$ & $<.2$ & $<.2$ & $<.2$ & $<.3$ & $<.3$ & $<.1$ & $<.2$ & $<.5$ & $<.2$ & $<.5$ \\
\hline $1-13-97$ & $<.3$ & $<.3$ & $<.2$ & $<.2$ & $<.2$ & $<.3$ & $<.3$ & $<.1$ & $<.2$ & $<.5$ & $<.2$ & $<.5$ \\
\hline $10-28-97$ & .61 & $<.3$ & $<.2$ & $<.2$ & .86 & $<.3$ & $<.3$ & .11 & $<.2$ & $<.5$ & $<.2$ & .65 \\
\hline $3-9-98$ & $<.3$ & $<.3$ & $<.2$ & $<.2$ & $<.2$ & $<.3$ & $<.3$ & $<.1$ & $<.2$ & $<.5$ & $<.2$ & .67 \\
\hline
\end{tabular}


of invertebrates were subsampled (quartered), whereas smaller samples (DTH) were processed in their entirety (North Carolina Department of Environment and Natural Resources, 1997b).

In addition to processing samples, the NCDWQ rated the water-quality conditions at the 10 sites based on the North Carolina Biotic Index (NCBI; Lenat, 1988). The NCBI is based on the abundance-weighted average tolerance value for taxa in a sample:

$$
\mathrm{NCBI}=\frac{\sum_{i=1}^{N}\left(T V_{i}\right) \times n_{i}}{\sum_{i=1}^{N} n_{i}},
$$

where:

$T V_{i}$ is the tolerance value for species $i$. Tolerance values range from zero (indicative of the best water quality) to 10 (indicative of the worst water quality).

$n_{i}$ is an abundance value $(1,3$, or 10$)$ that describes how abundant the organism is in the sample. Rare organisms (1-2 specimens in a sample) are assigned an abundance value of 1 ; common organisms (3-9 specimens in a sample) are assigned an abundance value of 3 ; abundant organisms (10 or more organisms in a sample) are assigned an abundance value of 10.

$N$ is the number of taxa in the sample for which a tolerance value has been derived.

The taxa-specific tolerance values are based on the relation between a taxon's distribution and water-quality conditions compiled by the NCDWQ over the past 10 to 15 years. The NCBI may range from zero to 10 with lower numbers indicating better water-quality conditions. The NCDWQ uses the NCBI and other assemblage metrics (for example, the EPT metric is based on numbers of Ephemeroptera (mayflies), Plecoptera (stoneflies), and Trichoptera (caddis flies) - groups that are intolerant of stream pollutants) to rate water-quality conditions as poor, fair, fair-good, good, or excellent. These ratings are based on a composite of the samples collected at each site (RTH, DTH, and QMH). Patterns in the distribution of invertebrates among sites were explored by using ordination (detrended correspondence analysis), and these patterns were related to patterns in physical and chemical site characteristics by using indirect gradient analysis (ter Braak, 1987).

\section{Stream Geometry}

Channel geometry was assessed at eight sites in February 1997 (fig. 2; table 1). Site locations were selected to (1) coincide with sites having previous waterquality data collections, (2) represent the range of land uses in the study area, and (3) provide fairly even spatial distribution throughout the study area. A section of stream, referred to as a stream reach (Fitzpatrick and others, 1998), was identified at each site. The length of stream reach at each site was about 20 times the channel width. The distance is considered to generally represent at least one complete stream meander wavelength (Leopold and others, 1964). Incorporating at least one complete meander wavelength within the area of study is important, as most channel responses tend to be represented within a stream-channel meander.

Before surveying was conducted, the locations of benchmarks near each site were established by using data provided by registered land surveyors (Larry Poole and Associates, P.A., Durham, North Carolina, oral commun., July 1994). At each site, at least three points along the reach were selected for cross-section measurement. Locations of cross sections to be surveyed were selected to represent prominent geomorphic features, such as meander bends and point bars.

Stream cross-section location and elevation data were collected by using the Pentx PTS III05 total station survey instrument and the SC_5 data collector. At each stream site, two reference points were established to conduct the survey and to re-create the survey in the future. Three or four cross-channel profiles were surveyed along each stream reach.

Surveyed angles and distances were processed by using ARC/INFO software (Environmental Systems Research Institute, 1992). For each reach, data sets were produced that contained digital map representations of the linear and areal features surveyed, as well as point locations. Specific linear features known as routes were included in the data sets to define the cross-section stations relative to the left and right banks and water edge. Stationing and elevation coordinates were processed to compute cross sectional area for surveyed conditions and estimated bankfull conditions.

Data for several stream characteristics were derived from cross-section information. Because erosion and sediment transport are most active when streamflow is near bankfull (Leopold, 1994), determination of the bankfull width of a stream is important. Bankfull width is 
the width of channel where the water level just begins to overflow the channel into the active flood plain (Emmett, 1975). The flood plain is defined as the nearly level area adjacent to the channel and constructed by the stream in the present climatic and hydrologic regime (Leopold, 1994). Bank height is defined as the difference between the elevation of the flood plain and the elevation of the channel bed. Bank angles were determined from horizontal at the elevation of the water surface to the top of the bank (Fitzpatrick and others, 1998). Average depths were computed by dividing cross sectional area by bankfull width. Channel gradient was calculated by using elevation data from the upstream-most and downstreammost cross sections.

\section{STREAMFLOW CONDITIONS}

Streamflow conditions for water years 1989-98 were compared to long-term mean discharge (1925-98) to provide a context for assessing constituent loads. This comparison is illustrated in a histogram of mean monthly streamflow at the Flat River at Bahama streamgage (site 5T, fig. 3). Higher than average streamflow occurred during 1989, 1993, 1996, and 1998 when monthly means were more than double the normal monthly mean streamflow during at least 2 months of the year. In September 1996, Hurricane Fran resulted in a monthly mean that was more than two orders of magnitude greater than the September long-term mean. Rainfall amounts in

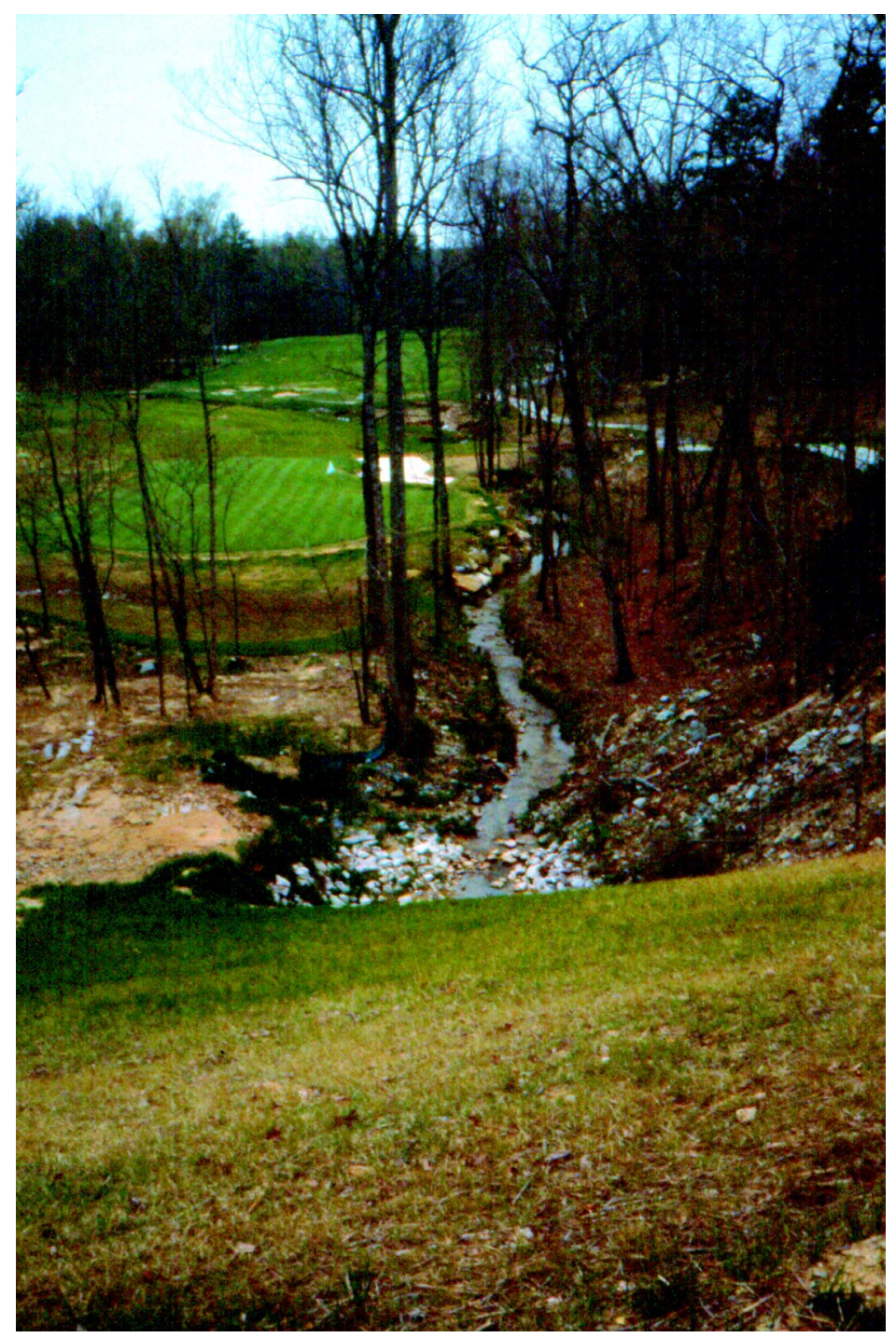

Little River tributary draining the Treyburn Golf Course. 


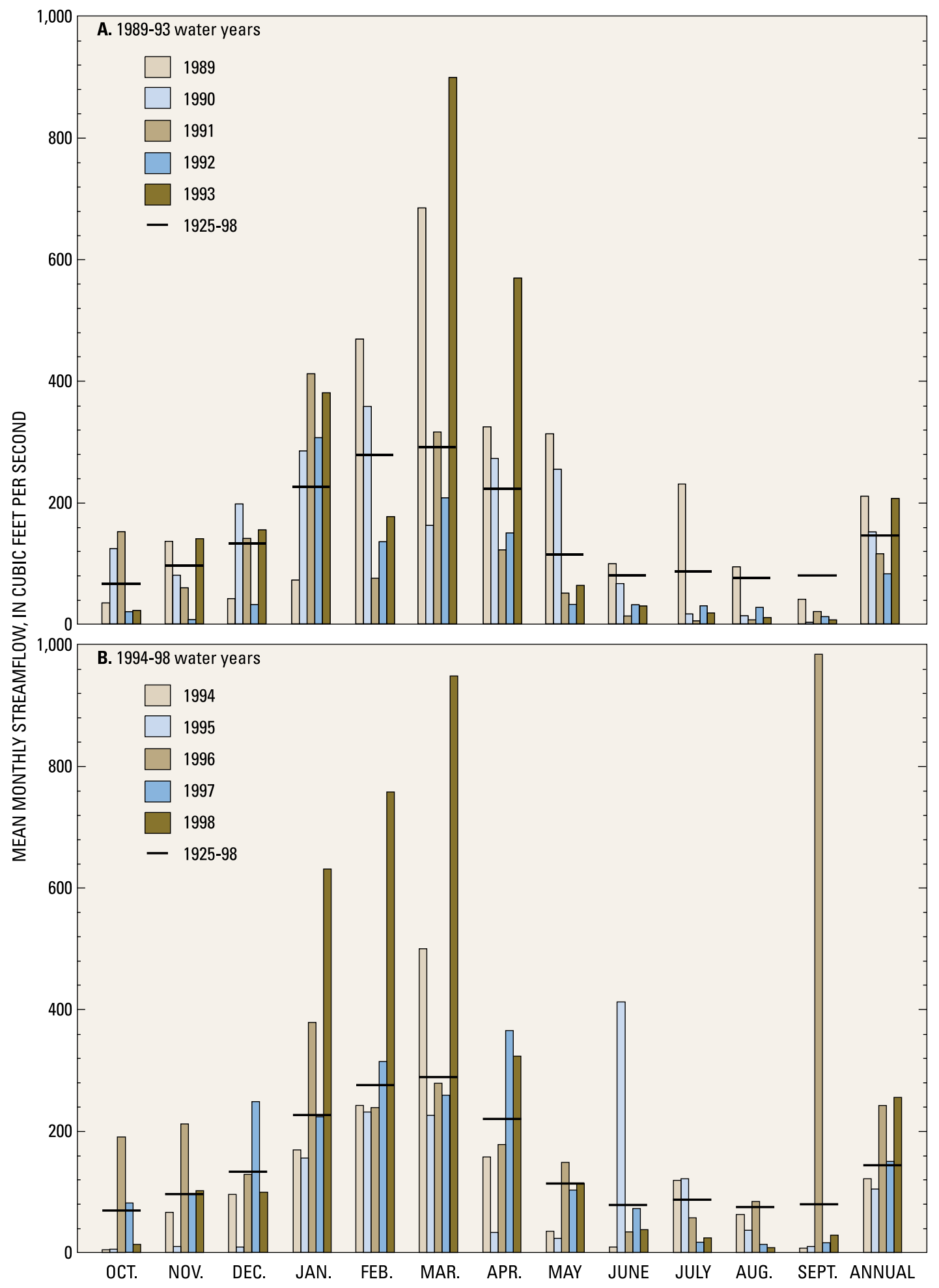

Figure 3. Mean monthly streamflow for (A) water years 1989-93 and (B) water years 1994-98 and long-term mean monthly streamflow (1925-98) at the Flat River at Bahama, North Carolina. 
1996 and 1998, as well as in 1995, exceeded the long-term mean (fig. 4). At Flat River at Bahama, the peak streamflow from Hurricane Fran exceeded the 500-year recurrence interval for that site (Bales and Childress, 1996). At each gage site, the peak discharge of record occurred on September 6, 1996, after the passage of Hurricane Fran. Average or lower than average streamflow occurred during most of 1992, 1994, and 1995 (at least 9 of 12 months; fig. 3). Streamflow during 1990 and 1997 was near the long-term mean.

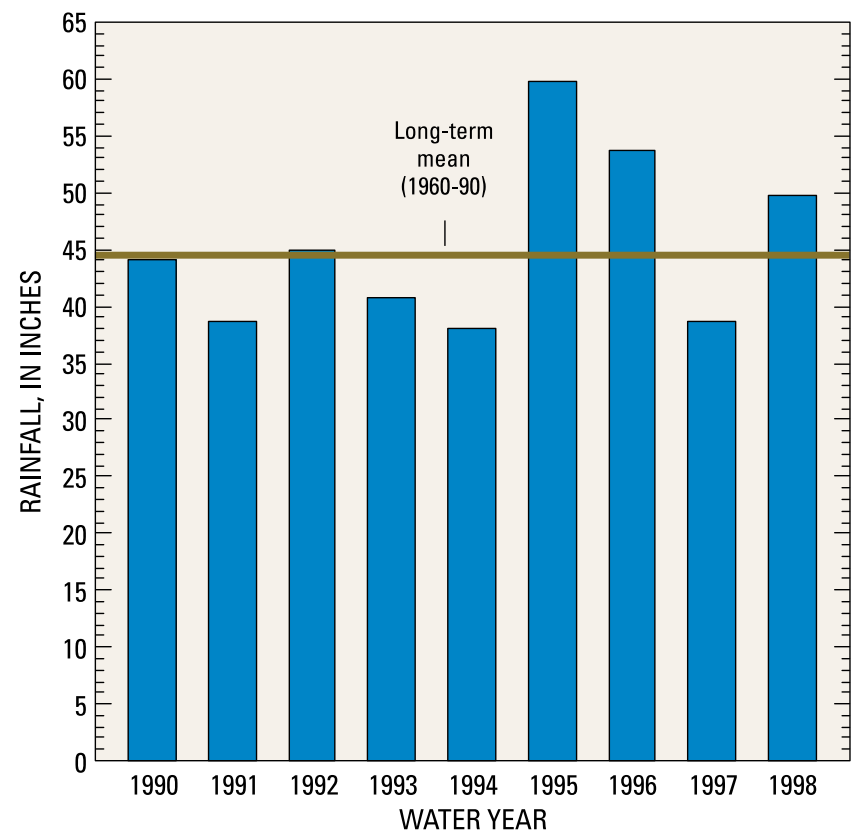

Figure 4. Annual rainfall amounts for water years 1990-98 and long-term mean annual rainfall (1960-90) at a National Oceanic and Atmospheric Administration site in northern Wake County, North Carolina.
The mean annual runoff at each of the gaged sites ranged from 13.22 to 15.86 inches (in.), or 0.97 to 1.17 cubic feet per second per square mile $\left(\left[\mathrm{ft}^{3} / \mathrm{s}\right] / \mathrm{mi}^{2}\right.$; table 4). Estimates of runoff for Little River (site 10TA), Flat River tributary (site 1T), and Mountain Creek (site 6T) are based on 3 to 12 years of record that includes significantly above-normal rainfall in 1995 and 1996 (fig. 4). Mean annual runoff for Flat River at Bahama (site $5 \mathrm{~T} ; 13.22 \mathrm{in}$.) is a long-term mean based on 74 years of record and probably is a better estimate.

Continuous streamflow record was unavailable for the Little River tributary (site 8T). Instantaneous measurements of discharge at this site were compared with the discharge record for the same date and time at Flat River tributary (site 1T; fig. 5). Flat River tributary is gaged, is of similar drainage-basin size (table 1), and is within less than 2 miles (mi) of Little River tributary so that rainfall reasonably can be assumed to be similar (fig. 2).

Although the Little River tributary drainage area is about 75 percent of the Flat River tributary drainage area, Little River tributary streamflow is about 84 percent of the Flat River tributary streamflow $\left(r^{2}=0.83\right)$. Scatter about the regression line (fig. 5B) was greatest when streamflow was less than about $0.5 \mathrm{ft}^{3} / \mathrm{s}$, indicating that streamflow during low-flow periods, when runoff from golf-course irrigation supplements natural flow in the Little River tributary, may be underestimated. Flat River tributary does not receive irrigation flows. For this report, streamflow was used to calculate water-quality loads, the least significant portions of which are contributed during low-flow periods.

For the purposes of load calculation, it is essential that sampling covers a complete range of streamflow

Table 4. Streamflow characteristics for gaged sites in the Treyburn development study area [USGS, U.S. Geological Survey; SR, secondary road]

\begin{tabular}{|c|c|c|c|c|c|}
\hline $\begin{array}{l}\text { USGS gaging } \\
\text { station and } \\
\text { site number } \\
\text { (fig. 2) }\end{array}$ & Site name & $\begin{array}{l}\text { Drainage area, } \\
\text { in square miles }\end{array}$ & $\begin{array}{c}\text { Period of } \\
\text { record } \\
\text { (water years) }\end{array}$ & $\begin{array}{c}\text { Mean annual runoff, } \\
\text { in cubic feet per second } \\
\text { per square mile }\end{array}$ & $\begin{array}{l}\text { Mean annual runoff, } \\
\text { in inches }\end{array}$ \\
\hline $\begin{array}{l}0208524090 \\
\text { site } 6 \mathrm{~T}\end{array}$ & $\begin{array}{l}\text { Mountain Creek at SR } 1617 \text { near } \\
\text { Bahama }\end{array}$ & 8.00 & $1995-98$ & 1.17 & 15.86 \\
\hline $\begin{array}{l}0208524975 \\
\text { site 10TA }\end{array}$ & $\begin{array}{l}\text { Little River below Little River } \\
\text { tributary at Fairntosh }\end{array}$ & 99.0 & $1996-98$ & 1.13 & 15.33 \\
\hline $\begin{array}{l}02085500 \\
\text { site } 5 \mathrm{~T}\end{array}$ & Flat River at Bahama & 149 & $1925-98$ & .97 & 13.22 \\
\hline $\begin{array}{l}0208650112 \\
\text { site 1T }\end{array}$ & $\begin{array}{l}\text { Flat River tributary near } \\
\text { Willardville }\end{array}$ & 1.14 & $\begin{array}{l}1988-90 \\
1995-98\end{array}$ & 1.13 & 15.36 \\
\hline
\end{tabular}



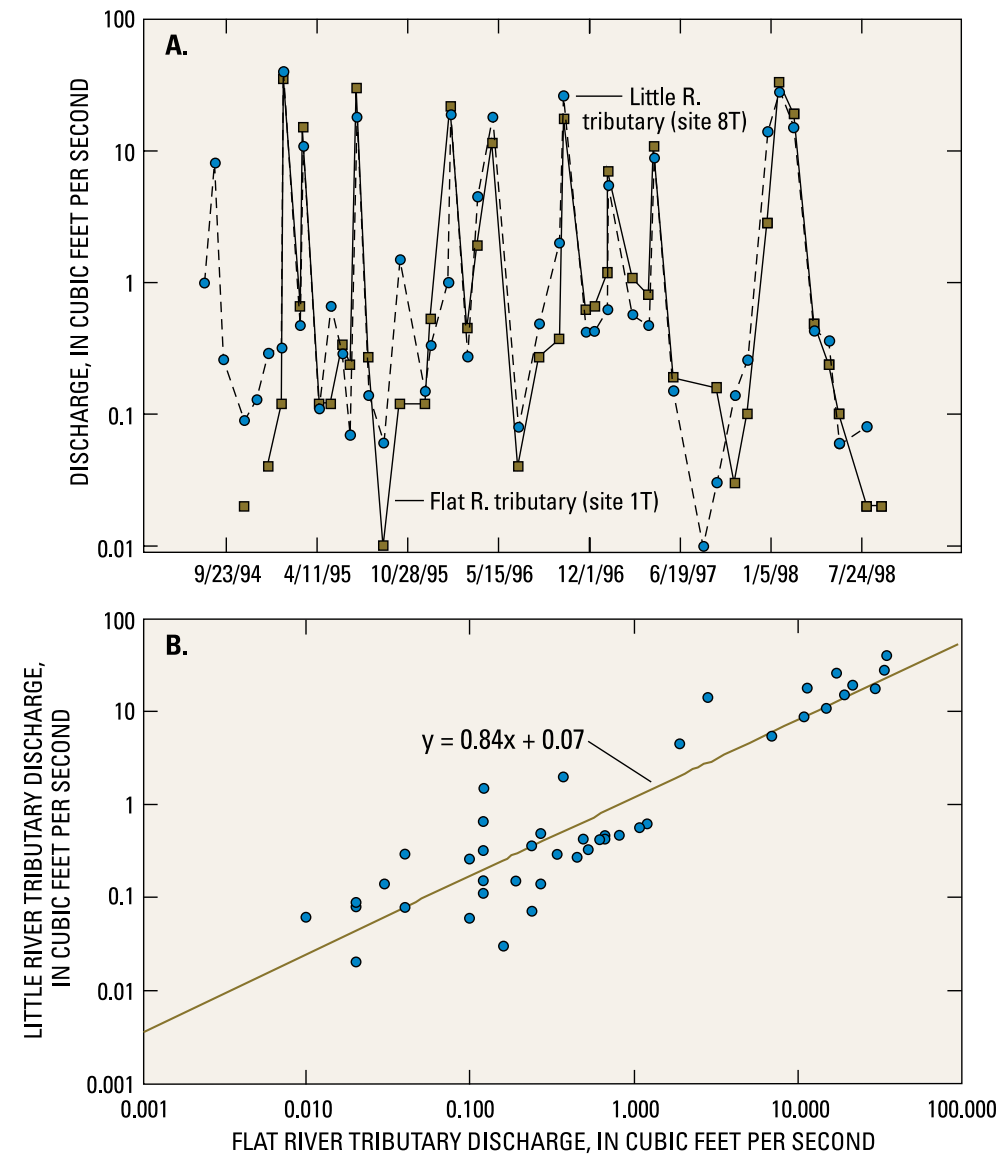

Figure 5. (A) Instantaneous discharge measurements at Flat River and Little River tributaries, 1994-98, and (B) relation between discharges at Flat River and Little River tributaries in the Treyburn development study area, North Carolina.

conditions, as concentration often varies significantly with changes in streamflow. Flow frequency based on continuous streamgage record was compared to flow frequency of instantaneous discharges during which water-quality samples were collected to determine if the range of flows sampled was representative of the range of flows that occurred at each site. This analysis also was used to determine if the highest flow sampled corresponded with the highest recorded flow. The range of sampled flows corresponded well with flow frequencies (fig. 6). Flat River tributary has the smallest drainage-basin size (table 4), and low-flow periods were somewhat underrepresented at site 1T. At each site, the highest sampled flow exceeded the 99th-percentile flow. The peak instantaneous discharge of record at each site occurred during runoff from Hurricane Fran on September 6, 1996, and was not sampled (fig. 7). 

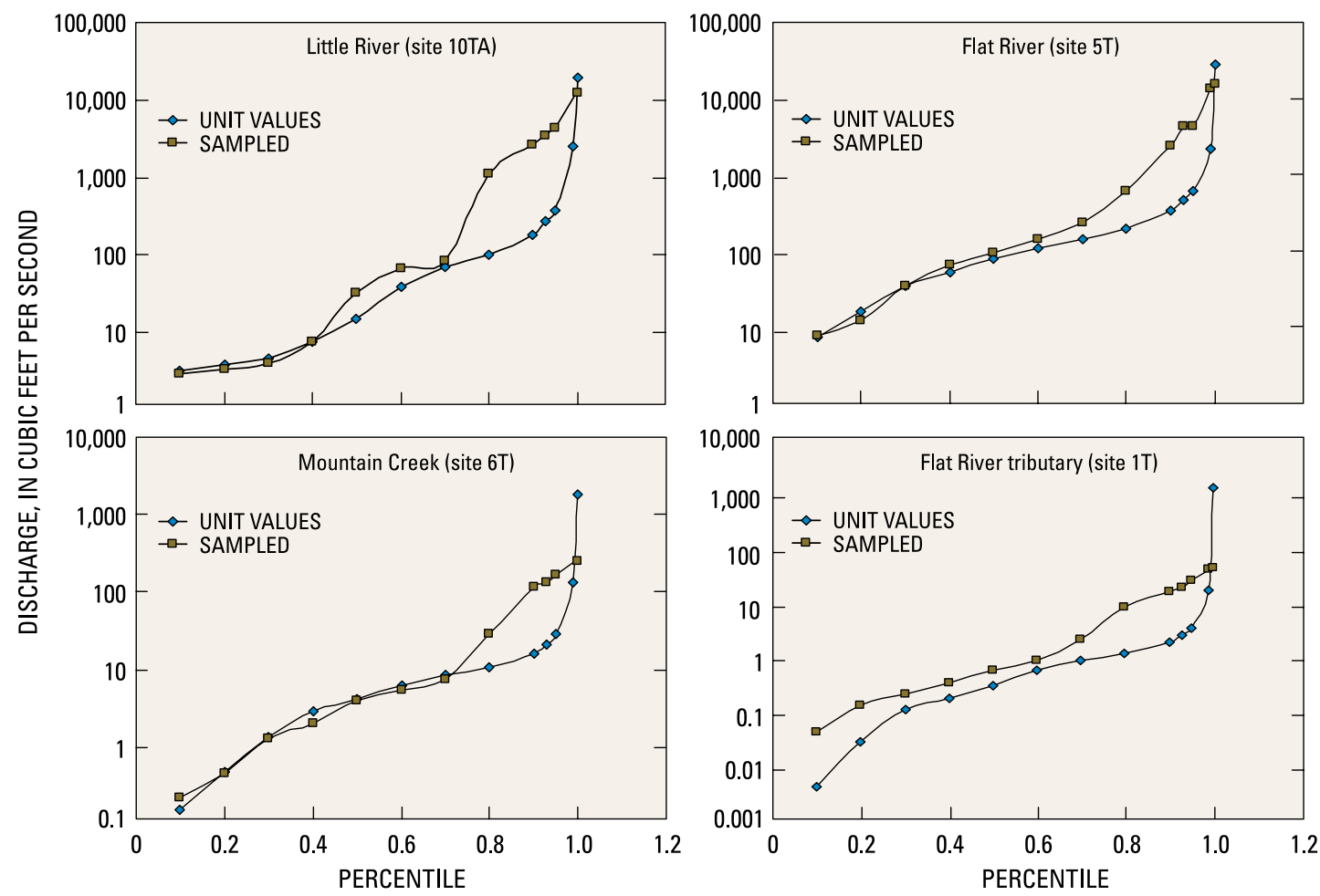

Figure 6. Long-term discharge frequency and instantaneous discharge frequency for sampled discharges at gaged water-quality sites in the Treyburn development study area, North Carolina.
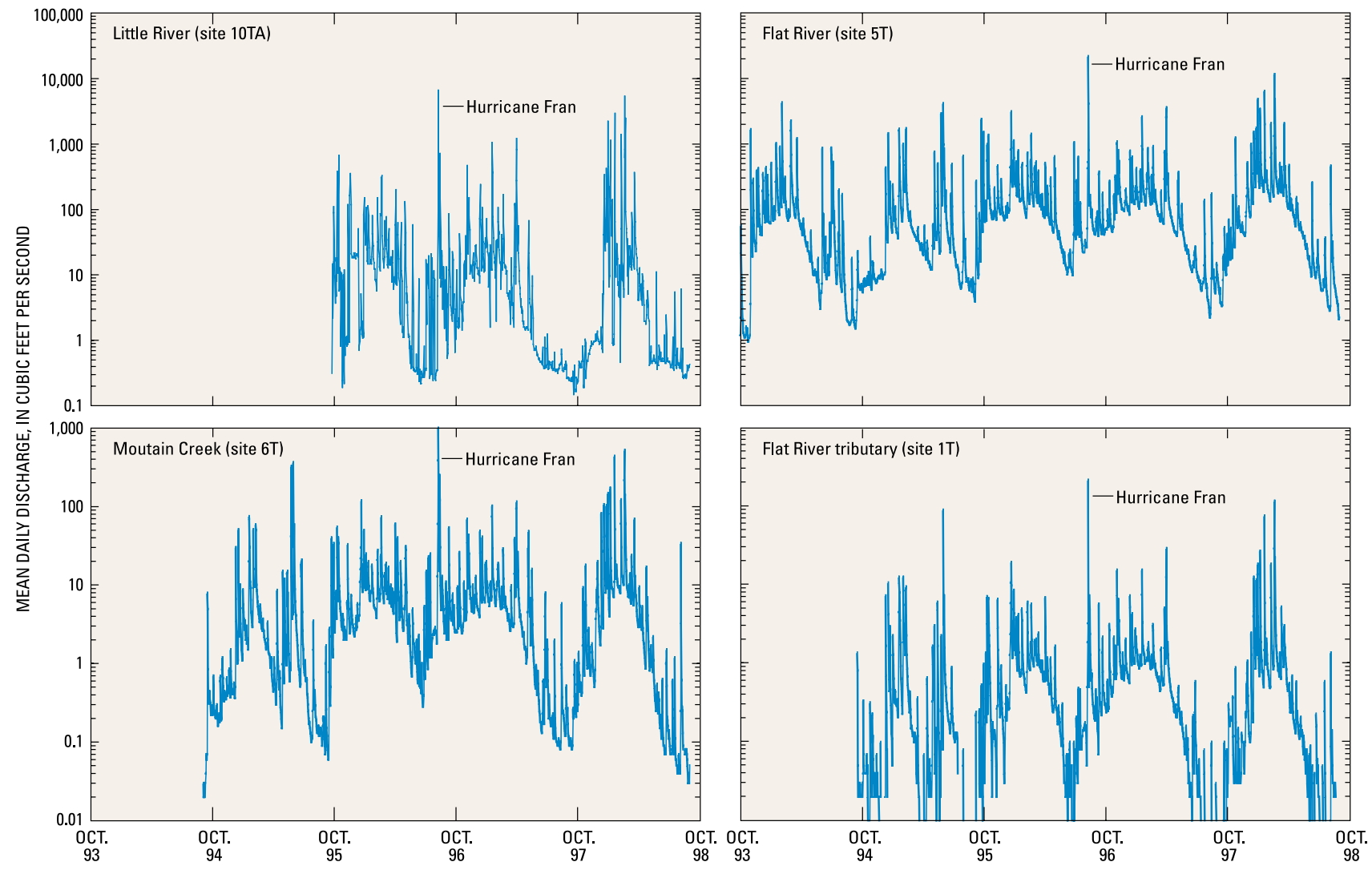

Figure 7. Discharge for water years $1994-98$ at Little River below Little River tributary at Fairntosh (site 10TA), Flat River at Bahama (site 5T), Mountain Creek (site 6T), and Flat River tributary (site 1T). 


\section{STREAM PHYSICAL CHARACTERISTICS}

Stream channels are dynamic features that adjust to changing environmental conditions. A stream's ability to adjust is a function of such factors as discharge, channel gradient, and sediment transport (Gordon and others, 1992). Natural or manmade changes to these factors along a stream result in channel adjustments for some distance upstream and downstream in order to offset such changes. Examining channel response is not only important to understanding the effects of channel alterations, such as bridges, but also is critical to understanding the relations among physical stream features and aquatic biota of a stream.

An understanding of channel response requires baseline data on channel geometry, such as those collected for this study. These baseline data and future measures of channel geometry will provide the opportunity to describe changes in channel dimensions consistently and repeatedly. Descriptions of stream cross sections in space and time help to define patterns in channel adjustments and quantitative assessments of channel shape.

Channel geometry was assessed at eight sites in February 1997 (table 1; fig. 2). Examination of mean bank angle and mean channel width-to-depth ratios indicated that the sites could be separated into three groups: (1) sites 1T, 2T, and 8T, which have mean bank angles greater than 40 degrees and width-to-depth ratios less than 10; (2) sites 3T, 6T, and 10TA, which have mean bank angles less than 40 degrees and width-to-depth ratios from 10 to 20; and (3) sites $4 \mathrm{~T}$ and 5T, which have mean bank angles less than 40 degrees and width-to-depth ratios greater than 20 (fig. 8). At sites 1T, 2T, and 8T, individual measures of bank angle were 60 degrees or greater (fig. 9).

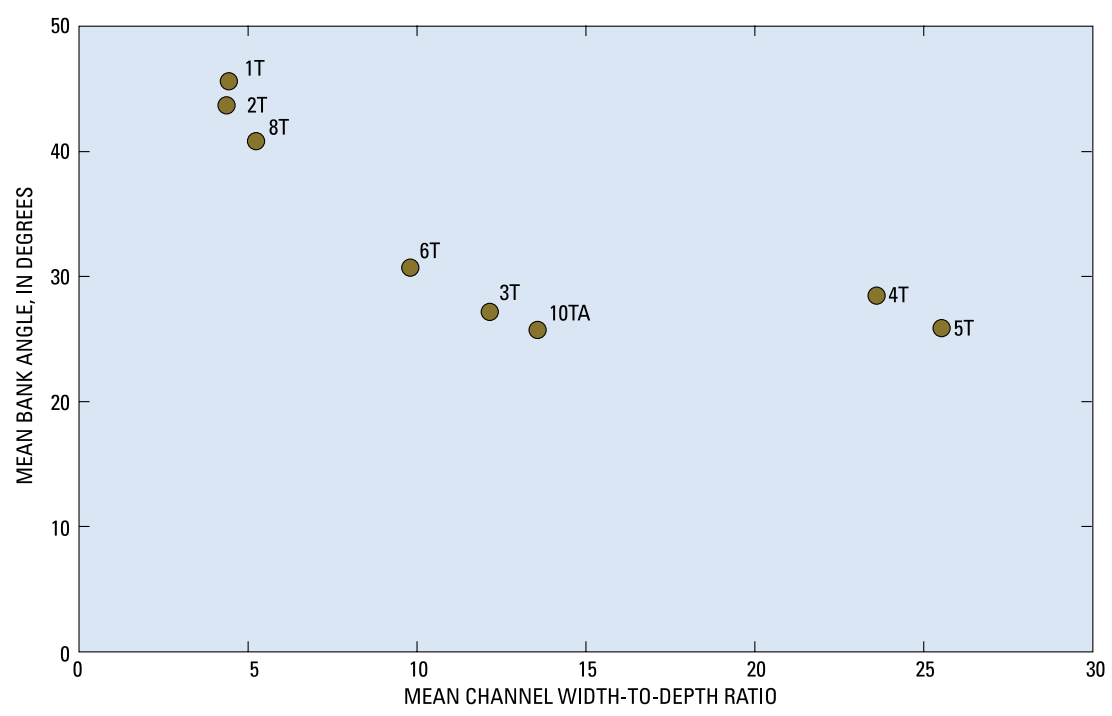

Figure 8. Relation between mean bank angle and mean channel width-to-depth ratio for sites in the Treyburn development study area. 


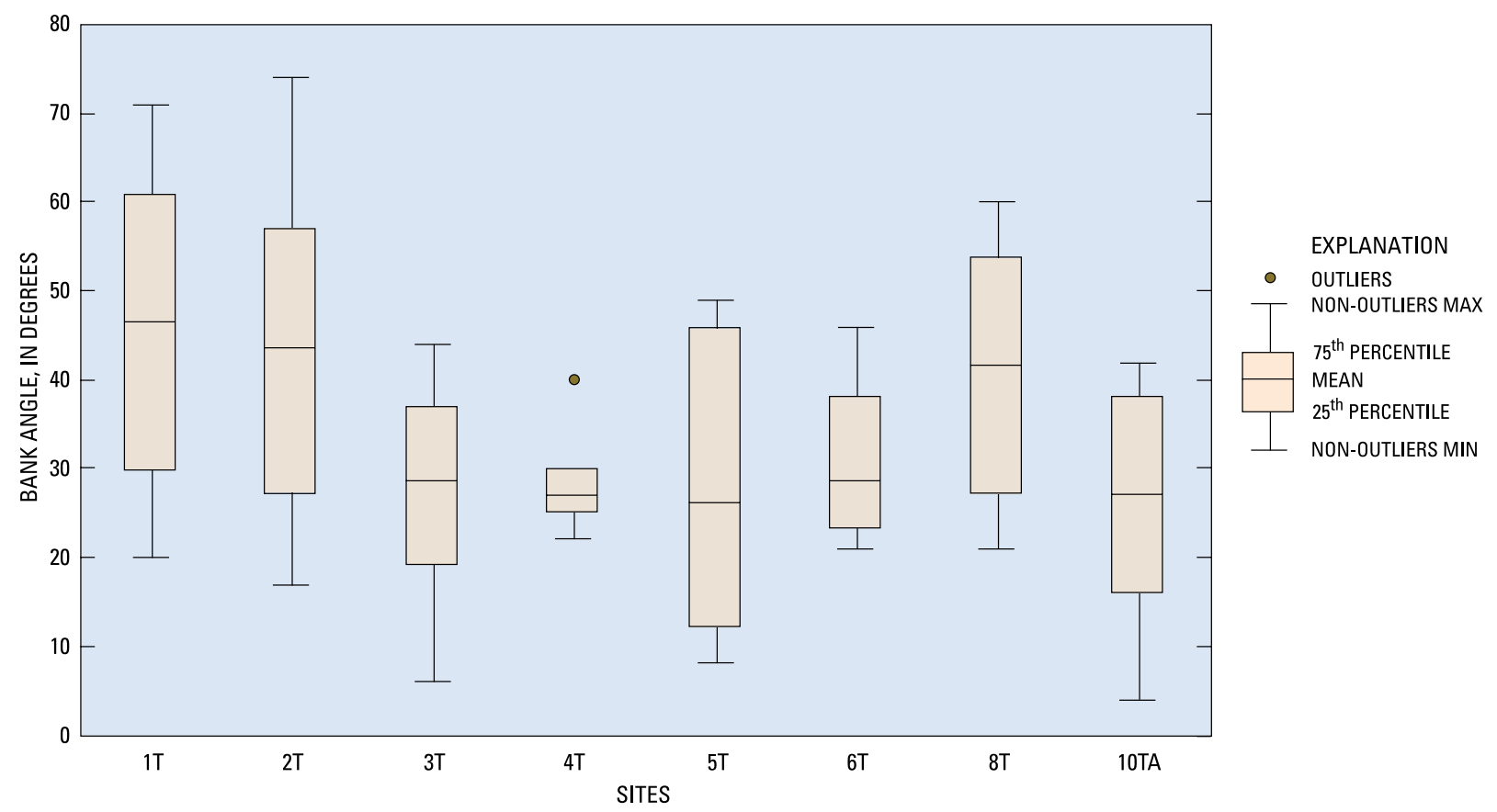

Figure 9. Box plots showing the mean and range of measured bank angles at sites in the Treyburn development study area.

Channel gradient ranged from 0.04 percent at site 5T to 1.63 percent at site $3 \mathrm{~T}$ (table 5). Mean cross sectional area ranged from 31.0 square feet $\left(\mathrm{ft}^{2}\right)$ at site $3 \mathrm{~T}$ to $1,226.7 \mathrm{ft}^{2}$ at site $5 \mathrm{~T}$. Survey data were used to generate profiles of cross sections (Appendix 1), planimetric maps of sites indicating tip of bank and water edge, and perspective maps of sites indicating elevation relief.
Indices such as channel width-to-depth ratios derived from cross-section data can provide valuable information on channel morphology as an indicator of channel shape. For example, a large channel width-todepth ratio may indicate a stream with a high potential for bed-load transport and bank erosion that generally would be characterized as unstable (Beschta and Platts, 1986).

Table 5. Summary of physical characteristics of streams in the Treyburn development study area, February 1997

[USGS, U.S. Geological Survey; $\mathrm{mi}^{2}$, square mile; $\mathrm{ft}$, feet; $\mathrm{ft}^{2}$, square foot; $\mathrm{SR}$, secondary road]

\begin{tabular}{|c|c|c|c|c|c|c|c|c|c|}
\hline $\begin{array}{l}\text { USGS station name and site number } \\
\text { (fig. 2) }\end{array}$ & $\begin{array}{c}\text { Drainage } \\
\text { area } \\
\left(\mathrm{mi}^{2}\right)\end{array}$ & $\begin{array}{l}\text { Channel } \\
\text { gradient } \\
\text { (percent) }\end{array}$ & $\begin{array}{c}\text { Mean } \\
\text { channel } \\
\text { bankfull } \\
\text { width } \\
\text { (ft) }\end{array}$ & $\begin{array}{c}\text { Mean } \\
\text { bankfull } \\
\text { depth } \\
\text { (ft) }\end{array}$ & $\begin{array}{c}\text { Mean } \\
\text { cross } \\
\text { sectional } \\
\text { area } \\
\left(\mathrm{ft}^{2}\right)\end{array}$ & $\begin{array}{c}\text { Mean } \\
\text { bank } \\
\text { angle } \\
\text { (degree) }\end{array}$ & $\begin{array}{c}\text { Mean } \\
\text { bank } \\
\text { height } \\
\text { (ft) }\end{array}$ & $\begin{array}{c}\text { Mean } \\
\text { bank } \\
\text { width } \\
\text { (ft) }\end{array}$ & $\begin{array}{c}\text { Channel } \\
\text { width to } \\
\text { depth }\end{array}$ \\
\hline Flat River tributary near Willardville, $1 \mathrm{~T}$ & 1.14 & 0.89 & 12.8 & 1.9 & 37.7 & 45.6 & 2.9 & 3.3 & 6.5 \\
\hline $\begin{array}{l}\text { Eno River tributary at SR } 1004 \text { near } \\
\text { Fairntosh, 2T }\end{array}$ & .57 & .76 & 15.1 & 2.4 & 54.9 & 43.7 & 3.4 & 5.0 & 6.3 \\
\hline Little River tributary near Durham, 3T & 1.02 & 1.63 & 18.9 & 1.3 & 31.0 & 27.2 & 1.6 & 3.6 & 14.5 \\
\hline $\begin{array}{l}\text { Little River at SR } 1461 \text { near Orange } \\
\text { Factory, 4T }\end{array}$ & 78.2 & 1.14 & 89.5 & 3.6 & 415.8 & 28.5 & 3.8 & 7.1 & 24.9 \\
\hline Flat River at Bahama, 5T & 149 & .04 & 198.8 & 7.4 & $1,226.7$ & 25.8 & 7.8 & 25.0 & 26.9 \\
\hline $\begin{array}{l}\text { Mountain Creek at SR } 1617 \text { near } \\
\text { Bahama, 6T }\end{array}$ & 8.00 & .61 & 27.7 & 2.3 & 81.3 & 30.8 & 2.8 & 4.9 & 12.0 \\
\hline Little River tributary at Fairntosh, 8T & .86 & .55 & 13.3 & 1.8 & 34.3 & 40.8 & 2.5 & 3.1 & 7.4 \\
\hline $\begin{array}{l}\text { Little River below Little River tributary } \\
\text { at Fairntosh, 10TA }\end{array}$ & 99.0 & .07 & 73.1 & 4.7 & 548.0 & 25.7 & 5.4 & 11.8 & 15.6 \\
\hline
\end{tabular}


Channels with cross sections indicating large width-todepth ratios can occur naturally but also can result from increased sediment loads, increased peak flows, mechanical damage to streambanks, or some combination of these factors. Because width usually increases faster than depth downstream, width-to-depth ratios tend to increase downstream, as indicated in this study. Thus, it is best if evaluations of width to depth as an index of channel shape are made among streams of comparable drainage area.

Evaluating cross-section data over time provides the opportunity to assess channel responses to natural events and human activities. An understanding of natural stream morphology is essential before evaluations of environmental effects on streams can be made. Natural periodic events, such as floods, can greatly alter sediment budgets and channel hydraulics. Hurricane Fran, which struck the area in September 1996, likely had such an effect during this study. In some cases, efforts are made to rehabilitate a stream or return the stream to an improved condition. Difficulties arise, however, in determining to what condition a stream should be improved. Evaluation of the relative effects of natural events and human activities and information needed to determine a baseline stream condition require temporal approaches to channel morphology analyses.

Channel cross-section data also provide valuable information regarding the potential to support aquatic biota, such as fish and benthic invertebrates. Fish and invertebrates are important components of State and Federal water-quality monitoring efforts to evaluate water-resource conditions of streams (Lenat, 1988; Fausch and others, 1990). However, using aquatic biota to evaluate water-resource conditions requires a basic understanding of physical stream conditions that support biological communities. Stream channel form influences hydrologic and hydraulic characteristics that define potentially usable habitat for aquatic biota. Channel cross sections provide quantitative data to assess the availability and quality of stream habitat (Hogan and Church, 1989; Heede and Rinne, 1990; Olson-Rutz and Marlow, 1992). Thus, the results of this study provide quantitative baseline data and repeatable procedures for additional future cross-section evaluation upon which to base management decisions regarding streams within the Treyburn development.

\section{WATER-OUALITY CONDITIONS}

Samples were collected between 1988 and 1998 at various frequencies and analyzed for concentrations of major ions, nutrients, trace metals, pesticides, and suspended sediment. This section presents a summary of the results of these analyses in order to characterize waterquality conditions at each site.

The ionic composition of water is determined by a number of factors, including soil type, land slope, amount of land disturbance, land use, and the chemistry of precipitation. These factors control the dissolution of chemical species. Chemical composition of the water is altered by point and nonpoint sources that contribute to streamflow. The composition of water at each site was characterized by analyses of major ions from samples collected in June 1991. Data were not available for Little River tributary at site 8T (fig. 2). For comparison, a sample collected in January 1992 on the Little River tributary (site 8TB) was used to represent conditions at this site. Most of the sites in the study area have a calcium and bicarbonate water type (fig. 10). Flat River (site 5T,

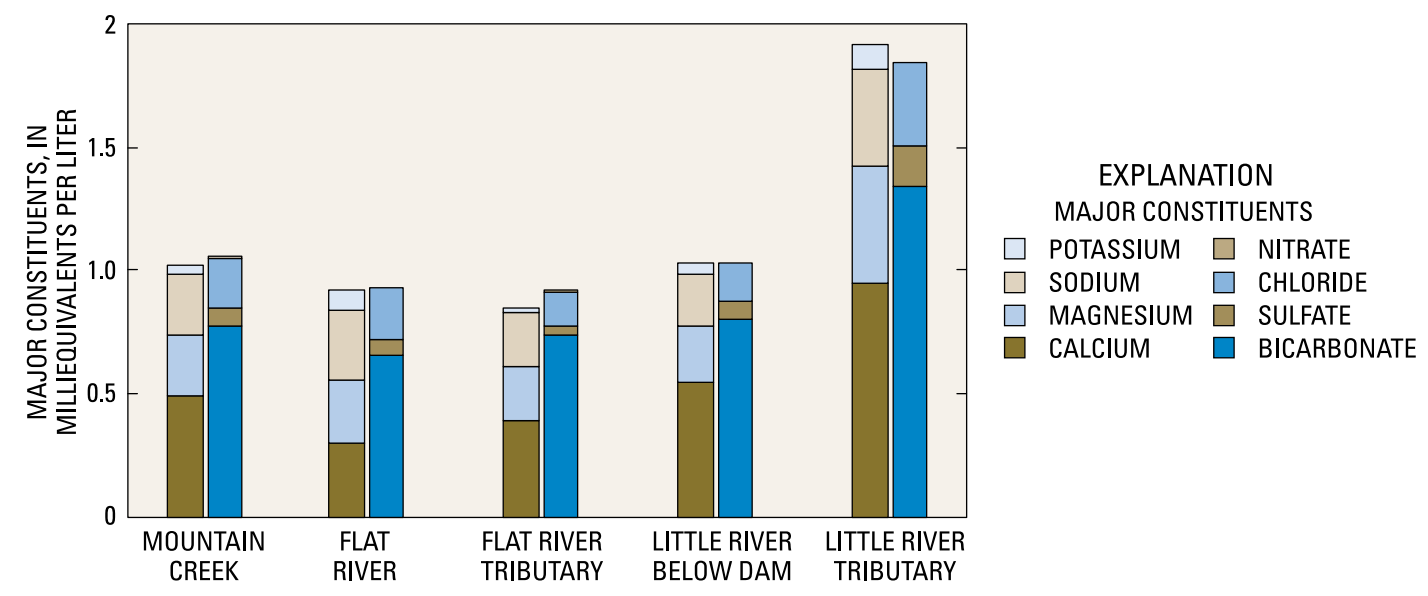

Figure 10. Major anion and cation concentrations in low-flow samples collected from Mountain Creek, Flat River, Flat River tributary, and Little River in June 1991, and from Little River tributary in January 1992. 
fig. 2) is a mixed cation and bicarbonate water type. Flat River and Flat River tributary (site 1T) drain soils derived from granite, so streamflow at these two sites would be expected to be somewhat less mineralized than streamflow at Mountain Creek (site 6T), Little River (site 10TA), and Little River tributary (site 8T), which drain soils derived from shale. Nevertheless, the substantially more mineralized water from Little River tributary (collected at site 8TB) when compared with other sites in the study (fig. 10) probably indicates the effects on water quality of land disturbance and nonpoint sources from the residential area and the golf course.

Flat River tributary (site 1T), which drains a relatively small and undisturbed forested watershed, was used as a baseline for comparison with concentrations of suspended sediment, metals and minor elements, and nutrients in the following discussion.

Specific conductance is a measure of the concentration of dissolved ions and is a surrogate for total dissolved solids concentration. Specific conductance generally is highest during low-flow periods when more highly mineralized ground water is the primary contributor to streamflow. Specific conductance decreases with increasing runoff from less mineralized precipitation (fig. 11A). Measurements of specific conductance ranged from 29 to 265 microsiemens per centimeter at 25 degrees Celsius ( $\mu \mathrm{S} / \mathrm{cm}$; table 6$)$. Highest specific conductance occurred in Little River tributary (median $147 \mu \mathrm{S} / \mathrm{cm}$ ), followed by Mountain Creek (median $100 \mu \mathrm{S} / \mathrm{cm}$ ). Measurements at the remaining sites were similar (median 72 to $76 \mu \mathrm{S} / \mathrm{cm}$ ). When related to unit discharge (in cubic feet per second per square mile), specific conductance can be compared among sites while accounting for the large range in drainage-basin sizes. The slopes of the specific conductance and unit discharge relation are statistically different for Little River tributary (site 8T; fig. 11A) compared to the other sites $(p<0.01)$. For Little River tributary, specific conductance is much greater than at the other sites during periods of low flow when ground-water contributions to streamflow are primary but is similar to the other sites during periods of high flow (greater than $8\left[\mathrm{ft}^{3} / \mathrm{s}\right] / \mathrm{mi}^{2}$ ). This difference in the quality of water at base flow, as previously discussed (fig. 10), may be due to the greater
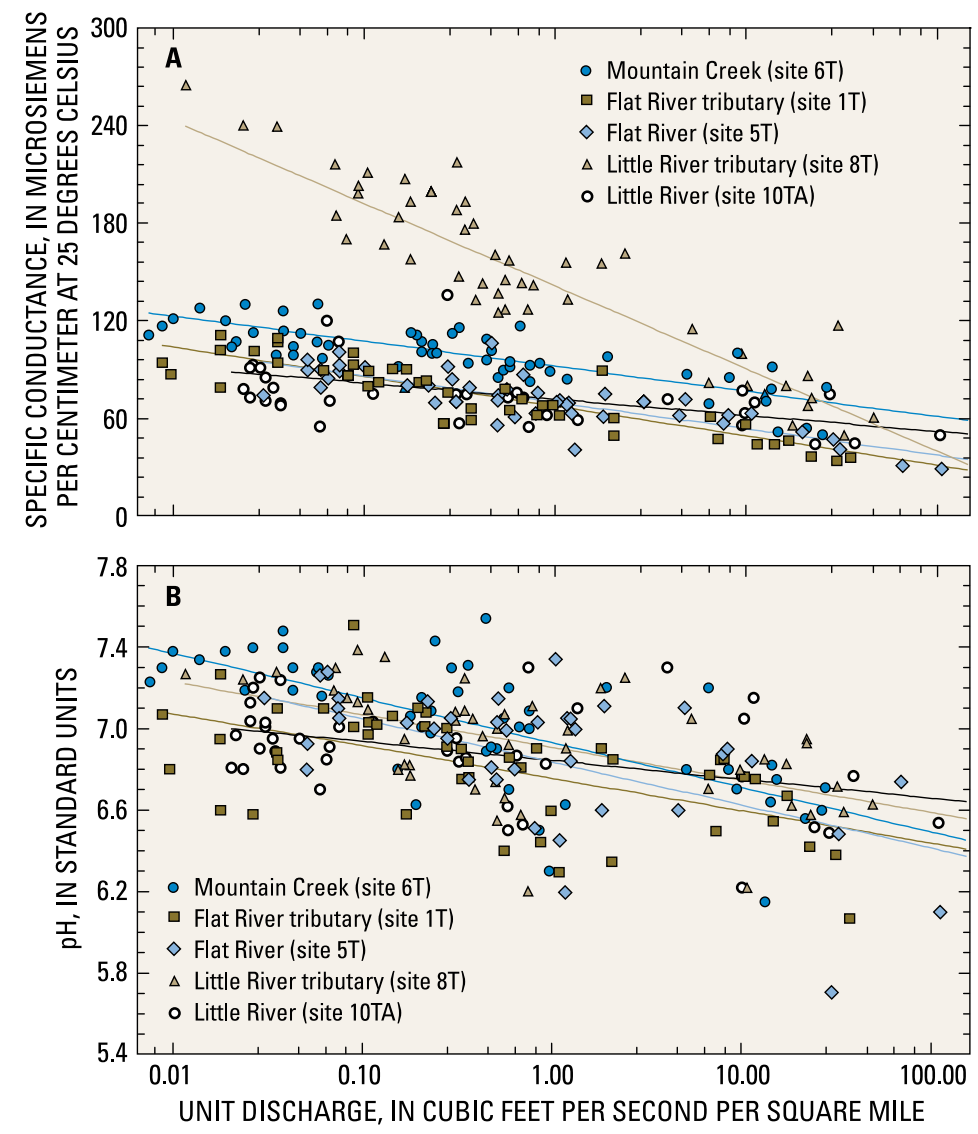

Figure 11. Relation between (A) specific conductance and unit discharge, and (B) pH and unit discharge for Mountain Creek, Flat River tributary, Flat River, Little River tributary, and Little River. 
Table 6. Summary statistics for physical measurements and suspended sediment collected at five sites in the Treyburn development study area, 1994-98

[ $\mu \mathrm{S} / \mathrm{cm}$, microsiemens per centimeter at 25 degrees Celsius; NA, not applicable; $\mathrm{mg} / \mathrm{L}$, milligram per liter; <, less than]

\begin{tabular}{|c|c|c|c|c|c|c|}
\hline Statistic & $\begin{array}{l}\text { North Carolina } \\
\text { ambient } \\
\text { water-quality } \\
\text { criteria }\end{array}$ & $\begin{array}{c}\text { Mountain } \\
\text { Creek } \\
\text { (site 6T) }\end{array}$ & $\begin{array}{c}\text { Little River } \\
\text { tributary } \\
\text { (site 8T) }\end{array}$ & $\begin{array}{l}\text { Little River } \\
\text { (site 10TA) }\end{array}$ & $\begin{array}{l}\text { Flat River } \\
\text { (site 5T) }\end{array}$ & $\begin{array}{c}\text { Flat River } \\
\text { tributary } \\
\text { (site 1T) }\end{array}$ \\
\hline Specific conductance $(\mu \mathrm{S} / \mathrm{cm})$ & NA & & & & & \\
\hline Minimum & & 50 & 50 & 44 & 34 & 29 \\
\hline $25^{\text {th }}$ percentile & & 89.5 & 115 & 63 & 60 & 62 \\
\hline Median & & 100 & 147 & 75 & 76 & 72 \\
\hline $75^{\text {th }}$ percentile & & 112 & 185 & 91 & 89 & 84 \\
\hline Maximum & & 130 & 265 & 136 & 111 & 106 \\
\hline Number of analyses & & 52 & 49 & 39 & 45 & 48 \\
\hline $\mathrm{pH}$ & \multicolumn{6}{|c|}{6 to 9 (except where lower pH occurs under natural conditions, such as in swamp waters) } \\
\hline Minimum & & 6.2 & 6.2 & 6.2 & 5.7 & 6.1 \\
\hline $25^{\text {th }}$ percentile & & 6.8 & 6.7 & 6.8 & 6.7 & 6.6 \\
\hline Median & & 7.1 & 7.0 & 6.9 & 6.9 & 6.8 \\
\hline $75^{\text {th }}$ percentile & & 7.3 & 7.1 & 7.0 & 7.1 & 7.0 \\
\hline Maximum & & 7.5 & 7.4 & 7.3 & 7.3 & 7.5 \\
\hline Number of analyses & & 52 & 49 & 39 & 44 & 48 \\
\hline Dissolved oxygen (mg/L) & 4.0 (minim & nstantaneol & & & & \\
\hline Minimum & & 6.9 & 5.2 & 5.2 & 3.7 & 2.2 \\
\hline $25^{\text {th }}$ percentile & & 7.9 & 6.8 & 6.3 & 7.2 & 7.4 \\
\hline Median & & 8.8 & 8.2 & 8.25 & 8.85 & 9 \\
\hline $75^{\text {th }}$ percentile & & 10.6 & 9.78 & 10.5 & 10.4 & 10.8 \\
\hline Maximum & & 13.74 & 13 & 12 & 13.5 & 13.24 \\
\hline Number of analyses & & 46 & 43 & 32 & 38 & 43 \\
\hline Suspended sediment (mg/L) & NA & & & & & \\
\hline Minimum & & $<1$ & 2 & 4 & 5 & $<1$ \\
\hline $25^{\text {th }}$ percentile & & 6 & 8 & 10 & 14 & 8 \\
\hline Median & & 12 & 21 & 13 & 21 & 20 \\
\hline $75^{\text {th }}$ percentile & & 40 & 47 & 24 & 85 & 42 \\
\hline Maximum & & 542 & 321 & 116 & 581 & 371 \\
\hline Number of analyses & & 51 & 49 & 39 & 39 & 47 \\
\hline
\end{tabular}

proportion of land disturbance in this basin or applications of fertilizers and other chemicals on the golf course and residential lawns.

Little variation occurred in $\mathrm{pH}$ among sites in the study. Overall, $\mathrm{pH}$ ranged from 5.7 to 7.5 (table 6). Median $\mathrm{pH}$ ranged from 6.8 to 7.1 among the study sites. The minimum $\mathrm{pH}$ was recorded at Flat River (site 5T) during high streamflow. At all sites, $\mathrm{pH}$ tended to decrease with increasing streamflow (fig. 11B).

Dissolved oxygen concentrations ranged from 2.2 to $13.74 \mathrm{mg} / \mathrm{L}$ (table 6 ). Median concentrations ranged from 8.2 to $9.0 \mathrm{mg} / \mathrm{L}$. The North Carolina criterion for dissolved oxygen for protection of aquatic life is
$4.0 \mathrm{mg} / \mathrm{L}$. Two measurements failed to meet this criterion-one was at Flat River $(3.7 \mathrm{mg} / \mathrm{L})$ on October 25, 1994, and the other was at Flat River tributary $(2.2 \mathrm{mg} / \mathrm{L})$ on September 22, 1998. The second occurrence was during an extended low-flow period when streamflow was only $0.01 \mathrm{ft}^{3} / \mathrm{s}$.

\section{Suspended Sediment}

Excessive sedimentation has been identified as one of the major factors leading to habitat degradation. Habitat degradation is the most prevalent surface-waterquality problem in North Carolina (North Carolina 
Division of Water Quality, 2000). Sediment is transported to streams when soil particles are eroded from (1) the land surface and carried in overland runoff, (2) streambanks, and (3) the resuspension of deposits on the streambed. Increased sediment delivery to streams is one of the primary adverse effects of land-disturbing activities, such as agriculture and urban development.

Sampled suspended-sediment concentrations ranged from less than $1 \mathrm{mg} / \mathrm{L}$ to $581 \mathrm{mg} / \mathrm{L}$ and were not significantly different (analysis of variance; $p=0.12$ ) among sites (table 6; fig. 12A). Median concentrations ranged from 12 to $21 \mathrm{mg} / \mathrm{L}$. The smallest range in concentration occurred in Little River downstream from the Little River Reservoir. Typically, suspended-sediment concentration increases with increasing streamflow (fig. 12B). For Little River, the slope of the least-squares regression line was not significantly greater than zero $(p<0.05)$. The reservoir allows particulate material to
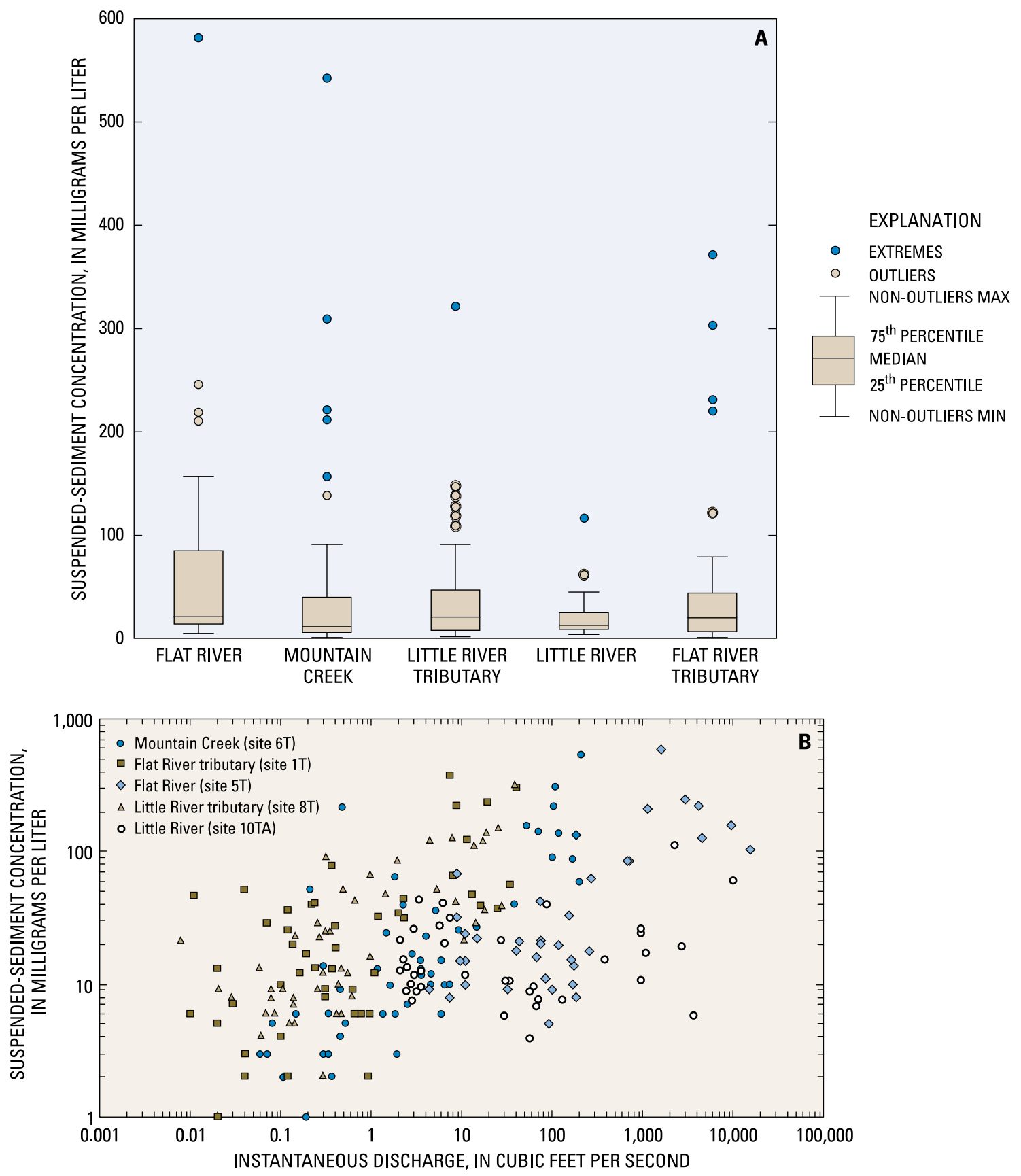

Figure 12. (A) Distribution of suspended sediment, by site, and (B) relation of suspended-sediment concentrations to discharge at sites in the Treyburn development study area. 
settle, thus trapping suspended sediment in the reservoir. Childress and Treece (1996) estimated trapping efficiency for suspended sediment to be 87 percent in Lake Michie and about 85 percent in Little River Reservoir.

\section{Metals and Minor Elements}

Selected stream samples were analyzed for total concentrations of aluminum, iron, manganese, arsenic, cadmium, chromium, cobalt, copper, lead, mercury, molybdenum, nickel, selenium, silver, and zinc. Only one sample was collected from the Little River (site 10TA) and only three samples were collected from the Flat River (site 5T) for analysis of these elements (table 7). Arsenic, lead, mercury, cadmium, and chromium are among the top 20 hazardous substances listed by the U.S.

Environmental Protection Agency (USEPA) in 1999 (U.S. Department of Health and Human Services, 1999). Water-quality criteria for the protection of aquatic life have been established by the North Carolina Department of Environment and Natural Resources (1997a) for arsenic, cadmium, copper, iron, lead, manganese, nickel, silver, zinc, selenium, and mercury.

Few metals and trace elements, except aluminum, iron, and manganese, were detected in concentrations that exceeded the laboratory reporting levels or the waterquality criteria (table 7). Garrett and Bales (1995) reported a similar finding for the period 1988-93. The reporting level was not exceeded for cadmium, selenium, or mercury at any site. Arsenic was detected once at Little River (site 10TA) and Mountain Creek (site 6T), and twice at Little River tributary (site 8T). Arsenic is a component of some agricultural pesticides.

The reporting level for silver $(1 \mu \mathrm{g} / \mathrm{L})$ is greater than the action level $(0.06 \mu \mathrm{g} / \mathrm{L})$, and both the action level and the reporting level were exceeded at Little River tributary. The reporting level for molybdenum was exceeded once in the Little River tributary, and the reporting level for cobalt was exceeded in the Little River tributary, Flat River tributary, and Mountain Creek.

Table 7. Summary statistics for metals and minor elements collected at five sites in the Treyburn development study area, 1994-98

$[\mu \mathrm{g} / \mathrm{L}$, microgram per liter; NA, not applicable; —, insufficient sample size to determine the statistic; MCL, maximum contaminant level; USEPA, U.S. Environmental Protection Agency; <, less than]

\begin{tabular}{|c|c|c|c|c|c|c|}
\hline Statistic & $\begin{array}{l}\text { North Carolina } \\
\text { ambient } \\
\text { water-quality } \\
\text { criteria }\end{array}$ & $\begin{array}{l}\text { Mountain } \\
\text { Creek } \\
\text { (site 6T) }\end{array}$ & $\begin{array}{c}\text { Little River } \\
\text { tributary } \\
\text { (site 8T) }\end{array}$ & $\begin{array}{l}\text { Little River } \\
\text { (site 10TA) }\end{array}$ & $\begin{array}{c}\text { Flat River } \\
\text { (site } 5 T \text { ) }\end{array}$ & $\begin{array}{c}\text { Flat River } \\
\text { tributary } \\
\text { (site 1T) }\end{array}$ \\
\hline Aluminum ( $\mu \mathrm{g} / \mathrm{L})$ & \multicolumn{3}{|c|}{ NA (Reporting level is $28 \mu \mathrm{g} / \mathrm{L}$ ) } & & & \\
\hline Minimum & & 77 & 90 & 430 & 300 & 37 \\
\hline $25^{\text {th }}$ percentile & & 446 & 130 & - & - & - \\
\hline Median & & 690 & 820 & - & 530 & 240 \\
\hline $75^{\text {th }}$ percentile & & 1,300 & 901 & - & - & 1,500 \\
\hline Maximum & & 3,230 & 5,100 & 430 & 1,100 & 7,600 \\
\hline Number of analyses & & 17 & 17 & 1 & 3 & 17 \\
\hline Arsenic $(\mu \mathrm{g} / \mathrm{L})$ & 50 & & & & & \\
\hline Minimum & & $<1$ & $<1$ & 2 & $<1$ & $<1$ \\
\hline $25^{\text {th }}$ percentile & & $<1$ & $<1$ & - & - & $<1$ \\
\hline Median & & $<1$ & $<1$ & - & $<1$ & $<1$ \\
\hline $75^{\text {th }}$ percentile & & $<1$ & $<1$ & - & - & $<1$ \\
\hline Maximum & & 2 & 5 & 2 & $<1$ & $<1$ \\
\hline Number of analyses & & 17 & 17 & 1 & 3 & 17 \\
\hline Cadmium $(\mu \mathrm{g} / \mathrm{L})$ & 2 & & & & & \\
\hline Minimum & & $<1$ & $<1$ & $<1$ & $<1$ & $<1$ \\
\hline $25^{\text {th }}$ percentile & & $<1$ & $<1$ & - & - & $<1$ \\
\hline Median & & $<1$ & $<1$ & - & $<1$ & $<1$ \\
\hline $75^{\text {th }}$ percentile & & $<1$ & $<1$ & - & - & $<1$ \\
\hline Maximum & & $<1$ & $<1$ & $<1$ & $<1$ & $<1$ \\
\hline Number of analyses & & 17 & 17 & 1 & 3 & 17 \\
\hline
\end{tabular}


Table 7. Summary statistics for metals and minor elements collected at five sites in the Treyburn development study area, 1994-98-Continued

$[\mu \mathrm{g} / \mathrm{L}$, microgram per liter; NA, not applicable; —, insufficient sample size to determine the statistic; MCL, maximum contaminant level; USEPA,

U.S. Environmental Protection Agency; <, less than]

\begin{tabular}{|c|c|c|c|c|c|c|}
\hline Statistic & $\begin{array}{c}\text { North Carolina } \\
\text { ambient } \\
\text { water-quality } \\
\text { criteria }\end{array}$ & $\begin{array}{l}\text { Mountain } \\
\text { Creek } \\
\text { (site 6T) }\end{array}$ & $\begin{array}{c}\text { Little River } \\
\text { tributary } \\
\text { (site 8T) }\end{array}$ & $\begin{array}{l}\text { Little River } \\
\text { (site 10TA) }\end{array}$ & $\begin{array}{c}\text { Flat River } \\
\text { (site 5T) }\end{array}$ & $\begin{array}{c}\text { Flat River } \\
\text { tributary } \\
\text { (site 1T) }\end{array}$ \\
\hline Chromium $(\mu \mathrm{g} / \mathrm{L})$ & 50 & & & & & \\
\hline Minimum & & $<1$ & $<1$ & $<1$ & $<1$ & $<1$ \\
\hline $25^{\text {th }}$ percentile & & $<1$ & $<1$ & - & - & $<1$ \\
\hline Median & & $<1$ & $<1$ & - & 1.6 & $<1$ \\
\hline $75^{\text {th }}$ percentile & & $<1$ & $<1$ & - & - & $<1.4$ \\
\hline Maximum & & 18 & 3.9 & $<1$ & 1.9 & 2.9 \\
\hline Number of analyses & & 17 & 17 & 1 & 3 & 17 \\
\hline Cobalt $(\mu \mathrm{g} / \mathrm{L})$ & NA & & & & & \\
\hline Minimum & & $<1$ & $<1$ & $<1$ & $<1$ & $<1$ \\
\hline $25^{\text {th }}$ percentile & & $<1$ & $<1$ & - & - & $<1$ \\
\hline Median & & $<1$ & $<1$ & - & $<1$ & $<1$ \\
\hline $75^{\text {th }}$ percentile & & 2 & $<1$ & - & - & $<1$ \\
\hline Maximum & & 6.2 & 3 & $<1$ & $<1$ & 5 \\
\hline Number of analyses & & 17 & 17 & 1 & 3 & 17 \\
\hline Copper ( $\mu \mathrm{g} / \mathrm{L})$ & $7^{a}$ & & & & & \\
\hline Minimum & & $<1$ & $<1$ & 4 & 2 & $<1$ \\
\hline $25^{\text {th }}$ percentile & & $<1$ & 2.3 & - & - & $<1$ \\
\hline Median & & $<1$ & 4 & - & 2 & $<1$ \\
\hline $75^{\text {th }}$ percentile & & 2.6 & 4 & - & - & 3 \\
\hline Maximum & & 4 & 8 & 4 & 3 & 4 \\
\hline Number of analyses & & 17 & 17 & 1 & 3 & 17 \\
\hline Iron $(\mu \mathrm{g} / \mathrm{L})$ & $1,000^{\mathrm{a}}$ & & & & & \\
\hline Minimum & & 439 & 558 & 650 & 480 & 230 \\
\hline $25^{\text {th }}$ percentile & & 770 & 790 & - & - & 510 \\
\hline Median & & 1,400 & 1,165 & - & 1,300 & 670 \\
\hline $75^{\text {th }}$ percentile & & 2,600 & 1,900 & - & - & 1,700 \\
\hline Maximum & & 7,950 & 4,700 & 650 & 1,500 & 6,100 \\
\hline Number of analyses & & 17 & 17 & 1 & 3 & 17 \\
\hline Lead $(\mu \mathrm{g} / \mathrm{L})$ & 25 & & & & & \\
\hline Minimum & & $<1$ & $<1$ & $<1$ & $<1$ & $<1$ \\
\hline $25^{\text {th }}$ percentile & & $<1$ & $<1$ & - & - & $<1$ \\
\hline Median & & 2 & $<1$ & - & 2 & $<1$ \\
\hline $75^{\text {th }}$ percentile & & 4 & 2 & - & - & 2 \\
\hline Maximum & & 12.9 & 5 & $<1$ & 2 & 5 \\
\hline Number of analyses & & 17 & 17 & 1 & 3 & 17 \\
\hline Manganese $(\mu \mathrm{g} / \mathrm{L})$ & $200^{b}$ & & & & & \\
\hline Minimum & & 31 & 60 & 170 & 20 & 10 \\
\hline $25^{\text {th }}$ percentile & & 80 & 140 & - & - & 30 \\
\hline Median & & 220 & 180 & - & 150 & 60 \\
\hline $75^{\text {th }}$ percentile & & 450 & 260 & - & - & 110 \\
\hline Maximum & & 2,290 & 566 & 170 & 160 & 540 \\
\hline Number of analyses & & 17 & 17 & 1 & 3 & 17 \\
\hline
\end{tabular}


Table 7. Summary statistics for metals and minor elements collected at five sites in the Treyburn development study area, 1994-98-Continued

$[\mu \mathrm{g} / \mathrm{L}$, microgram per liter; NA, not applicable; —, insufficient sample size to determine the statistic; MCL, maximum contaminant level; USEPA,

U.S. Environmental Protection Agency; <, less than]

\begin{tabular}{|c|c|c|c|c|c|c|}
\hline Statistic & $\begin{array}{l}\text { North Carolina } \\
\text { ambient } \\
\text { water-quality } \\
\text { criteria }\end{array}$ & $\begin{array}{l}\text { Mountain } \\
\text { Creek } \\
\text { (site 6T) }\end{array}$ & $\begin{array}{c}\text { Little River } \\
\text { tributary } \\
\text { (site 8T) }\end{array}$ & $\begin{array}{l}\text { Little River } \\
\text { (site 10TA) }\end{array}$ & $\begin{array}{c}\text { Flat River } \\
\text { (site 5T) }\end{array}$ & $\begin{array}{c}\text { Flat River } \\
\text { tributary } \\
\text { (site 1T) }\end{array}$ \\
\hline Mercury $(\mu \mathrm{g} / \mathrm{L})$ & 0.012 & & & & & \\
\hline Minimum & & $<0.1$ & $<0.1$ & $<0.1$ & $<0.1$ & $<0.1$ \\
\hline $25^{\text {th }}$ percentile & & $<.1$ & $<.1$ & - & - & $<.1$ \\
\hline Median & & $<.1$ & $<.1$ & - & $<.1$ & $<.1$ \\
\hline $75^{\text {th }}$ percentile & & $<.1$ & $<.1$ & - & - & $<.1$ \\
\hline Maximum & & $<.1$ & $<.1$ & $<.1$ & $<.1$ & $<.1$ \\
\hline Number of analyses & & 17 & 17 & 1 & 3 & 17 \\
\hline Molybdenum $(\mu \mathrm{g} / \mathrm{L})$ & NA & & & & & \\
\hline Minimum & & $<1$ & $<1$ & $<1$ & $<1$ & $<1$ \\
\hline $25^{\text {th }}$ percentile & & $<1$ & $<1$ & - & - & $<1$ \\
\hline Median & & $<1$ & $<1$ & - & $<1$ & $<1$ \\
\hline $75^{\text {th }}$ percentile & & $<1$ & $<1$ & - & - & $<1$ \\
\hline Maximum & & $<1$ & 1.4 & $<1$ & $<1$ & $<1$ \\
\hline Number of analyses & & 17 & 17 & 1 & 3 & 17 \\
\hline Nickel $(\mu \mathrm{g} / \mathrm{L})$ & $88\left(25^{b}\right)$ & & & & & \\
\hline Minimum & & $<1$ & $<1$ & $<1$ & $<1$ & $<1$ \\
\hline $25^{\text {th }}$ percentile & & $<1$ & $<1$ & - & - & $<1$ \\
\hline Median & & $<1$ & $<1$ & - & $<1$ & $<1$ \\
\hline $75^{\text {th }}$ percentile & & $<1$ & $<1$ & - & - & $<1$ \\
\hline Maximum & & 2 & 3 & $<1$ & 24 & 3 \\
\hline Number of analyses & & 17 & 17 & 1 & 3 & 17 \\
\hline Selenium ( $\mu \mathrm{g} / \mathrm{L})$ & 5 & & & & & \\
\hline Minimum & & $<1$ & $<1$ & $<1$ & $<1$ & $<1$ \\
\hline $25^{\text {th }}$ percentile & & $<1$ & $<1$ & - & - & $<1$ \\
\hline Median & & $<1$ & $<1$ & - & $<1$ & $<1$ \\
\hline $75^{\text {th }}$ percentile & & $<1$ & $<1$ & - & - & $<1$ \\
\hline Maximum & & $<1$ & $<1$ & $<1$ & $<1$ & $<1$ \\
\hline Number of analyses & & 17 & 17 & 1 & 3 & 17 \\
\hline Silver $(\mu \mathbf{g} / \mathrm{L})$ & $0.06^{\mathrm{a}}$ & & & & & \\
\hline Minimum & & $<1$ & $<1$ & $<1$ & $<1$ & $<1$ \\
\hline $25^{\text {th }}$ percentile & & $<1$ & $<1$ & - & - & $<1$ \\
\hline Median & & $<1$ & $<1$ & - & $<1$ & $<1$ \\
\hline $75^{\text {th }}$ percentile & & $<1$ & $<1$ & - & - & $<1$ \\
\hline Maximum & & $<1$ & 2 & $<1$ & $<1$ & $<1$ \\
\hline Number of analyses & & 17 & 17 & 1 & 3 & 17 \\
\hline Zinc $(\mu \mathrm{g} / \mathrm{L})$ & $50^{\mathrm{a}}$ & & & & & \\
\hline Minimum & & $<10$ & $<10$ & $<10$ & $<10$ & $<10$ \\
\hline $25^{\text {th }}$ percentile & & $<10$ & $<10$ & - & - & $<10$ \\
\hline Median & & $<10$ & $<10$ & - & $<10$ & $<10$ \\
\hline $75^{\text {th }}$ percentile & & $<10$ & $<10$ & - & - & $<10$ \\
\hline Maximum & & 25 & 20 & $<10$ & $<10$ & 21 \\
\hline Number of analyses & & 17 & 17 & 1 & 3 & 17 \\
\hline
\end{tabular}

${ }^{a}$ Action level, considered as a numeric ambient water-quality standard for purposes other than wastewater-discharge permitting.

${ }^{\mathrm{b}}$ Criterion for waters classified as WS-I to WS-IV. 
Currently (2001), there are no water-quality criteria for cobalt or molybdenum. The reporting level for mercury $(0.1 \mu \mathrm{g} / \mathrm{L})$ exceeds the criterion $(0.012 \mu \mathrm{g} / \mathrm{L})$.

Lead, nickel, and chromium were detected at all but Little River (site 10TA), but detections were less than half the criterion (table 7). Sediment trapping in Little River Reservoir may reduce the concentrations of metals that adsorb to sediment particles. Copper was detected at least once at each site and exceeded the action level at Little River tributary (site $8 \mathrm{~T} ; 8 \mu \mathrm{g} / \mathrm{L}$ ). Copper is a component of some fungicides, and may reflect use of these chemicals on residential or golf-course properties. Zinc was detected at Little River tributary (site 8T), Flat River tributary (site 1T), and Mountain Creek (site 6T), but detections were no more than half the action level. The number and magnitude of detections of chromium, copper, lead, nickel, and zinc were far smaller than those reported for Charlotte urban and mixed land-use watersheds (Bales and others, 1999).

Aluminum, iron, and manganese are found in abundance in the ambient environment. Concentrations generally were greater in Mountain Creek and Little River tributary than in Flat River tributary. The median iron concentration at Mountain Creek $(1,400 \mu \mathrm{g} / \mathrm{L})$ and Little River tributary $(1,165 \mu \mathrm{g} / \mathrm{L})$ exceeded the action level for iron of $1,000 \mu \mathrm{g} / \mathrm{L}$. The criterion for manganese $(200 \mu \mathrm{g} / \mathrm{L})$ applicable to waters classified as water supply (WS-I to WS-IV) was exceeded in half the samples from Mountain Creek. The distributions of sampled concentrations of aluminum, iron, and manganese also were similar to those reported by Garrett and Bales (1995) for 1988-93.

\section{Nutrients}

Concentrations of nitrite plus nitrate, ammonia, and organic nitrogen as $\mathrm{N}$ and orthophosphate and total phosphorus as $\mathrm{P}$ were analyzed in stream samples collected monthly at the five study sites (fig. 2). The smallest range and median concentrations of total organic nitrogen, nitrite plus nitrate, ammonia, and total phosphorus occurred in the relatively undisturbed, forested Flat River tributary (site 1T, table 8; fig. 13). The range and median concentrations of orthophosphate were similar among all sites except Little River tributary. The statistical significance $(p<0.05)$ of differences in concentrations among sites was tested by using Tukey's multiple comparison test (fig. 13; Helsel and Hirsch, 1992).

Total organic nitrogen concentrations ranged from less than $0.10 \mathrm{mg} / \mathrm{L}$ to $1.97 \mathrm{mg} / \mathrm{L}$ (table 8 ). The maximum concentration occurred in Mountain Creek, and the maximum median concentration occurred in Little River $(0.46 \mathrm{mg} / \mathrm{L})$. Concentrations in Flat River tributary, the forested site, were significantly $(p<0)$ less than at Mountain Creek, Little River, and Little River tributary (fig. 13). Ammonia concentrations ranged from less than 0.01 to $0.36 \mathrm{mg} / \mathrm{L}$ (table 8 ). Median concentrations were near the reporting level. There were no significant differences among sites. Ammonia concentrations in excess of $0.1 \mathrm{mg} / \mathrm{L}$ may be considered evidence of some anthropogenic effect, and concentrations in excess of $0.2 \mathrm{mg} / \mathrm{L}$ may indicate urban effects (Mueller and others, 1995). Only Mountain Creek and Little River tributary had ammonia concentrations in excess of $0.2 \mathrm{mg} / \mathrm{L}$ in a few samples.

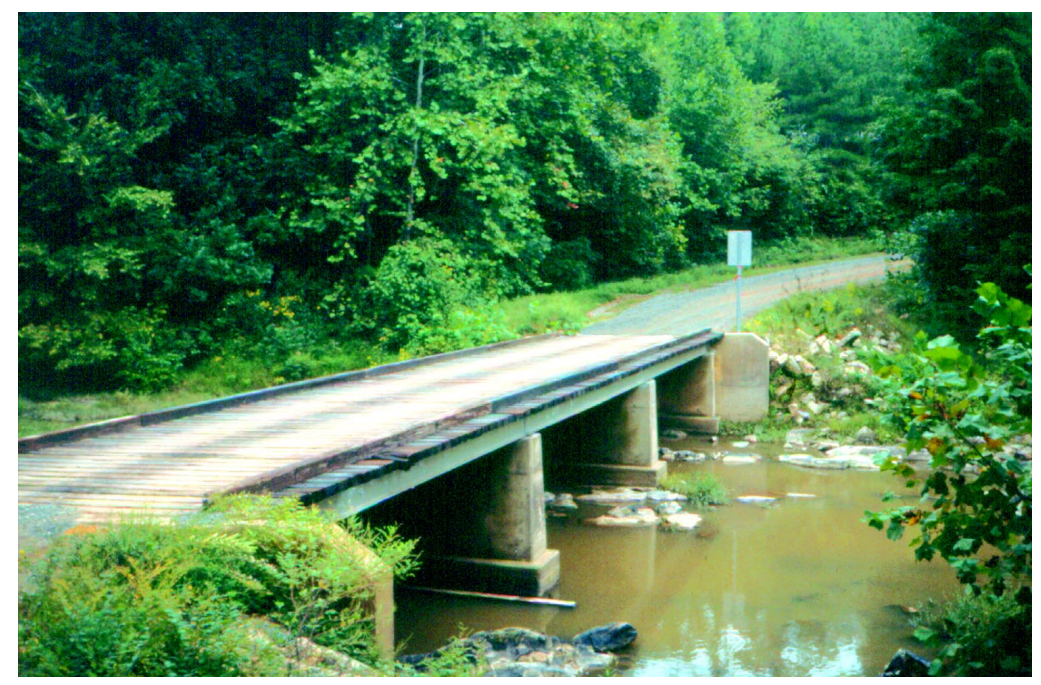

Flat River at Bahama (site 5T, USGS gaging station 02085500). 
Table 8. Summary statistics for nutrients detected in stream samples collected at five sites in the Treyburn development study area, 1994-98

[mg/L, milligram per liter; <, less than]

\begin{tabular}{|c|c|c|c|c|c|}
\hline Statistic & $\begin{array}{l}\text { Mountain Creek } \\
\text { (site 6T) }\end{array}$ & $\begin{array}{c}\text { Little River } \\
\text { tributary } \\
\text { (site 8T) }\end{array}$ & $\begin{array}{l}\text { Little River } \\
\text { (site 10TA) }\end{array}$ & $\begin{array}{c}\text { Flat River } \\
\text { (site 5T) }\end{array}$ & $\begin{array}{c}\text { Flat River } \\
\text { tributary } \\
\text { (site 1T) }\end{array}$ \\
\hline \multicolumn{6}{|c|}{ Total organic nitrogen (mg/L) } \\
\hline Minimum & $<0.20$ & $<0.20$ & $<0.28$ & $<0.20$ & $<0.10$ \\
\hline $25^{\text {th }}$ percentile & .27 & $<.20$ & .37 & .30 & $<.20$ \\
\hline Median & .30 & .40 & .46 & .34 & .20 \\
\hline $75^{\text {th }}$ percentile & .60 & .70 & .60 & .52 & .35 \\
\hline Maximum & 1.97 & 1.70 & .90 & 1.24 & .80 \\
\hline Number of samples & 51 & 48 & 37 & 39 & 46 \\
\hline \multicolumn{6}{|c|}{ Nitrite plus nitrate (mg/L) } \\
\hline Minimum & $<.05$ & $<.05$ & $<.05$ & $<.05$ & $<.05$ \\
\hline $25^{\text {th }}$ percentile & .17 & .06 & .10 & .15 & .05 \\
\hline Median & .30 & .10 & .20 & .27 & .08 \\
\hline $75^{\text {th }}$ percentile & .39 & .25 & .28 & .33 & .12 \\
\hline Maximum & .55 & .79 & .45 & .80 & .34 \\
\hline Number of samples & 51 & 48 & 37 & 39 & 46 \\
\hline \multicolumn{6}{|l|}{ Ammonia (mg/L) } \\
\hline Minimum & $<.02$ & $<.02$ & $<.02$ & $<.01$ & $<.02$ \\
\hline $25^{\text {th }}$ percentile & $<.02$ & $<.02$ & .02 & $<.02$ & $<.02$ \\
\hline Median & .02 & .02 & .04 & .02 & $<.02$ \\
\hline $75^{\text {th }}$ percentile & .05 & .05 & .08 & .06 & .02 \\
\hline Maximum & .32 & .36 & .14 & .14 & .12 \\
\hline Number of samples & 51 & 48 & 37 & 39 & 46 \\
\hline \multicolumn{6}{|c|}{ Total phosphorus (mg/L) } \\
\hline Minimum & $<.01$ & $<.01$ & $<.01$ & $<.01$ & $<.01$ \\
\hline $25^{\text {th }}$ percentile & .02 & $<.01$ & .02 & .02 & $<.01$ \\
\hline Median & .03 & .04 & .04 & .04 & .02 \\
\hline $75^{\text {th }}$ percentile & .07 & .12 & .07 & .11 & .04 \\
\hline Maximum & .50 & .87 & .27 & .21 & .15 \\
\hline Number of samples & 51 & 48 & 37 & 39 & 46 \\
\hline \multicolumn{6}{|l|}{ Orthophosphate (mg/L) } \\
\hline Minimum & $<.01$ & $<.01$ & $<.01$ & $<.01$ & $<.01$ \\
\hline $25^{\text {th }}$ percentile & $<.01$ & $<.01$ & $<.01$ & $<.01$ & $<.01$ \\
\hline Median & .02 & .02 & .01 & .02 & $<.01$ \\
\hline $75^{\text {th }}$ percentile & .03 & .07 & .02 & .02 & .01 \\
\hline Maximum & .12 & .76 & .22 & .05 & .12 \\
\hline Number of samples & 51 & 48 & 37 & 39 & 46 \\
\hline
\end{tabular}

Nitrite-plus-nitrate concentrations ranged from less than 0.05 to $0.80 \mathrm{mg} / \mathrm{L}$. The maximum concentrations occurred in Flat River and Little River tributary $(0.80$ and $0.79 \mathrm{mg} / \mathrm{L}$, respectively, table 8$)$. The greatest median nitrite-plus-nitrate concentration occurred in Mountain Creek. Nitrite-plus-nitrate concentrations were lowest in the forested Flat River tributary and significantly lower than in Mountain Creek and Flat River, which have mixed land covers. Nitrite-plusnitrate concentrations were more affected by increased discharge in Little River tributary than at the other sites. The increased concentration with increased discharge at Little River tributary is indicative of a nonpoint nitrogen source. 

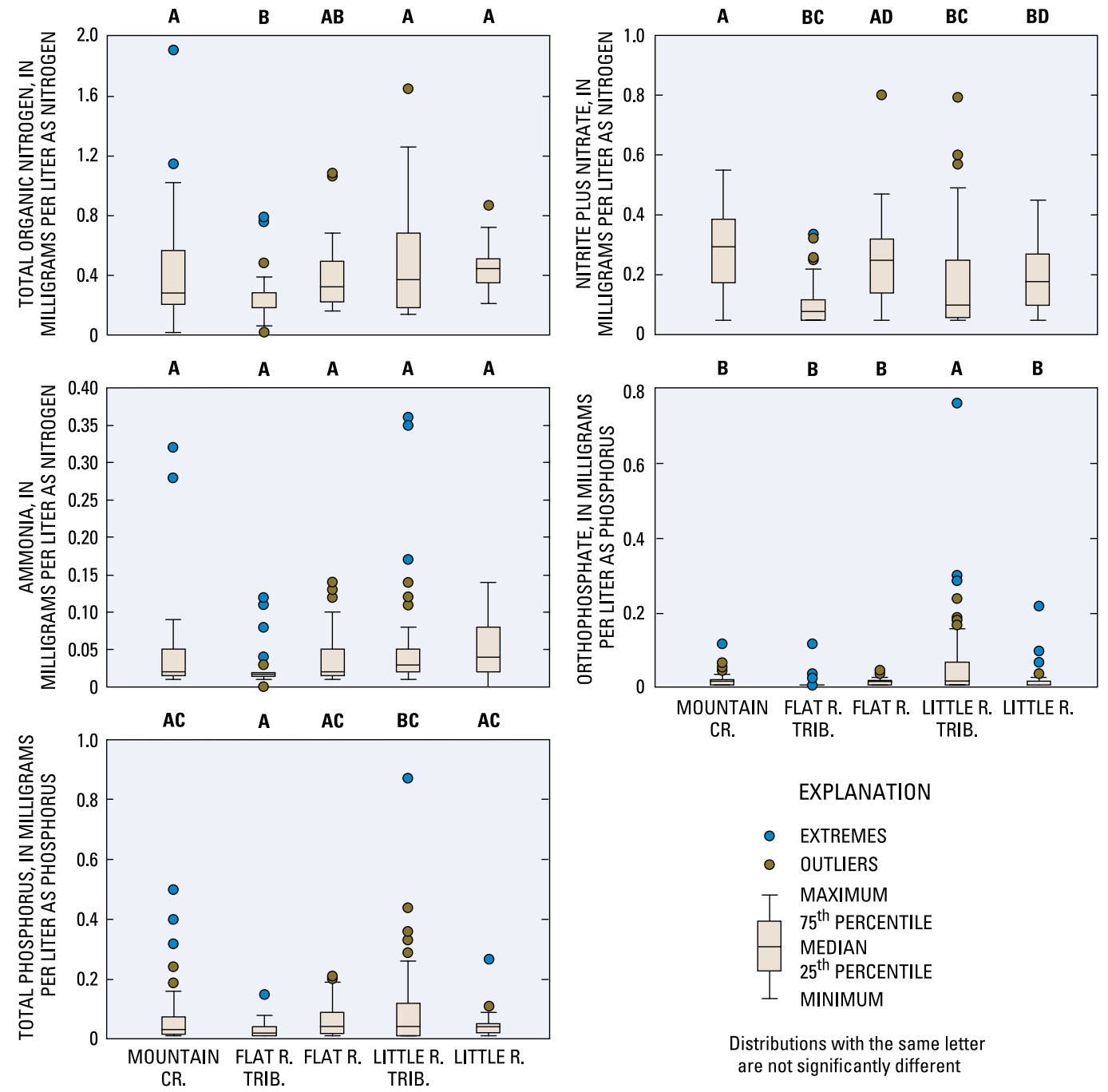

Distributions with the same letter are not significantly different

Figure 13. Box plots showing the distribution of nutrients, by site, in the Treyburn development study area, and the results of significance testing.

Total phosphorus concentrations ranged from less than 0.01 to $0.87 \mathrm{mg} / \mathrm{L}$ (table 8). The maximum concentration occurred at Little River tributary. Median concentrations were similar at each site, and only concentrations at Little River tributary were significantly greater than those at Flat River tributary ( $p<0.05$; fig. 13). At Flat River tributary, Mountain Creek, and Little River, less than 16 percent of analyses exceeded the USEPArecommended limit of $0.1 \mathrm{mg} / \mathrm{L}$ for phosphorus concentration in streams. At Little River tributary and Flat River, nearly 30 percent of phosphorus concentrations exceeded this limit. However, phosphorus concentrations at all of the Treyburn sites were low compared to sites nationally. In a summary of USGS data collected for the NAWQA Program, Mueller and others (1995) reported that concentrations typically exceeded $0.1 \mathrm{mg} / \mathrm{L}$.
Likewise, samples collected at sites in the coastal region of North Carolina, as part of the NAWQA AlbemarlePamlico study, typically had phosphorus concentrations in excess of $0.1 \mathrm{mg} / \mathrm{L}$ (Harned and others, 1995). Bales and others (1999) reported that urban, residential, and developing sites in Charlotte had median phosphorus concentrations at least double this limit.

Because orthophosphates are only moderately soluble and are readily bioavailable, concentrations usually are small-less than a few tenths of a milligram per liter. Orthophosphate concentrations ranged from less than 0.01 to $0.76 \mathrm{mg} / \mathrm{L}$ as phosphorus. The maximum orthophosphate concentrations occurred in Little River tributary, where concentrations were significantly higher than at all of the other sites. The greater orthophosphate concentrations in Little River tributary may be due to 
applications of fertilizers associated with residential and golf-course land uses.

\section{Pesticides}

Water samples for analyses of selected pesticides were collected in the spring and early summer of water years 1996 through 1998 at Mountain Creek (site 6T), Little River tributary (site 8T), and Flat River tributary (site 1T). A total of 119 different pesticides were tested; of these, 12 were detected at concentrations that exceeded the laboratory reporting levels (table 9). Applications of chemicals associated with the operation and maintenance of the golf course occurred during most of the year in 1997 and 1998 (D. Lowe, Manager, Treyburn Golf Course, written commun., 1998). In figure 14, samplecollection data are shown relative to application periods. Sample collections coincided best with herbicide application periods. Only the sample collected on June 19, 1998, coincided with recent applications of insecticides and fungicides. Laboratory reporting levels vary, depending on the compound. Although waterquality standards have not been established for most of these pesticides, North Carolina has established a $100-\mu \mathrm{g} / \mathrm{L}$ limit for 2,4-D in waters classified as water supply (WS-I to WS-IV). This limit was not exceeded in any of the samples analyzed for this study.

All of the pesticides were detected in low concentrations at the three Treyburn sites. These same pesticides were detected in water draining golf courses in Florida at similar concentrations - atrazine, less than $1.5 \mu \mathrm{g} / \mathrm{L}$; simazine, less than $38 \mu \mathrm{g} / \mathrm{L}$; and pronamide, less than $1 \mu \mathrm{g} / \mathrm{L}$ (Swancar, 1996). Little River tributary had the greatest number of pesticides (10 of 11 different compounds). This is also where the highest concentrations were detected, except for atrazine and 2,4-D, which were detected in greater concentrations in Mountain Creek. Five of six samples collected at Little River tributary had detectable concentrations of simazine, atrazine, and pendimethalin - all herbicides that are used to control weeds in crops or turf.

Metolachlor and atrazine, both of which are used to control weeds in crops, were detected five out of six times at Mountain Creek. Only three compounds were detected in Flat River tributary - metolachlor, atrazine, and alachlor - and each was detected once (table 9). Of these, alachlor and metolachlor were detected at about the same maximum concentration at all three sites; atrazine was detected at a much lower concentration at Flat River tributary than at the other two sites.

Table 9. Concentrations of pesticides that exceeded the laboratory reporting level in six stream samples collected at each of three sites in the Treyburn development study area, water years 1996-98

$[\mu \mathrm{g} / \mathrm{L}$, microgram per liter; LRL, laboratory reporting level; <, less than]

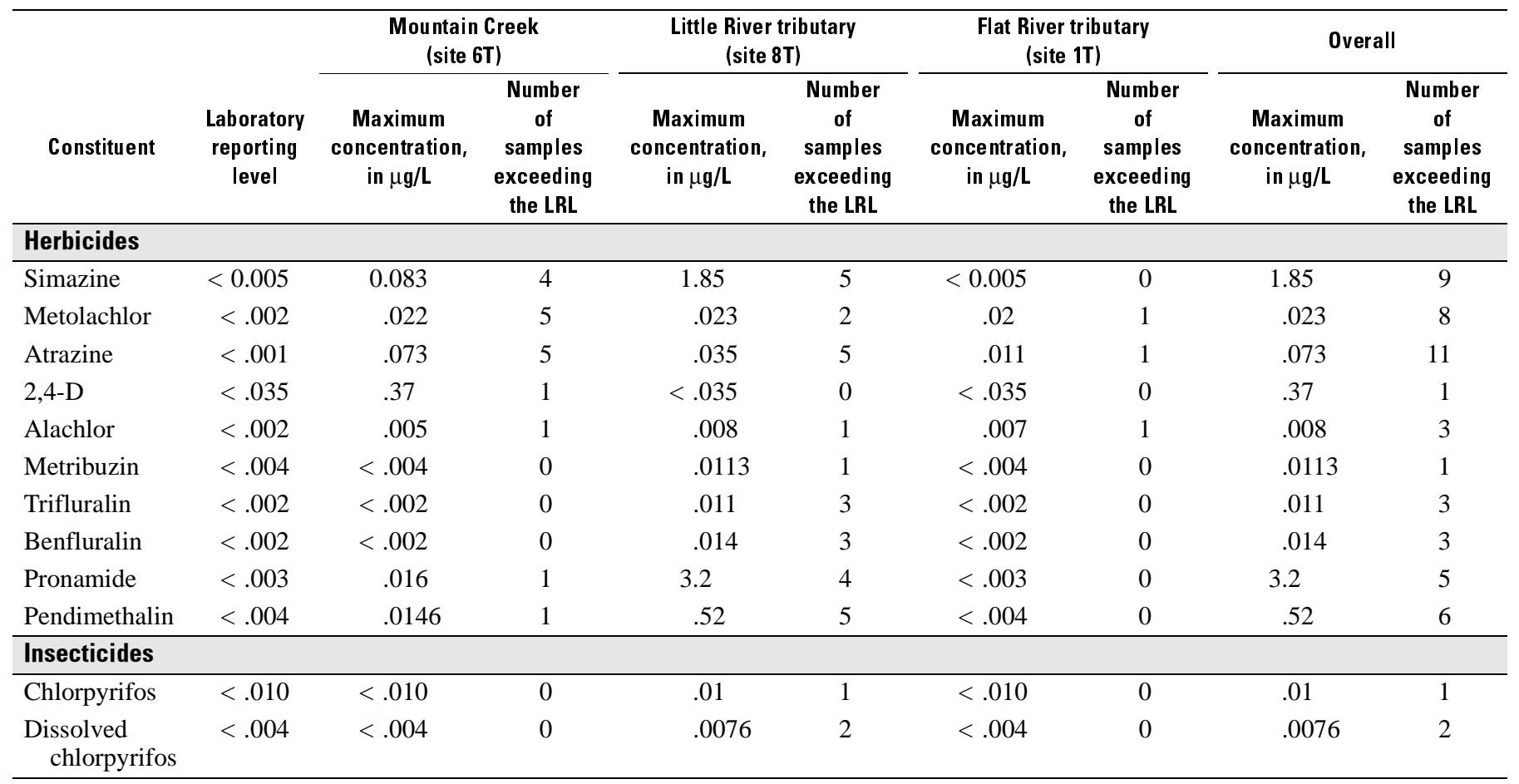




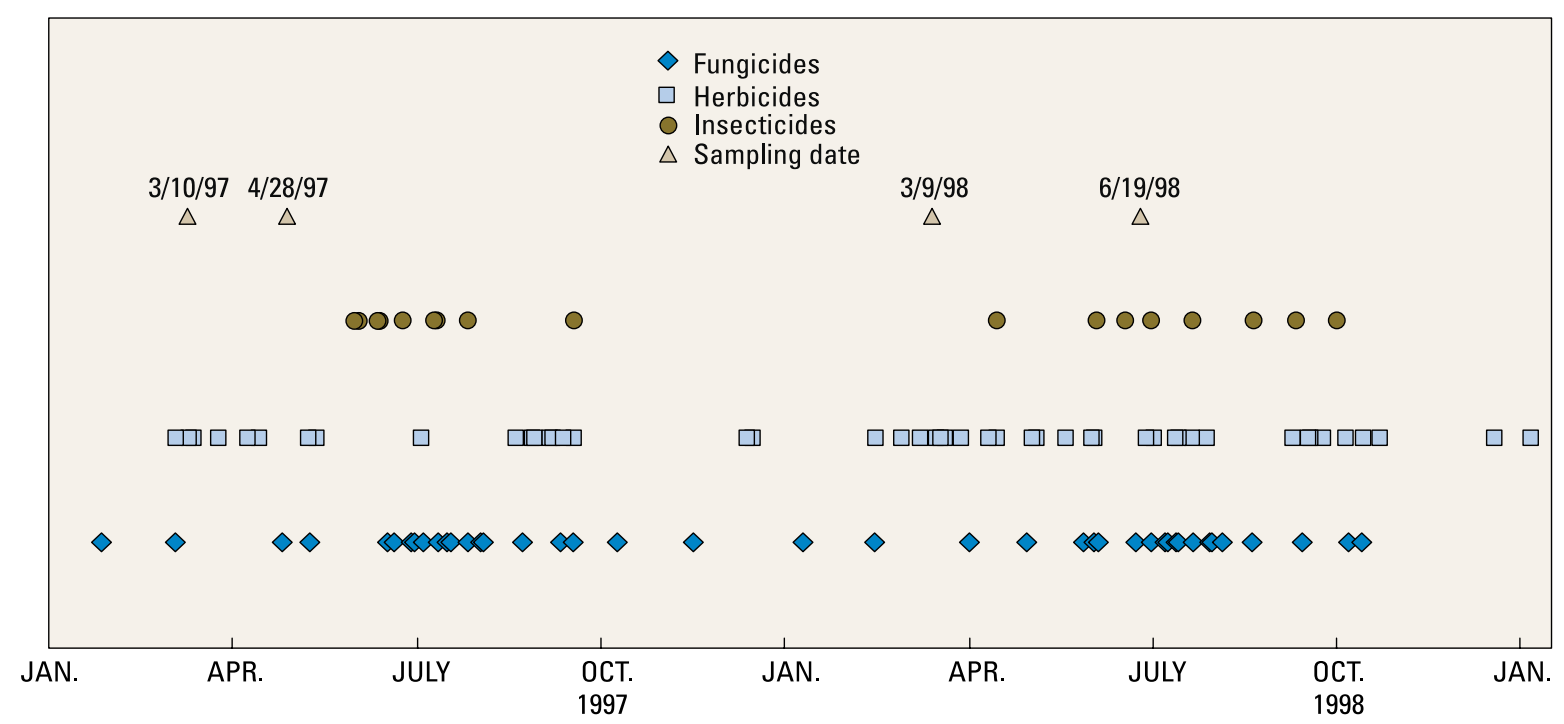

Figure 14. Time line of the application dates for fungicides, herbicides, and insecticides on the Treyburn Golf Course within the Little River tributary drainage basin, and pesticide sampling dates for 1997-98.

\section{Benthic Macroinvertebrates}

Benthic macroinvertebrates are relatively longlived stream inhabitants that have proven to be useful indicators of water-quality conditions. In contrast to chemical measures of water quality, macroinvertebrates integrate the effects of multiple stresses (for example, land-use changes, chemical contamination, habitat destruction, and sedimentation) over time and provide a broad measure of their aggregate effects. Benthic macroinvertebrates are used by 44 States to assess the conditions of streams and rivers (Davis and others, 1996) based on various characteristics (metrics) of invertebrate abundance and taxonomic composition (richness). A variety of multimetric indices (combinations of community metrics, such as taxa richness, EPT richness, tolerance groupings, and functional group abundance) have been developed to assess water quality (Merritt and Cummins, 1996; Barbour and others, 1999). The NCBI developed by the NCDWQ (Lenat, 1988) was a pioneering effort in the development of macroinvertebrate-based water-quality assessment programs and has been used to rate water-quality conditions in North Carolina for almost 15 years.

Consideration of the timing of benthic invertebrate sampling is important when interpreting results because water-quality indices may require seasonal adjustments. Sampling is best timed to coincide with the period when the majority of the benthic invertebrate community is nearing the end of the aquatic phase of their life cycle and are easiest to identify. Water temperature and current and antecedent stream-discharge conditions also are important factors. Since some of the streams sampled for this study drain very small watersheds that do not flow during summer months, the optimal sampling time is winter and spring. Samples for most sites were collected during February 13-15, 1995, when streamflow conditions were near the long-term median at Flat River at Bahama (site 5T) and had been stable for several weeks. Samples for Little River tributary sites 8T and 8TB were collected on February 21, 1995, about 1 week following a runoff event. Stream temperatures ranged from 0.5 to 9 degrees Celsius $\left({ }^{\circ} \mathrm{C}\right)$. Seasonality tests performed by the NCDWQ indicate that seasonal adjustments were not needed for the EPT taxa-richness metric. The NCBI values, however, were adjusted for seasonality $(+0.1)$ before applying the biocriteria (D.R. Lenat, North Carolina Division of Water Quality, written commun., 1995).

The distribution of benthic invertebrates also is influenced by their position within the river basin (Vannote and others, 1980). That is, the assemblage of invertebrates in small, heavily shaded headwater streams is expected to be different from the assemblage of invertebrates in more open, midsize streams, which in turn is expected to be different from the assemblage of invertebrates in deep, turbid, large streams within the same river basin. Consequently, it is appropriate to analyze the streams in this study by dividing them into three groups based on stream size: (1) small streams (sites $1 \mathrm{~T}, 2 \mathrm{~T}, 3 \mathrm{~T}, 8 \mathrm{~T}$, and $8 \mathrm{~TB}$, fig. 2) that drain basins of less than $2 \mathrm{mi}^{2}$, (2) midsize streams (site 6T) that drain basins 
of 5-10 $\mathrm{mi}^{2}$, and (3) rivers (sites 4T, 5T, 10T, and 11T) that drain basins of $75-150 \mathrm{mi}^{2}$. The differences in invertebrate assemblages between small streams and rivers is expected to be even larger than normal because small streams in this ecoregion (Carolina slate belt) may stop flowing during summer months (D.R. Lenat, North Carolina Division of Water Quality, written commun., 1995).

\section{Invertebrate Community Characteristics}

Over 230 taxa were identified from 10 sites (Appendix 2A, B). Total taxa richness at each site (richness based on a composite of RTH, DTH, and QMH) ranged from 49 to 108 (table 10). River sites tended to have higher total taxa richness $(91-108)$ than did the small, intermittent streams (49-84) or the midsize stream (85). Intermittent streams represent fairly hostile environments for most aquatic organisms, particularly for long-lived organisms, such as large stoneflies, dragonflies, dobsonflies, and molluscs. Consequently, invertebrates in these streams must have relatively short life cycles that are synchronized with seasonal flows or that are adapted to withstand seasonal dry periods. This limits the kinds of invertebrates that can survive in these habitats and accounts for the lower taxa richness observed in these streams.

Richest targeted habitat (RTH) samples typically were more than twice as rich as DTH samples (table 10) and represented from 51 to 75 percent of the taxa found at each site (mean of 62 percent). In contrast, the DTH samples represented only 3 to 56 percent of the taxa at each site (mean of 21.5 percent). Depositional areas tend to support a lower diversity of organisms because of the shifting nature of fine sediments and the lack of suitable microhabitats generally found in riffle areas. The assemblage of invertebrates found in the small, intermittent streams differed in several respects from the assemblage of invertebrates found in large rivers. Twentyeight taxa were found in rivers but not in the small streams, whereas only six taxa were restricted to small streams (table 11). The midsize stream (Mountain Creek) had representatives of both small and large streams. The average tolerance value of the taxa restricted to small streams (6.53) was higher than that of large rivers (4.42), indicating that the taxa restricted to small streams generally were more tolerant of disturbance than were taxa restricted to large rivers. This difference is consistent with the rigors of living in the highly variable hydrologic environment of intermittent streams.

Sites 1T (Flat River tributary) and 2T (Eno River tributary) were chosen to represent undeveloped and industrial land uses, respectively. Both sites had low taxa richness ( 55 and 49 , respectively) compared to other small streams (65-84, table 10). The streambeds at sites $1 \mathrm{~T}$ and $2 \mathrm{~T}$ consist of sand and small gravel, whereas cobble and gravel substrates are dominant at the other sites. Many invertebrates prefer a mix of large (cobble) and small (gravel/sand) substrates and are unable to live on shifting substrates, such as sand and small gravel. Assuming no other differences, the similar environmental settings at sites $1 \mathrm{~T}$ and $2 \mathrm{~T}$ lead to the expectation that invertebrate assemblages would be comparable and the number of taxa fewer than that of small streams with larger (cobble/gravel) substrates. The contrast between the undeveloped site 1T and the industrial site $2 \mathrm{~T}$ is interesting in that the industrial site lacked many of the mayfly taxa that are present at the undeveloped site. Mayflies are very sensitive to metals contamination, and their absence may indicate an effect of development. Supporting chemical information is not available for site $2 \mathrm{~T}$, however, so additional study would be needed to substantiate this possibility.

The remaining small-stream sites (3T, 8T, and 8TB) are all tributaries of the Little River (fig. 2). Site 3T (Little River tributary near Durham) represents a combination of forested and residential lands, whereas sites $8 \mathrm{~T}$ and $8 \mathrm{~TB}$ (site $8 \mathrm{~T}$ is downstream and site $8 \mathrm{~TB}$ is upstream from the confluence with an unnamed tributary) represent a combination of residential and recreational (golf course) development (table 1). The sites represented by a mixture of golf course and residential land use (sites $8 \mathrm{~T}$ and $8 \mathrm{~TB}$ ) tended to support more different types of sensitive invertebrates (that is, EPT taxa, which are representatives of Ephemeroptera, Plecoptera, and Trichoptera) than did the site with a mixture of forested and residential sites (3T), though the abundances of EPT taxa were similar (table 12). Generally, sites with a higher percentage of undisturbed forest (site 3T) would be expected to have a greater diversity of EPT taxa than disturbed sites (for example, sites 8T and 8TB). In this case, land-use effects were not evident.

The invertebrate assemblage at Little River near Weaver (site 10T) was different from the other river sites. Several of the mayflies (Isonychia, Stenonema modestum), stoneflies (Isoperla namata, Isoperla transmarina, Strophopteryx, Taeniopteryx), caddis flies (Chimarra, Hydropsyche venularis), beetles (Dubiraphia, Macronychus glabratus, Optioservus, Psephenus herricki, Stenelmis), odonates (Enallagma), and megalopterans (Corydalus cornutus) commonly found at river sites (Appendix 2) were entirely absent from this Little River site or were present only at very low abundances. Consequently, this site had fewer large, pollution-intolerant invertebrates (for example, EPT taxa) 


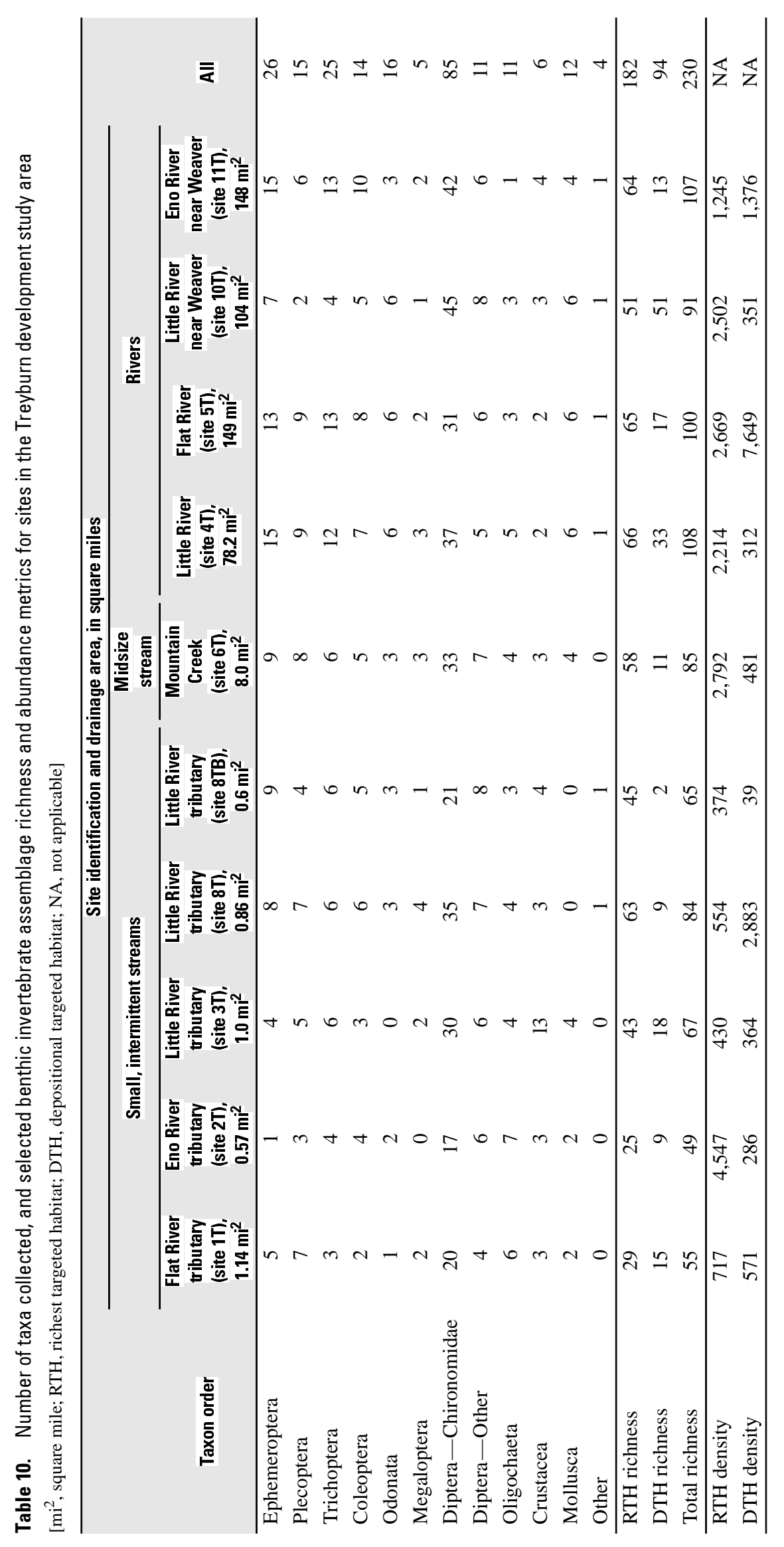


Table 11. Number of sites where benthic macroinvertebrate taxa were collected at small, midsize, and river sites in the Treyburn development study area, and the tolerance value for each taxa

[—, tolerance value not determined; spp., species undetermined; NA, not applicable]

\begin{tabular}{|c|c|c|c|c|}
\hline \multirow[b]{2}{*}{ Taxon } & \multirow[b]{2}{*}{$\begin{array}{c}\text { Tolerance } \\
\text { value }\end{array}$} & \multicolumn{3}{|c|}{ Number of sites where taxa occurred } \\
\hline & & $\begin{array}{c}\text { Small } \\
\text { streams }\end{array}$ & $\begin{array}{c}\text { Midsize } \\
\text { streams }\end{array}$ & Rivers \\
\hline \multicolumn{5}{|l|}{ Ephemeroptera } \\
\hline Eurylophella enoensis & - & 0 & 0 & 3 \\
\hline Isonychia spp. & 3.8 & 0 & 1 & 3 \\
\hline Paraleptophlebia spp. & 1.2 & 3 & 1 & 0 \\
\hline Anthopotamus & 1.6 & 0 & 0 & 3 \\
\hline Stenonema femoratum & 7.5 & 3 & 1 & 0 \\
\hline Stenonema modestum & 5.8 & 0 & 1 & 4 \\
\hline Stenacron interpunctatum & 7.1 & 0 & 1 & 4 \\
\hline \multicolumn{5}{|l|}{ Plecoptera } \\
\hline Acroneuria abnormis & 2.2 & 0 & 1 & 3 \\
\hline Isoperla namata (gr) & 1.8 & 0 & 1 & 3 \\
\hline Taeniopteryx spp. & 5.8 & 0 & 0 & 4 \\
\hline \multicolumn{5}{|l|}{ Trichoptera } \\
\hline Hydropsyche venularis & 5.3 & 0 & 0 & 3 \\
\hline Hydroptila spp. & 6.2 & 0 & 0 & 3 \\
\hline Macrostemum spp. & 3.6 & 0 & 0 & 3 \\
\hline Micrasema rusticum & 0.0 & 0 & 0 & 3 \\
\hline \multicolumn{5}{|l|}{ Coleoptera } \\
\hline Berosus spp. & 8.6 & 0 & 0 & 3 \\
\hline Macronychus glabratus & 4.7 & 0 & 0 & 4 \\
\hline Microcylloepus pusillus & 2.1 & 0 & 0 & 3 \\
\hline \multicolumn{5}{|l|}{ Odonata } \\
\hline Enallagma spp. & 9.0 & 0 & 0 & 3 \\
\hline Neurocordulia obsoleta & 3.3 & 0 & 0 & 3 \\
\hline \multicolumn{5}{|l|}{ Diptera } \\
\hline \multicolumn{5}{|l|}{ Chironomidae } \\
\hline Brillia spp. & 5.2 & 0 & 0 & 3 \\
\hline Cricotopus bicinctus: C/O sp.1 & 8.7 & 0 & 0 & 4 \\
\hline Cricotopus/Orthocladius sp.60 & - & 0 & 1 & 3 \\
\hline Eukiefferiella devonica (gr, E sp. 2) & 2.6 & 0 & 0 & 3 \\
\hline Nanocladius downesi & 2.6 & 0 & 0 & 3 \\
\hline Natarsia spp. & 10.0 & 3 & 0 & 0 \\
\hline Parakiefferiella spp. & - & 0 & 0 & 3 \\
\hline Potthastia longimanus & 7.4 & 0 & 1 & 3 \\
\hline Rheocricotopus robacki & 7.7 & 0 & 1 & 4 \\
\hline \multicolumn{5}{|l|}{ Other } \\
\hline Hexatoma spp. & 4.7 & 4 & 0 & 0 \\
\hline Simulium spp. & 4.4 & 0 & 1 & 4 \\
\hline \multicolumn{5}{|l|}{ Oligochaeta } \\
\hline Spirosperma nikolskyi & 7.7 & 3 & 1 & 0 \\
\hline \multicolumn{5}{|l|}{ Crustacea } \\
\hline Cambarus spp. & 8.1 & 3 & 1 & 0 \\
\hline Hyalella azteca & 7.9 & 0 & 0 & 4 \\
\hline \multicolumn{5}{|l|}{ Pelecypoda } \\
\hline Corbicula fluminea & 6.3 & 0 & 0 & 4 \\
\hline Average tolerance values: & NA & 6.53 & 4.98 & 4.42 \\
\hline
\end{tabular}




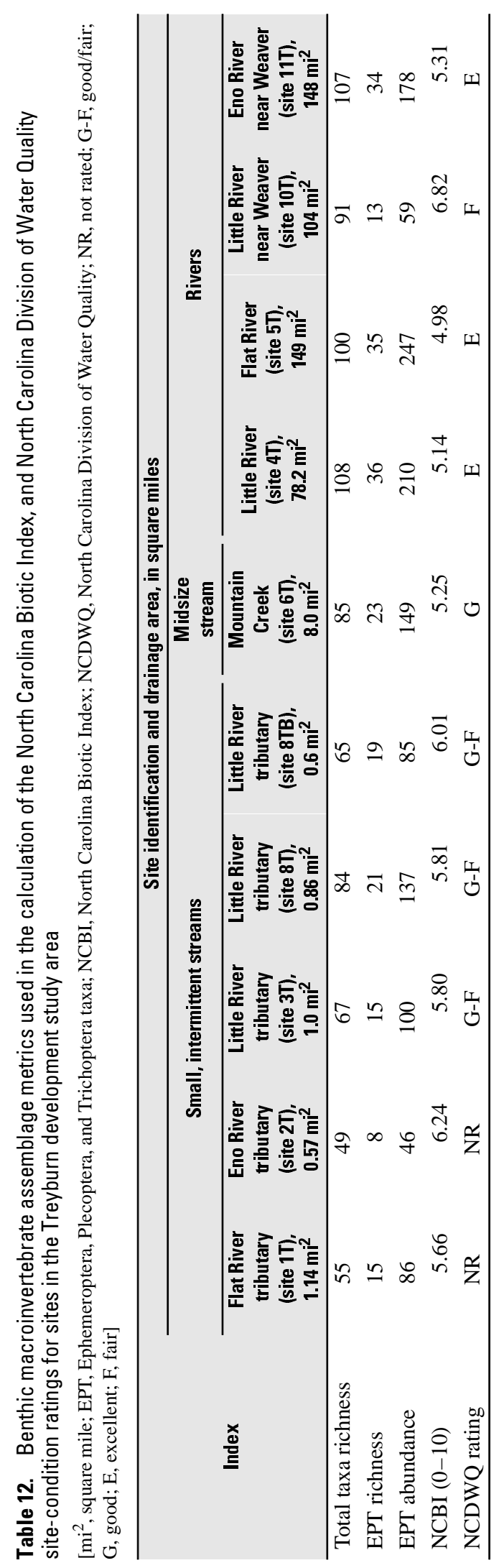


than did other large river sites and more small, short-lived insects, such as midges. The Little River site is the only river site located downstream from a reservoir and the only site with sand as the dominant substrate and snags as the RTH. Substrate differences and the effects of reservoir releases on flows, food resources, and temperature probably are the key reasons why many of the long-lived invertebrates that are sensitive to disturbance are missing from this site.

Density of invertebrates (Appendix 2) varied widely among sites and sample types. Organism density in RTH samples collected from small, intermittent streams typically ranged from 400 to 700 organisms per square meter (organisms $/ \mathrm{m}^{2}$ ). Site $2 \mathrm{~T}$ was a notable exception, as density was greater than 4,500 organisms $/ \mathrm{m}^{2}$. In general, organism density and richness were much greater in the RTH samples than in the DTH samples, which is indicative of the relatively severe conditions faced by organisms living in relatively unstable, fine-grained, depositional habitats where exposure to sediment-borne contaminants probably is greater than in riffles.

Several metrics were used to classify each stream based on the number and type of macroinvertebrates collected (tables 10, 12). Streams that are less stressed, especially by chemical pollutants, tend to have diverse macroinvertebrate communities, and these communities are dominated by species that are intolerant to chemical pollutants. Total taxa richness is the total number of different taxa identified at the sites, and values at individual sites ranged from 49 to 108 (table 10). EPT richness and abundance are based on the number of different taxa and the numbers of individual organisms, respectively, found in the groups Ephemeroptera, Plecoptera, and Trichoptera. These groups are intolerant of chemical pollutants, and their presence and greater numbers are positive indications of stream water quality.

\section{Community Condition}

The NCDWQ calculated EPT and NCBI (table 12) for each site (Lenat, 1988; North Carolina Division of Water Quality, 1997). Water-quality-condition ratings based on EPT and NCBI could be assigned to all sites except sites $1 \mathrm{~T}$ and $2 \mathrm{~T}$, which were not ranked because they lacked the types of stream fauna typically found at sites where the NCBI is applied (D.R. Lenat, North Carolina Division of Water Quality, written commun. 1995). Even though the NCDWQ rated water-quality conditions for the other very small streams (sites 3T, 8T, $8 \mathrm{~TB}$ ), these ratings probably are adversely affected by the reduction in total taxa richness and EPT taxa richness associated with intermittent flows (D.R. Lenat, North
Carolina Division of Water Quality, written commun., 1995). The NCDWQ is developing methods to more accurately assess water-quality conditions in intermittent streams (Dave Penrose, North Carolina Division of Water Quality, oral commun., 2000). Consequently, the waterquality ratings for sites $3 \mathrm{~T}, 8 \mathrm{~T}$, and $8 \mathrm{~TB}$ should be considered preliminary and subject to revision.

Ephemeroptera, Plecoptera, and Trichoptera (EPT) taxa richness ranged from 8 to 36 , and the NCBI ranged from 4.98 (excellent) to 6.82 (fair) for streams sampled in this study (table 12). All river sites were rated as excellent, except for Little River (site 10T), which was rated as fair. The Little River site did not have many of the invertebrate taxa that are indicative of good water-quality conditions and that were found at the other river sites. This probably is associated with the influence of Little River Reservoir, which affects temperature, substrate, food resources, and flows at this site. The midsize stream (Mountain Creek, site 6T) was rated as good. Mountain Creek is affected by urban development and agriculture, which probably account for the lower water-quality rating. The excellent ratings for Little River site $4 \mathrm{~T}$ and Flat River site 5T reflect the predominance of intact forests in these drainages and the conversion of agricultural lands to forest. These ratings would be expected to decrease as urbanization encroaches in these basins. The excellent rating for the Eno River site (11T) is indicative of the conservation measures that have been directed at the Eno River over the last few decades, including diversion of wastewater discharges elsewhere (North Carolina Department of Environment and Natural Resources, 1999, p. 116). The intermittent streams (Little River tributary sites 3T, 8T, and 8TB) were all rated good to fair. Given the likelihood that intermittent flows in these streams reduce the values of the metrics used to rate them, the actual conditions at these sites may be better than indicated here. Methods to more accurately evaluate the biological condition of intermittent streams are under development at the NCDWQ (D. Penrose, North Carolina Division of Water Quality, oral commun., 2000).

The NCBI and site ratings were derived from a composite of RTH, DTH, and QMH samples collected by using USGS NAWQA Program protocols (Cuffney and others, 1993). These procedures are somewhat different from those used by the North Carolina Division of Water Quality (1997). The comparability of NCBI values derived from the USGS and NCDWQ methods were addressed by comparing index values for four sites (4T, 5T, 6T, and 11T) sampled in this study that also are routinely monitored by the NCDWQ. Results from the NCDWQ monitoring were available for both winter and summer sampling, and in all cases, the results obtained by 
using the USGS protocols were similar to those obtained by using the NCDWQ techniques (fig. 15). Consequently, the metrics and condition ratings reported here can be compared to those of the NCDWQ.

\section{Patterns in Invertebrate Distributions and Physical and Chemical Factors}

Indirect gradient analysis was used to uncover patterns in the distribution of invertebrates and examine the relations between these patterns and physical and chemical site characteristics. Detrended correspondence analysis (DCA) was used to identify patterns in the data and extract uncorrelated axes that maximize the amount of variability within the community data that is explained by each axis. This method is analogous to regression, except that ordination works with multiple dependent and independent variables. Typically, two uncorrelated axes are extracted in ordination, and these axes are used to provide a simple two-dimensional visual representation of the pattern in invertebrate distributions. In these ordination diagrams, sites are positioned along each axis based on the community composition of each site. The position of the site along the axis is referred to as the site score. This score represents the relative position of each site along a derived environmental gradient, such that sites that are located close to one another have similar invertebrate assemblages and sites that are located far apart have very different assemblages. Physical and chemical variables measured at each site can then be related to these site scores to determine if they are correlated with the differences among sites as determined from the differences in community structure among sites. In this fashion, it is possible to gain insight into the physical and chemical factors that are important in determining the distribution of benthic macroinvertebrates.

Separate DCA ordinations were applied to the quantitative data (RTH and DTH samples) and to the composite (QMH) sample expressed as presence or absence of each taxon (fig. 16). Abundance data were log transformed $(\log [\mathrm{X}+1])$ before analysis, and rare taxa were downweighted in the analysis conducted with a multivariate statistical program (MVSP; Kovich, 1998). The results for the RTH (fig. 16A) and QMH (fig. 16B) samples reveal a similar pattern along the first axis, with small, intermittent streams on the left side of the axis, large rivers on the right, and the midsize stream (site 6T) between the two. The majority of the variability in the species data is accounted for by the first axis ( 27 percent for RTH and 28 percent for QMH) and much less in the second axis ( 8 and 14 percent, respectively). The amount of variability explained by these axes is substantially greater than what might be expected if species distributions were totally random; that is, 100 percent divided by the number of taxa (182 and 239, respectively). The first axes also have eigenvalues (RTH, 0.47; QMH,

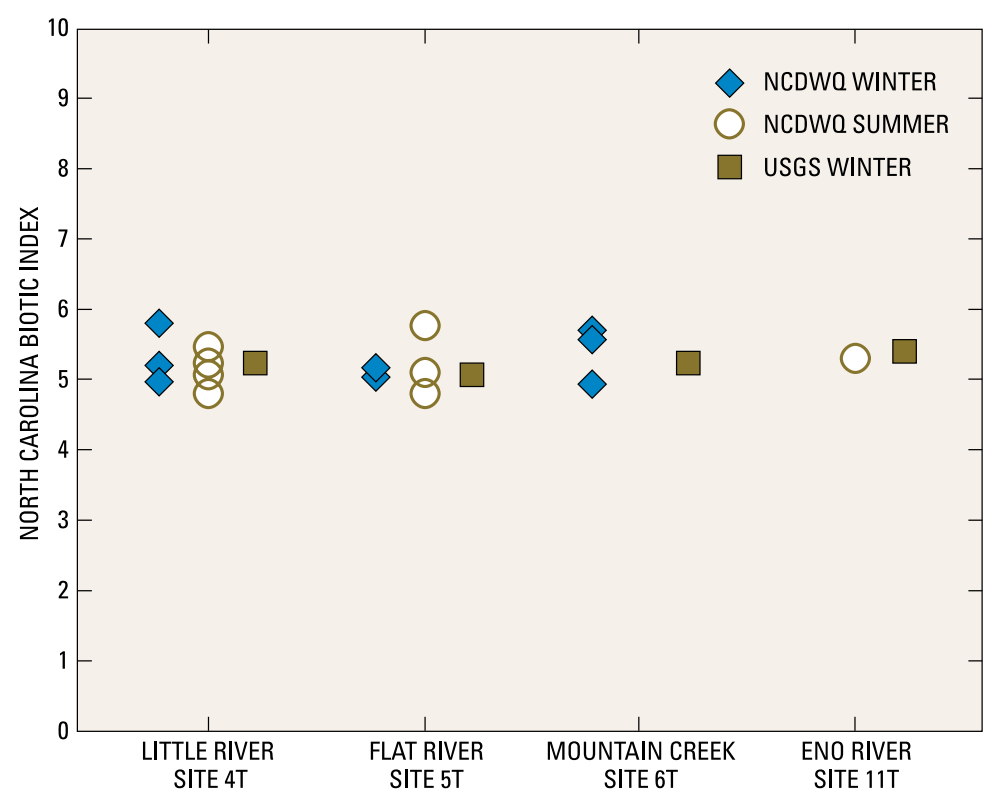

Figure 15. North Carolina Biotic Index (NCBI) values obtained by the U.S. Geological Survey and by the North Carolina Division of Water Quality for sites in the Treyburn development study area. 


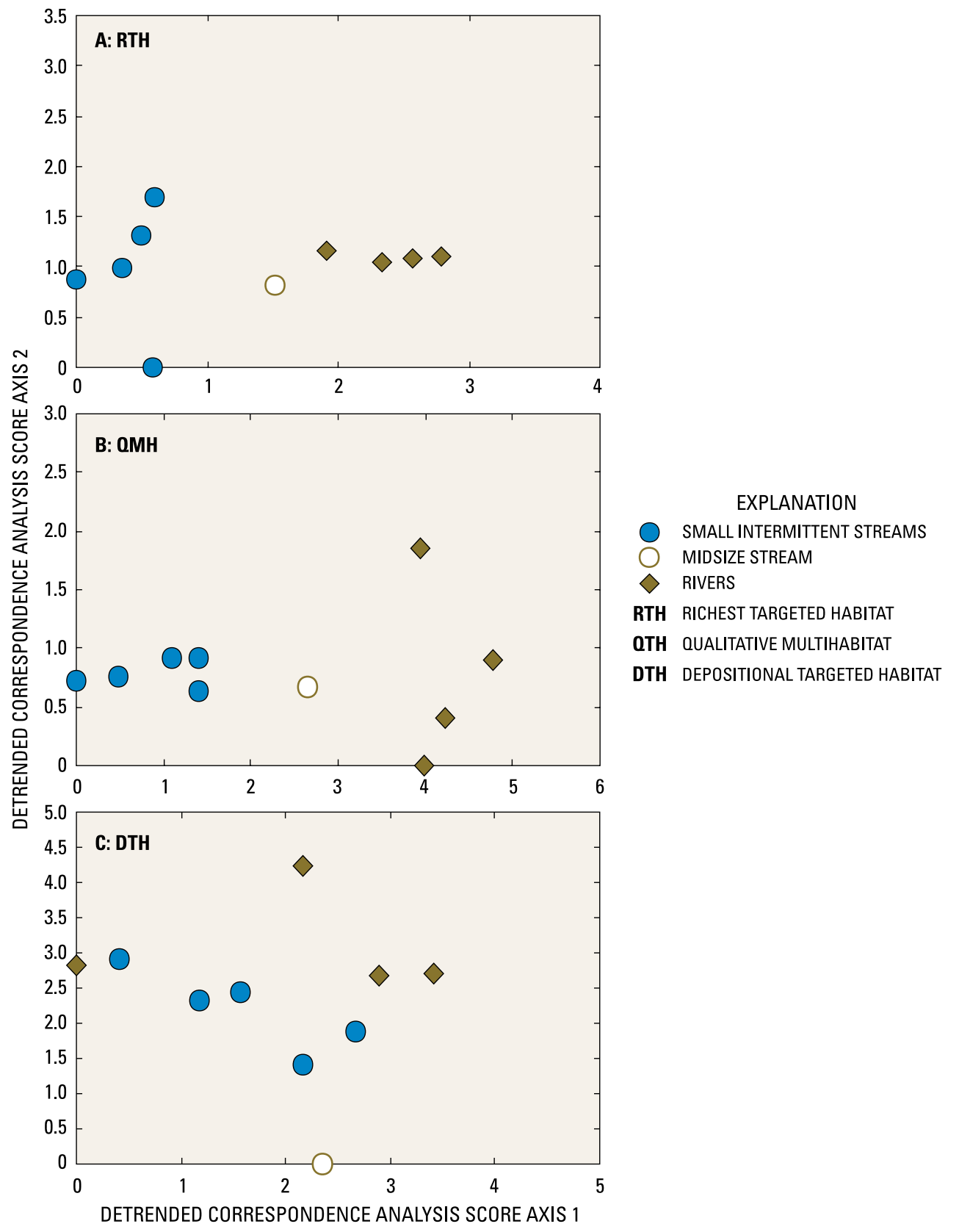

Figure 16. Relations among Treyburn development study area sites, based on (A) richest targeted habitat (RTH), (B) qualitative multihabitat $(\mathrm{OMH})$, and $(\mathrm{C})$ depositional targeted habitat (DTH) samples.

0.37) indicative of relatively important axes (ter Braak, 1987). Consequently, the first axis (environmental gradient) summarizes a good portion of the structure in the invertebrate data. In contrast, the second axes, which have low eigenvalues ( 0.14 and 0.18 , respectively), explain little of the variability in the data ( 8 and 14 percent, respectively) and probably do not provide a good separation of taxa along this axis (ter Braak, 1987). Consequently, the majority of the pattern in the RTH and
QMH ordinations is explained by the first axis of the ordination. The first axis of the DTH ordination diagram (fig. 16C) did not show the same separation between small, intermittent streams and rivers, and the first two axes explained 18 and 9 percent of the variability, though the eigenvalues (axis 1:0.58; axis 2:0.29) indicated that both axes provided a good separation among taxa. The community ordinations suggest that the organisms associated with the DTH samples probably responded to 
a different set of environmental variables than the organisms associated with RTH and QMH samples. Indirect gradient analysis (correlation of environmental factors with site scores from DCA) was used to compare and contrast these relations.

Correlation (Spearman's rho) of physical and chemical site variables with axes 1 and 2 site scores suggests that the dominant environmental gradient (axis 1) determining invertebrate distributions for both RTH and QMH samples is associated with just 14 of the 60 site variables measured in this study (table 13). Total phosphorus, temperature, nitrite plus nitrate, and 11 variables associated with habitat or sample-collection depths or velocities were significantly correlated with axis 1 site scores. Nine of these variables (nitrite plus nitrate, temperature, mean bank angle, mean bankfull width, mean channel width, channel width-to-depth ratio, mean water depth at RTH sampling sites, mean velocity associated with DTH samples, and channel width at time of RTH sampling) also were significantly correlated with drainage-basin area (table 13), an indicator of stream size. Therefore, the dominant factor influencing organism distribution in this data set is drainage-basin area, which controls several of the chemical and habitat characteristics as well.

The second axes of the RTH and QMH sample ordinations were distinctly different from one another (table 13) and less interpretable. None of the physical and chemical variables measured in this study were significantly correlated with the second axis of the QMH ordination. In contrast, calcium, magnesium, $\mathrm{pH}$, hardness, alkalinity, organic nitrogen, ammonia plus organic nitrogen, dissolved organic carbon, and conductivity were significantly correlated with the second axis of the RTH ordination. Because of the low eigenvalues associated with the second axes, however, it probably is not appropriate to place too much importance on the interpretation of these axes.

Table 13. Correlations between physical and chemical variables and drainage-basin size, and ordination site scores for macroinvertebrate samples from sites in the Treyburn development study area

[DCA, detrended correspondence analysis; RTH, richest targeted habitat; QMH, qualitative multihabitat; DTH, depositional targeted habitat; rho, Spearman's rho; n, number; rho values in bold are statistically significant at $p \leq 0.05 ; \mathrm{mg} / \mathrm{L}$, milligram per liter; NA, not applicable]

\begin{tabular}{|c|c|c|c|c|c|c|c|c|}
\hline \multirow[b]{3}{*}{ Eigenvalues } & \multicolumn{6}{|c|}{ Ordination (DCA) site scores } & \multirow{3}{*}{$\begin{array}{c}\text { Drainage } \\
\text { basin } \\
\text { area }\end{array}$} & \\
\hline & \multicolumn{2}{|c|}{ RTH } & \multicolumn{2}{|c|}{$\mathbf{0 M H}$} & \multicolumn{2}{|c|}{ DTH } & & \\
\hline & $\begin{array}{c}\text { Axis } 1 \\
0.47\end{array}$ & $\begin{array}{c}\text { Axis } 2 \\
0.14\end{array}$ & $\begin{array}{c}\text { Axis } 1 \\
0.37\end{array}$ & $\begin{array}{c}\text { Axis 2 } \\
0.18\end{array}$ & $\begin{array}{c}\text { Axis } 1 \\
0.58\end{array}$ & $\begin{array}{c}\text { Axis 2 } \\
0.29\end{array}$ & & \\
\hline Variable & rho & rho & rho & rho & rho & rho & rho & $\mathbf{n}$ \\
\hline Calcium & 0.285 & 0.812 & 0.223 & -0.042 & 0.126 & -0.176 & -0.153 & 9 \\
\hline Magnesium & .395 & .756 & .342 & -.084 & .202 & -.277 & -.068 & 9 \\
\hline Sulfate & -.084 & .420 & -.110 & .521 & -.067 & .109 & -.444 & 9 \\
\hline Chloride & .251 & .427 & .231 & .377 & .176 & -.025 & -.221 & 9 \\
\hline Total nitrogen & .613 & -.400 & .645 & -.145 & .162 & .349 & .762 & 9 \\
\hline Total phosphorus & .749 & -.264 & .782 & -.077 & .451 & .230 & .658 & 9 \\
\hline Suspended sediment & .186 & -.254 & .187 & -.627 & -.322 & .237 & .672 & 9 \\
\hline Conductivity & 619 & .695 & .584 & .042 & .326 & -.042 & .136 & 9 \\
\hline $\mathrm{pH}$ & .504 & .701 & .468 & .034 & .111 & -.094 & .070 & 9 \\
\hline Temperature & .887 & .059 & .903 & -.460 & .310 & .243 & .800 & 9 \\
\hline Dissolved oxygen (mg/L) & -.458 & .068 & -.485 & .068 & .085 & -.746 & -.466 & 9 \\
\hline Dissolved oxygen (\% saturation) & .025 & .059 & .008 & -.025 & .395 & -.613 & .017 & 9 \\
\hline Color & -.017 & -.561 & .021 & -.410 & -.243 & .393 & .409 & 9 \\
\hline Hardness & .335 & .778 & .282 & .025 & .226 & -.259 & -.119 & 9 \\
\hline Sodium & .485 & .527 & .466 & .276 & .293 & -.142 & .034 & 9 \\
\hline Potassium & .545 & .400 & .517 & .009 & .145 & -.009 & .173 & 9 \\
\hline Alkalinity & .418 & .795 & .366 & -.059 & .192 & -.209 & -.051 & 9 \\
\hline Fluoride & 619 & .510 & 609 & .025 & -.025 & .176 & .374 & 9 \\
\hline Silicon & -.184 & .46 & -.239 & -.192 & -.293 & -.427 & -.153 & 9 \\
\hline Dissolved solids & .101 & .462 & .072 & .462 & .034 & -.168 & -.197 & 9 \\
\hline
\end{tabular}


Table 13. Correlations between physical and chemical variables and drainage-basin size, and ordination site scores for macroinvertebrate samples from sites in the Treyburn development study area-Continued

[DCA, detrended correspondence analysis; RTH, richest targeted habitat; QMH, qualitative multihabitat; DTH, depositional targeted habitat; rho, Spearman's rho; n, number; rho values in bold are statistically significant at $p \leq 0.05 ; \mathrm{mg} / \mathrm{L}$, milligram per liter; NA, not applicable]

\begin{tabular}{|c|c|c|c|c|c|c|c|c|}
\hline \multirow[b]{3}{*}{ Eigenvalues } & \multicolumn{6}{|c|}{ Ordination (DCA) site scores } & \multirow{3}{*}{$\begin{array}{c}\text { Drainage } \\
\text { basin } \\
\text { area }\end{array}$} & \\
\hline & \multicolumn{2}{|c|}{ RTH } & \multicolumn{2}{|c|}{ OMH } & \multicolumn{2}{|c|}{ DTH } & & \\
\hline & $\begin{array}{c}\text { Axis } 1 \\
0.47\end{array}$ & $\begin{array}{c}\text { Axis } 2 \\
0.14\end{array}$ & $\begin{array}{c}\text { Axis } 1 \\
0.37\end{array}$ & $\begin{array}{c}\text { Axis 2 } \\
0.18\end{array}$ & $\begin{array}{c}\text { Axis } 1 \\
0.58\end{array}$ & $\begin{array}{c}\text { Axis } 2 \\
0.29\end{array}$ & & \\
\hline Variable & rho & rho & rho & rho & rho & rho & rho & $\mathbf{n}$ \\
\hline Nitrite plus nitrate & 0.736 & -0.326 & 0.769 & -0.176 & 0.293 & 0.243 & 0.885 & 9 \\
\hline Ammonia nitrogen & -.070 & -.244 & -.070 & -.104 & -.627 & .470 & .168 & 9 \\
\hline Organic nitrogen & -.033 & -.828 & .029 & -.008 & .059 & .159 & .238 & 9 \\
\hline Ammonia plus organic nitrogen & -.067 & -.778 & -.013 & .008 & -.092 & .293 & .221 & 9 \\
\hline Orthophosphate & .390 & -.390 & .426 & .220 & .254 & .186 & .310 & 9 \\
\hline Aluminum & .184 & -.377 & .197 & -.561 & -.259 & .226 & .698 & 9 \\
\hline Cobalt & -.143 & .429 & -.143 & -.571 & -.750 & .429 & .286 & 7 \\
\hline Copper & .418 & .042 & .408 & -.276 & -.243 & .427 & .732 & 9 \\
\hline Iron & -.151 & -.594 & -.130 & -.444 & -.477 & .259 & .409 & 9 \\
\hline Lead & .117 & .025 & .097 & -.159 & -.561 & .577 & .323 & 9 \\
\hline Manganese & -.117 & .059 & -.155 & -.326 & -.159 & -.176 & -.323 & 9 \\
\hline Nickel & .184 & .008 & .172 & -.377 & -.410 & .812 & .426 & 9 \\
\hline Dissolved organic carbon & .017 & -.745 & .080 & -.025 & .226 & .226 & .221 & 9 \\
\hline Mean bank angle & -.770 & -.008 & -.803 & -.050 & -.494 & -.176 & -.715 & 9 \\
\hline Mean bank height & .502 & .126 & .492 & -.351 & -.126 & .728 & .749 & 9 \\
\hline Mean bank width & .603 & -.209 & .626 & -.251 & .075 & .644 & .817 & 9 \\
\hline Mean bankfull width & .837 & -.126 & .861 & -.368 & .259 & .377 & .800 & 9 \\
\hline Mean channel width & .954 & .075 & .971 & -.351 & .360 & .109 & .851 & 9 \\
\hline Mean elevation difference & .569 & .092 & .559 & -.385 & -.075 & .678 & .766 & 9 \\
\hline Channel gradient & -.285 & -.561 & -.239 & .151 & .259 & -.276 & -.289 & 9 \\
\hline Mean bankfull depth & .569 & .092 & .559 & -.385 & -.075 & .678 & .766 & 9 \\
\hline Mean cross-section area & .653 & .075 & .643 & -.402 & -.008 & .544 & .834 & 9 \\
\hline Channel width to depth & .921 & .059 & .945 & -.285 & .377 & .142 & .817 & 9 \\
\hline Standard error, bank angle & -.552 & .075 & -.576 & -.084 & -.862 & .527 & -.255 & 9 \\
\hline Standard error, bank height & .184 & .494 & .164 & .033 & -.126 & .762 & .187 & 9 \\
\hline Standard error, bank width & .437 & .403 & .426 & -.227 & -.092 & .840 & .419 & 9 \\
\hline Standard error, bankfull width & .703 & .176 & .693 & -.502 & .025 & .628 & .630 & 9 \\
\hline Standard error, channel width & .703 & .176 & .693 & -.502 & .025 & .628 & .630 & 9 \\
\hline Standard error, elevation difference & .269 & .471 & .245 & -.034 & -.084 & .698 & .222 & 9 \\
\hline Drainage area & .816 & -.043 & .831 & -.166 & .190 & .436 & NA & 10 \\
\hline North Carolina Biotic Index & -.553 & .292 & -.564 & .657 & .122 & .024 & -.585 & 10 \\
\hline Mean depth at RTH sampling sites & .927 & .285 & .912 & -.442 & .152 & .345 & .693 & 10 \\
\hline Mean velocity at RTH sampling sites & .697 & -.188 & .693 & -.588 & -.103 & .345 & .583 & 10 \\
\hline Mean depth at DTH sampling sites & .576 & .515 & .571 & .358 & .648 & .261 & .362 & 10 \\
\hline Mean velocity at DTH sampling sites & .855 & .164 & .845 & -.127 & .285 & .455 & .877 & 10 \\
\hline Channel width at time of RTH sampling & .903 & .345 & .881 & -.430 & .248 & .418 & .791 & 10 \\
\hline $\mathrm{pH}$ at time of RTH sampling & .394 & .212 & .389 & -.406 & .042 & -.188 & .448 & 10 \\
\hline Conductivity at time of RTH sampling & .423 & .755 & .388 & .202 & .202 & -.031 & .143 & 10 \\
\hline $\begin{array}{l}\text { Dissolved oxygen at time of RTH } \\
\text { sampling }\end{array}$ & -.079 & -.370 & -.030 & .491 & .006 & .430 & .178 & 10 \\
\hline Temperature at time of RTH sampling & -.037 & .287 & -.080 & -.506 & -.165 & -.543 & -.198 & 10 \\
\hline
\end{tabular}


Unlike the RTH and QMH samples, interpretation of the DTH sample ordination is not as straight forward. The main axis (axis 1) of the DTH ordination was significantly correlated with just two variables — standard error of bank angle (negative correlation) and mean water depth where the DTH sample was collected (positive correlation). These two factors may be related to bank erosion and deposition of fine sediments, which may determine the kinds of organisms that can exist in DTH (pool-like) habitats. The second axis of the DTH ordinations was related to the concentrations of dissolved oxygen and nickel, mean bank height, standard error in bank height, and standard error in bank width. Dissolved oxygen concentrations and contamination by metals can both be very important in controlling the distribution of organisms. It is, however, questionable whether the methods used to determine dissolved oxygen and concentrations of nickel are particularly relevant to the DTH sample collections. Likewise, the role of bank height and variability in the distribution of invertebrates is not obvious. The most conservative interpretation of the DTH ordination is that this study did not measure the suite of characteristics that would be most useful in interpreting the distribution of invertebrates associated with depositional habitats. Variables, such as concentrations of oxygen in bed-sediment pore water, metals in sediment, organic matter content of sediment, and sediment particle-size composition, would be valuable in further studies.

Indirect gradient analysis is a sophisticated tool for analyzing the distribution of invertebrates and gaining an understanding of the factors that control these distributions. In this study, indirect gradient analysis was useful for underscoring the strong influence that drainage-basin size has on the distribution of invertebrates. This analysis supports the contention that, biologically, these sites represent three groups - small, intermittent streams; midsize streams; and rivers. The dominant factors accounting for the distribution of benthic invertebrates are associated with natural factors (that is, basin size) rather than land use.

\section{TRANSPORT OF SUSPENDED SEDIMENT, NUTRIENTS, AND TOTAL ORGANIC CARBON}

Annual loads of suspended sediment, nitrogen, phosphorus, total organic carbon, and total dissolved solids were estimated for the years during 1989-98 when continuous streamflow data were available. Estimates of annual loads were normalized by drainage-basin size and were used as a basis of comparison among basins.

Watershed protection measures and pollution limits under provisions of the Clean Water Act (U.S. Environmental Protection Agency, 1999) are based in part on consideration of constituent load.

Constituent load was calculated from instantaneous streamflow recorded at 0.25 - to 1 -hour intervals at the Treyburn development study sites and from predicted instantaneous load. Predicted instantaneous load was derived from analytical results of monthly and storm-runoff samples and instantaneous streamflow by using the following equation:

$$
Q_{1}=a Q C,
$$

where

$Q_{1}$ is load, expressed in units of weight (mass) per time;

$a$ is a conversion factor;

$Q$ is instantaneous streamflow, expressed in cubic feet per second; and

$C$ is constituent concentration, expressed in micrograms per liter or milligrams per liter, depending on the constituent.

For each of the study sites, a regression model was developed from calculated load and streamflow. When a sample concentration was censored at the laboratory reporting level, the concentration was assumed to be equal to the reporting level. This was a reasonable assumption because concentrations of the constituent of interest at these sites increased with increasing streamflow. Concentrations below the reporting level occurred during periods of lowest streamflow, so periods of low flow did not contribute significantly to the annual load. When significant streamflow record was missing and published estimates of daily mean flow were available, load was calculated by applying the regression model to the daily mean streamflow.

In developing the regression models, the effects of discharge variation and temporal and seasonal trends on constituent load were tested. Explanatory variables tested in each regression model were streamflow, time, and the sine and cosine of time. The form of the regression equation is

$$
\begin{aligned}
\ln (Y)=\beta_{0}+ & \beta_{1}(\ln Q)+\beta_{2}(t)+\beta_{3} \sin (2 \pi t) \\
& +\beta_{4} \cos (2 \pi t),
\end{aligned}
$$


where

$Y$ is the predicted constituent load;

$\ln Q$ is the natural logarithm of streamflow;

$\beta_{0}$ is the intercept and $\beta_{1,2,3,4}$ are regression coefficients; and

$t$ is time expressed in years since January 1, 1988.

The best-fit regression model was selected for each constituent and each site. The selection was made to retain coefficients significant at $p<0.05$ to minimize Mallow's criterion (Snedecor and Cochran, 1980, p. 359) and to minimize the number of explanatory variables in the model.
The bias introduced when results are retransformed from the logarithmic space to base-10 space was corrected by applying a bias correction factor (BCF). Duan's smearing estimator - the mean of the antilog of the regression residuals from the log-transformed regression model - was selected for bias correction (Gilroy and others, 1990). Bias correction factors ranged from 1.02 to 1.89 ; a BCF of 1.0 is equivalent to no correction for bias (Koltun and others, 1994). Model output was load in kilograms per day (table 14). Load in kilograms per day was converted to tons per day for comparison with estimates of load from other studies. Annual load estimates were normalized, based on drainage area, to determine annual constituent yield in tons per year per square mile.

Table 14. Regression models used to estimate nutrient, suspended-sediment, and total organic carbon loads at five sites in the Treyburn development study area

\begin{tabular}{|c|c|}
\hline Constituent & Regression model to estimate load, in kilograms per day \\
\hline \multicolumn{2}{|r|}{ Flat River tributary (site 1T) } \\
\hline Total nitrogen & $1.065(\exp (0.28+1.078(1 \mathrm{nQ})-0.044(\mathrm{t})))$ \\
\hline Total ammonia plus organic nitrogen & $1.069(\exp (0.039+1.157(1 \mathrm{nQ})-0.227(\sin (\mathrm{t}))-0.124(\cos (\mathrm{t}))-0.049(\mathrm{t})))$ \\
\hline Total ammonia nitrogen & $1.247(\exp (-2.806+1.056(1 \mathrm{nQ})-0.081(\sin (\mathrm{t}))-0.395(\cos (\mathrm{t}))))$ \\
\hline Total nitrite plus nitrate nitrogen & $1.188(\exp (-1.441+0.974(1 \mathrm{nQ})))$ \\
\hline Total phosphorus & $1.161(\exp (-2.727+1.293(1 \mathrm{nQ})-0.424(\sin (\mathrm{t}))-0.284(\cos (\mathrm{t}))-0.003(\mathrm{t})))$ \\
\hline Orthophosphorus & $1.282(\exp (-3.141+1.057(1 \mathrm{nQ})-0.169(\sin (\mathrm{t}))-0.119(\cos (\mathrm{t}))-0.034(\mathrm{t})))$ \\
\hline Suspended sediment & $1.889(\exp (4.199+1.562(\operatorname{lnQ})-0.650(\sin (t))-0.457(\cos (t))))$ \\
\hline Total organic carbon & $1.091(\exp (2.491+1.404(1 \mathrm{nQ})-0.472(\sin (\mathrm{t}))-0.309(\cos (\mathrm{t}))))$ \\
\hline Total dissolved solids & Insufficient data. \\
\hline \multicolumn{2}{|r|}{ Flat River (site 5T) } \\
\hline Total nitrogen & $1.044(\exp (0.157+1.136(1 \mathrm{nQ})-0.040(\mathrm{t})))$ \\
\hline Total ammonia plus organic nitrogen & $1.078(\exp (-0.626+1.207(1 \mathrm{nQ})-0.277(\sin (\mathrm{t}))-0.188(\cos (\mathrm{t}))-0.047(\mathrm{t})))$ \\
\hline Total ammonia nitrogen & $1.269(\exp (-3.164+1.150(1 \mathrm{nQ})-0.200(\sin (\mathrm{t}))-0.498(\cos (\mathrm{t}))))$ \\
\hline Total nitrite plus nitrate nitrogen & $1.129(\exp (-1.201+1.141(1 \mathrm{nQ})))$ \\
\hline Total phosphorus & $1.145(\exp (-3.486+1.356(1 \mathrm{nQ})-0.397(\sin (\mathrm{t}))-0.276(\cos (\mathrm{t}))-0.051(\mathrm{t})))$ \\
\hline Orthophosphorus & $1.101(\exp (-3.574+1.204(1 \mathrm{nQ})-0.345(\sin (\mathrm{t}))-0.286(\cos (\mathrm{t}))-0.062(\mathrm{t})))$ \\
\hline Suspended sediment & $1.335(\exp (1.220+2.666(1 \mathrm{nQ})-0.770(\sin (\mathrm{t}))-0.528(\cos (\mathrm{t}))))$ \\
\hline Total organic carbon & $1.032(\exp (1.990+1.203(1 \mathrm{nQ})-0.332(\sin (\mathrm{t}))-0.200(\cos (\mathrm{t}))))$ \\
\hline Total dissolved solids & Insufficient data. \\
\hline \multicolumn{2}{|r|}{ Little River (site 10TA) } \\
\hline Total nitrogen & $1.024(\exp (0.403+1.028(1 \mathrm{nQ})))$ \\
\hline Total ammonia plus organic nitrogen & $1.025(\exp (-0.98+1.068(1 \mathrm{nQ})-0.278(\sin (\mathrm{t}))-0.062(\cos (\mathrm{t}))))$ \\
\hline Total ammonia nitrogen & $1.238(\exp (-2.645+1.090(1 \mathrm{nQ})-0.489(\sin (\mathrm{t}))+0.100(\cos (\mathrm{t}))))$ \\
\hline Total nitrite plus nitrate nitrogen & $1.105(\exp (-0.681+0.958(1 \mathrm{nQ})+0.467(\sin (\mathrm{t}))+0.408(\cos (\mathrm{t}))))$ \\
\hline Total phosphorus & $1.308(\exp (-3.072+1.166(1 \mathrm{nQ})-0.580(\sin (\mathrm{t}))+0.026(\cos (\mathrm{t}))))$ \\
\hline Orthophosphorus & $1.376(\exp (-3.482+1.057(1 \mathrm{nQ})-0.538(\sin (\mathrm{t}))+0.100(\cos (\mathrm{t}))))$ \\
\hline Suspended sediment & $1.198(\exp (3.085+1.151(1 \mathrm{nQ})-0.548(\sin (\mathrm{t}))-0.033(\cos (\mathrm{t}))))$ \\
\hline Total organic carbon & Insufficient data. \\
\hline Total dissolved solids & Insufficient data. \\
\hline
\end{tabular}


Table 14. Regression models used to estimate nutrient, suspended-sediment, and total organic carbon loads at five sites in the Treyburn development study area-Continued

\begin{tabular}{ll}
\hline \multicolumn{1}{c}{ Constituent } & \multicolumn{1}{c}{ Regression model to estimate load, in kilograms per day } \\
\hline Total nitrogen & \multicolumn{1}{c}{ Mountain Creek (site 6T) } \\
Total ammonia plus organic nitrogen & $1.044(\exp (0.783+1.152(1 \mathrm{nQ})-0.070(\sin (\mathrm{t}))-0.183(\cos (\mathrm{t}))-0.052(\mathrm{t})))$ \\
Total ammonia nitrogen & $1.401(\exp (-2.891+1.220(1 \mathrm{nQ})-0.193(\sin (\mathrm{t}))-0.388(\cos (\mathrm{t}))))$ \\
Total nitrite plus nitrate nitrogen & $1.126(\exp (0.224+1.062(1 \mathrm{nQ})+0.179(\sin (\mathrm{t}))-0.163(\cos (\mathrm{t}))-0.088(\mathrm{t})))$ \\
Total phosphorus & $1.314(\exp (-2.896+1.424(1 \mathrm{nQ})-0.559(\sin (\mathrm{t}))-0.360(\cos (\mathrm{t}))))$ \\
Orthophosphorus & $1.188(\exp (-3.067+1.273(1 \mathrm{nQ})-0.460(\sin (\mathrm{t}))-0.346(\cos (\mathrm{t}))-0.047(\mathrm{t})))$ \\
Suspended sediment & $1.768(\exp (2.240+1.658(1 \mathrm{nQ})-0.510(\sin (\mathrm{t}))-0.516(\cos (\mathrm{t}))+0.079(\mathrm{t})))$ \\
Total organic carbon & $1.079(\exp (2.430+1.149(1 \mathrm{nQ})-0.318(\sin (\mathrm{t}))-0.319(\cos (\mathrm{t}))))$ \\
Total dissolved solids & Insufficient data. \\
\hline & Little River tributary $(\operatorname{site} 8 \mathrm{~T})$ \\
\hline Total nitrogen & $1.083(\exp (0.439+1.264(1 \mathrm{nQ})-0.312(\sin (\mathrm{t}))-0.472(\cos (\mathrm{t}))))$ \\
Total ammonia plus organic nitrogen & $1.068(\exp (0.163+1.272(1 \mathrm{nQ})-0.369(\sin (\mathrm{t}))-0.505(\cos (\mathrm{t}))))$ \\
Total ammonia nitrogen & $1.318(\exp (-2.435+1.088(1 \mathrm{nQ})-0.404(\sin (\mathrm{t}))-0.605(\cos (\mathrm{t}))))$ \\
Total nitrite plus nitrate nitrogen & $1.231(\exp (-1.074+1.246(1 \mathrm{nQ})-0.176(\sin (\mathrm{t}))-0.361(\cos (\mathrm{t}))))$ \\
Total phosphorus & $1.268(\exp (-1.914+1.556(1 \mathrm{nQ})-0.674(\sin (\mathrm{t}))-0.697(\cos (\mathrm{t}))))$ \\
Orthophosphorus & $1.255(\exp (-2.385+1.563(1 \mathrm{nQ})-0.594(\sin (\mathrm{t}))-0.553(\cos (\mathrm{t}))))$ \\
Suspended sediment & $1.350(\exp (4.111+1.398(1 \mathrm{nQ})))$ \\
Total organic carbon & Insufficient data. \\
Total dissolved solids & Insufficient data. \\
\hline
\end{tabular}

\section{Suspended Sediment}

Annual suspended-sediment loads were calculated from the selected regression models for water years 1989-98 (table 15). The regression models for all but Little River tributary included explanatory variables for seasonal effects in addition to discharge (table 14). The regression model for Mountain Creek included an explanatory variable for temporal variation in suspended sediment.

The median annual suspended-sediment loads at the Treyburn development study sites ranged from 135 to

Table 15. Annual and median suspended-sediment yield and load for water years 1989-98 at Treyburn development study area sites $[-$, no data $]$

\begin{tabular}{|c|c|c|c|c|c|c|c|c|c|c|}
\hline \multirow[b]{2}{*}{ Year } & \multicolumn{5}{|c|}{ Annual suspended-sed iment yield, in tons per square mile } & \multicolumn{5}{|c|}{ Annual suspended-sediment load, in tons } \\
\hline & $\begin{array}{c}\text { Flat River } \\
\text { tributary } \\
\text { (site 1T) }\end{array}$ & $\begin{array}{c}\text { Mountain } \\
\text { Creek } \\
\text { (site 6T) }\end{array}$ & $\begin{array}{l}\text { Little River } \\
\text { (site 10TA) }\end{array}$ & $\begin{array}{c}\text { Flat River } \\
\text { (site } 5 T \text { ) }\end{array}$ & $\begin{array}{c}\text { Little River } \\
\text { tributary } \\
\text { (site 8T) }\end{array}$ & $\begin{array}{c}\text { Flat River } \\
\text { tributary } \\
\text { (site 1T) }\end{array}$ & $\begin{array}{c}\text { Mountain } \\
\text { Creek } \\
\text { (site 6T) }\end{array}$ & $\begin{array}{l}\text { Little River } \\
\text { (site 10TA) }\end{array}$ & $\begin{array}{c}\text { Flat River } \\
\text { (site } 5 T \text { ) }\end{array}$ & $\begin{array}{c}\text { Little River } \\
\text { tributary } \\
\text { (site } 8 \mathrm{~T} \text { ) }\end{array}$ \\
\hline 1989 & 172 & - & - & 207 & - & 196 & - & - & 30,900 & - \\
\hline 1990 & 144 & - & - & 80 & - & - & - & - & 11,900 & - \\
\hline 1991 & - & - & - & 93 & - & - & - & - & 13,800 & - \\
\hline 1992 & - & - & - & - & - & - & - & - & - & - \\
\hline 1993 & - & - & - & - & - & - & - & - & - & - \\
\hline 1994 & - & - & - & 95 & - & - & - & - & 14,200 & - \\
\hline 1995 & 404 & 405 & - & 161 & 116 & 461 & 3,240 & - & 24,000 & 100 \\
\hline 1996 & 4,670 & 12,900 & 47 & 2,640 & 625 & 5,320 & 104,000 & 4,688 & 392,600 & 538 \\
\hline 1997 & 90 & 87 & 17 & 90 & 65 & 103 & 699 & 1,688 & 13,500 & 56 \\
\hline 1998 & 246 & 438 & 32 & 281 & 198 & 280 & 3,510 & 3,180 & 41,900 & 170 \\
\hline Median & 209 & 422 & 32 & 128 & 157 & 238 & 3,370 & 3,180 & 19,100 & 135 \\
\hline
\end{tabular}


19,100 tons (table 15). Major runoff can have a significant effect on the total annual load of suspended sediment. The extreme flooding caused by Hurricane Fran in early September 1996 resulted in an estimated 1-day suspended-sediment load at Flat River at Bahama of 211,000 tons (fig. 17). That amount is about 53 percent of the total load of suspended sediment for 1996 and exceeded the median annual load by 20 times. The annual load in the 1996 water year exceeded the median annual load by more than an order of magnitude at Mountain Creek and Flat River tributary (table 15). The increased suspended sediment in Little River in 1996 was not as dramatic because of reservoir trapping.

Annual loads were normalized, based on drainage area, to determine annual suspended-sediment yield (fig. 18). Although Flat River contributes the greatest load of suspended sediment, it has by far the largest drainage area. In terms of yield in tons per square mile of drainage area, the annual load from Flat River was the second lowest. The maximum annual suspended-sediment yield was at Mountain Creek (422 tons per square mile [tons $\left./ \mathrm{mi}^{2}\right]$ ), and the minimum annual yield was at Little River (32 tons $/ \mathrm{mi}^{2}$ ). The annual yield at Little River tributary was nearly that at Flat River tributary. The Little River Reservoir provides for the settling of suspended sediments, thus reducing sediment load at the Little River site.

Annual suspended-sediment yields were compared to annual yields from basins of similar size with various land covers in the upper Neuse River Basin and the
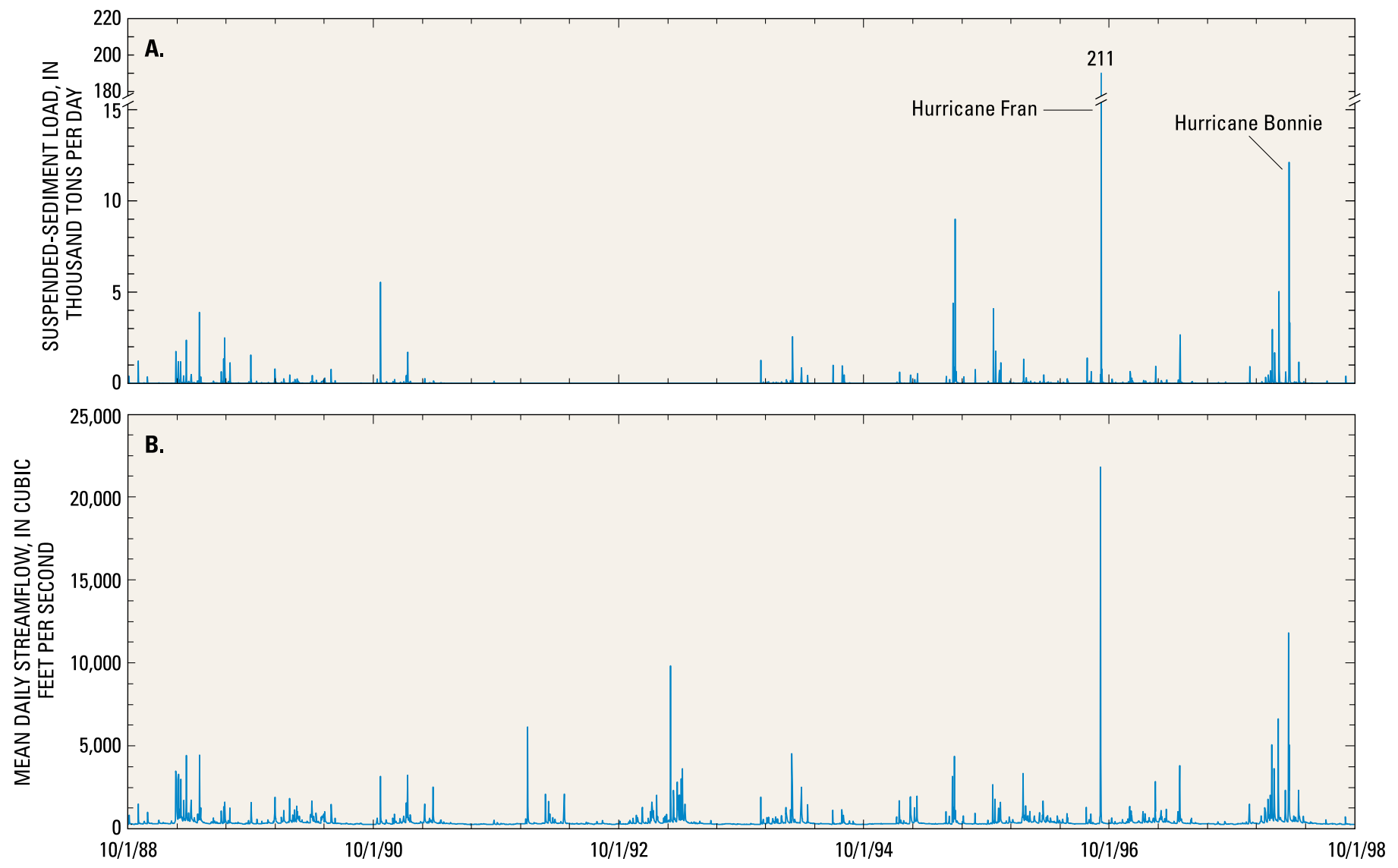

Figure 17. Hydrographs of (A) suspended sediment and (B) streamflow at Flat River at Bahama for water years 1989-98. 


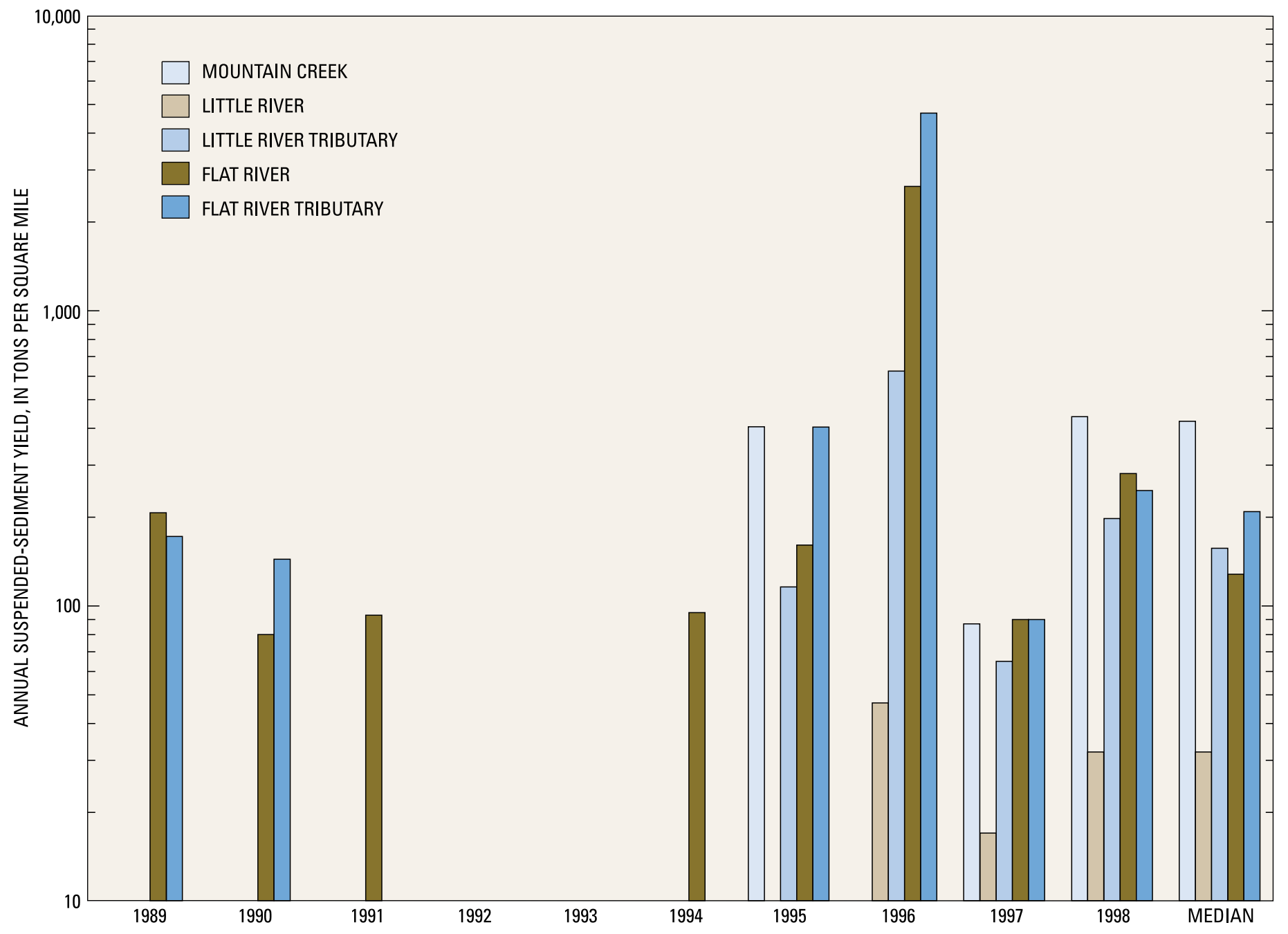

Figure 18. Annual and median suspended-sediment yields at the Treyburn development study area sites for water years 1989-98.

Charlotte metropolitan area (table 16). The suspendedsediment yield for Mountain Creek (mixed forest and agriculture) was similar to the yield reported for a mixed land cover site in Charlotte. The annual suspendedsediment yield for Flat River tributary was high compared to other forested basins in the Piedmont (about 45 tons $/ \mathrm{mi}^{2}$ ), but was comparable to annual yields reported for mixed land-use basins near the study area (that is, Flat and Little Rivers upstream from the reservoir near Orange Factory) and agricultural basins in the Piedmont (Simmons, 1993). The smallest yield was at Little River (site 10TA) because of reservoir trapping.

\section{Nutrients}

Nutrient concentrations, especially nitrogen and phosphorus, are key factors in the overenrichment of reservoirs. In August 1998, the State of North Carolina established guidelines limiting the discharge of nitrogen to the Neuse River Basin for the purpose of reducing nitrogen discharges by 30 percent in 5 years (North Carolina Department of Environment and Natural Resources, 1999). The USEPA also recently established guidelines for nutrients to lakes, reservoirs, and streams (U.S. Environmental Protection Agency, 2000).

Concentrations of total organic nitrogen, ammonia, nitrite 


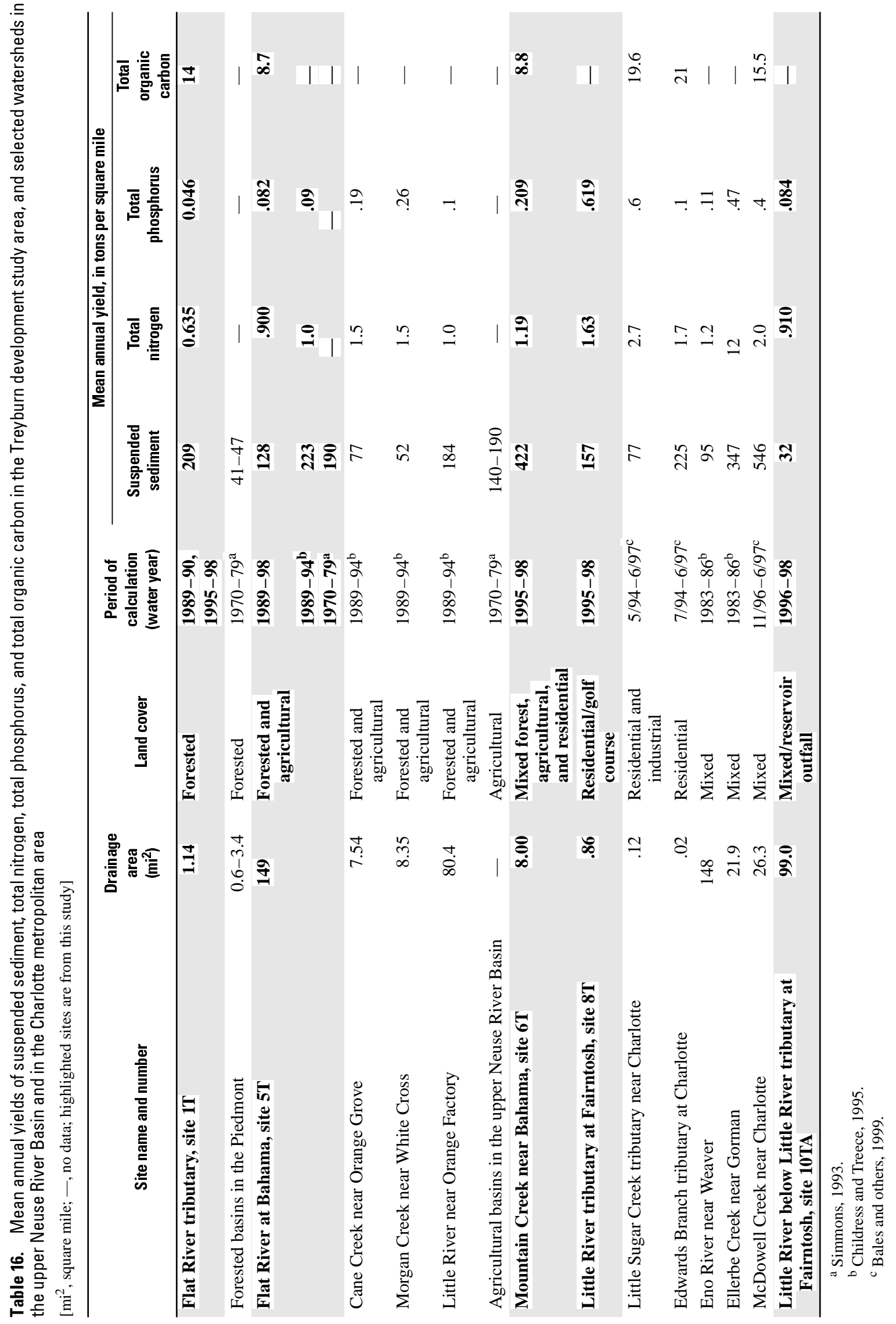


plus nitrate, phosphorus, and orthophosphorus were sampled monthly during the study period and during selected runoff events. These data were the basis of regression models developed for nutrient loads (table 14).

Discharge was a significant explanatory factor for all nitrogen species regression models at all sites. Seasonality also was an explanatory variable in regression models for total nitrogen, ammonia plus organic nitrogen, and ammonia nitrogen loads at certain sites (table 14). For all sites except the Flat River and Flat River tributary sites, seasonal effects also were significant for nitriteplus-nitrate loads.
Annual median total nitrogen loads ranged from 0.724 to 134 tons at Flat River tributary and Flat River, respectively (table 17). When normalized by drainagebasin size, the median annual total nitrogen yield ranged from 0.635 ton $/ \mathrm{mi}^{2}$ (Flat River tributary) to 1.63 tons $/ \mathrm{mi}^{2}$ (Little River tributary; fig. 19). Mountain Creek had the second highest annual yield-1.19 tons $/ \mathrm{mi}^{2}$. Flat River and Little River each had annual yields near 0.9 ton $/ \mathrm{mi}^{2}$, indicating a minimal trapping effect for nitrogen in the Little River Reservoir. This is further supported by the annual total nitrogen yield for the Little River near Orange Factory upstream from the reservoir (1.0 ton $/ \mathrm{mi}^{2}$; table 16).

Table 17. Annual and median total nitrogen yield and load for water years 1989-98 at Treyburn development study area sites $[-$, no data $]$

\begin{tabular}{|c|c|c|c|c|c|c|c|c|c|c|}
\hline \multirow[b]{2}{*}{ Year } & \multicolumn{5}{|c|}{ Annual total nitrogen yield, in tons per square mile } & \multicolumn{5}{|c|}{ Annual total nitrogen load, in tons } \\
\hline & $\begin{array}{c}\text { Flat River } \\
\text { tributary } \\
\text { (site 1T) }\end{array}$ & $\begin{array}{c}\text { Mountain } \\
\text { Creek } \\
\text { (site 6T) }\end{array}$ & $\begin{array}{l}\text { Little River } \\
\text { (site 10TA) }\end{array}$ & $\begin{array}{c}\text { Flat River } \\
\text { (site 5T) }\end{array}$ & $\begin{array}{c}\text { Little River } \\
\text { tributary } \\
\text { (site 8T) }\end{array}$ & $\begin{array}{c}\text { Flat River } \\
\text { tributary } \\
\text { (site 1T) }\end{array}$ & $\begin{array}{c}\text { Mountain } \\
\text { Creek } \\
\text { (site 6T) }\end{array}$ & $\begin{array}{l}\text { Little River } \\
\text { (site 10TA) }\end{array}$ & $\begin{array}{c}\text { Flat River } \\
\text { (site } 5 T \text { ) }\end{array}$ & $\begin{array}{c}\text { Little River } \\
\text { tributary } \\
\text { (site 8T) }\end{array}$ \\
\hline 1989 & 0.694 & - & - & 1.63 & - & 0.791 & - & - & 242 & - \\
\hline 1990 & .763 & - & - & 1.02 & - & .870 & - & - & 152 & - \\
\hline 1991 & - & - & - & .725 & - & - & - & - & 108 & - \\
\hline 1992 & - & - & - & - & - & - & - & - & - & - \\
\hline 1993 & - & - & - & - & - & - & - & - & - & - \\
\hline 1994 & - & - & - & .751 & - & - & - & - & 112 & - \\
\hline 1995 & .391 & 0.939 & - & .623 & 1.69 & .445 & 7.51 & - & 93.0 & 1.46 \\
\hline 1996 & 1.12 & 2.06 & 0.910 & 1.93 & 8.95 & 1.28 & 16.5 & 90.0 & 287 & 7.69 \\
\hline 1997 & .364 & .745 & .583 & .779 & .819 & .414 & 5.96 & 57.7 & 116 & .704 \\
\hline 1998 & .576 & 1.44 & 1.11 & 1.52 & 1.58 & .657 & 11.5 & 109 & 226 & 1.36 \\
\hline Median & .635 & 1.19 & .910 & .900 & 1.63 & .724 & 9.50 & 90.0 & 134 & 1.40 \\
\hline
\end{tabular}

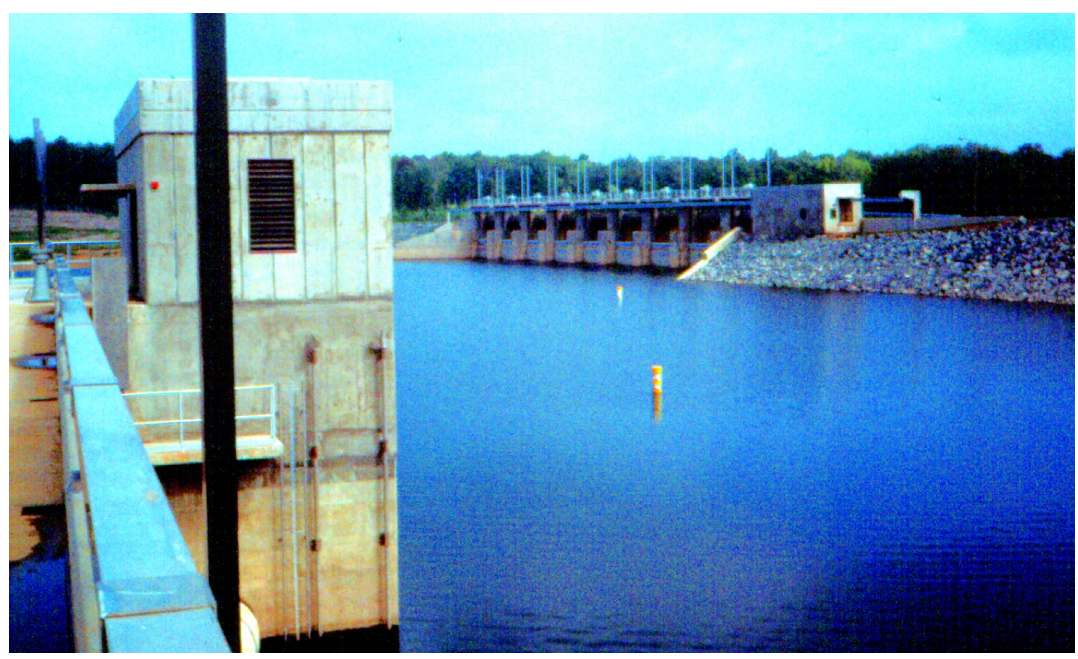

Little River Reservoir and Dam. 


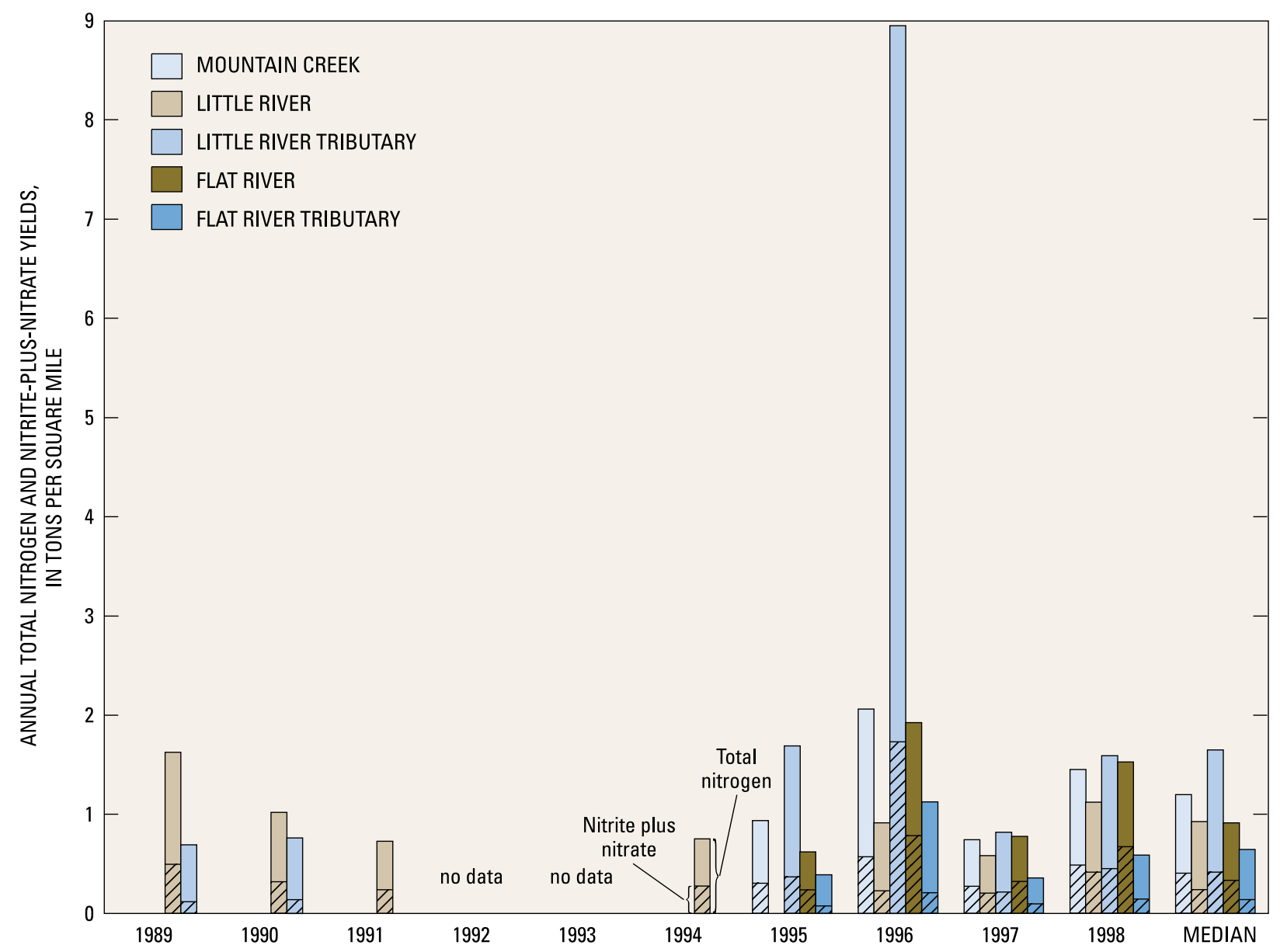

Figure 19. Annual and median total nitrogen and nitrite-plus-nitrate yields at the Treyburn development study area sites for water years $1989-98$.

Median annual nitrite-plus-nitrate yields ranged from $0.126 \mathrm{ton} / \mathrm{mi}^{2}$ at the Flat River tributary to $0.408 \mathrm{ton} / \mathrm{mi}^{2}$ at the Little River tributary (table 18; fig. 19). Nitrite plus nitrate accounted for less than 20 percent of the annual total-nitrogen yield at the Flat River tributary but accounted for more than 33 percent of the annual yield at Mountain Creek and Flat River. Ammonia plus organic nitrogen accounted for the balance of the annual nitrogen yield, ranging from $0.497 \mathrm{ton} / \mathrm{mi}^{2}$ at the Flat River tributary to 1.24 tons $/ \mathrm{mi}^{2}$ at the Little River tributary (table 18).

Childress and Treece (1996) reported that the annual total-nitrogen yield for the forested Flat River tributary (site 1T) was less than half that for mixed forested and agricultural watersheds in the Piedmont. The median annual yield of $1.63 \mathrm{tons} / \mathrm{mi}^{2}$ for the Little River tributary (site 8T; table 17) was similar to that reported for a small residential land-use watershed in the Charlotte area (1.7 tons $/ \mathrm{mi}^{2}$; table 16) and larger forested and agricultural land-use watersheds in the Triangle area
(1.5 tons $/ \mathrm{mi}^{2}$; table 16$)$. The annual total-nitrogen yield determined for Flat River was the same as that determined in an earlier study for a similar time period (1.0 ton $/ \mathrm{mi}^{2}$; table 16).

Streamflow and seasonality were significant explanatory variables in regression models for total phosphorus and orthophosphate at all sites (table 14). Median annual total phosphorus loads ranged from 0.052 ton at Flat River tributary to 12.2 tons at Flat River (table 19). The load at Little River tributary was an order of magnitude greater than that at Flat River tributary even though the drainage area for Flat River tributary is slightly larger. This likely is a result of the residential and golf course land cover in the Little River tributary basin.

Median annual total phosphorus yields ranged from 0.046 to 0.619 ton $/ \mathrm{mi}^{2}$ (table 19; fig. 20). The greatest annual yield was at Little River tributary and was almost three times greater than the next highest annual yield $\left(0.209 \mathrm{ton} / \mathrm{mi}^{2}\right)$ at Mountain Creek. Annual total phosphorus yields exceeding $0.3 \mathrm{ton} / \mathrm{mi}^{2}$ were reported 
Table 18. Annual and median total nitrite-plus-nitrate nitrogen yield, and total ammonia plus organic nitrogen yield for water years 1989-98 at Treyburn development study area sites

\begin{tabular}{|c|c|c|c|c|c|c|c|c|c|c|}
\hline \multirow[b]{2}{*}{ Year } & \multicolumn{5}{|c|}{$\begin{array}{l}\text { Annual total nitrite-plus-nitrate nitrogen yield, } \\
\text { in tons per square mile }\end{array}$} & \multicolumn{5}{|c|}{$\begin{array}{l}\text { Annual total ammonia plus organic nitrogen yield, } \\
\text { in tons per square mile }\end{array}$} \\
\hline & $\begin{array}{c}\text { Flat River } \\
\text { tributary } \\
\text { (site 1T) }\end{array}$ & $\begin{array}{c}\text { Mountain } \\
\text { Creek } \\
\text { (site 6T) }\end{array}$ & $\begin{array}{l}\text { Little River } \\
\text { (site 10TA) }\end{array}$ & $\begin{array}{c}\text { Flat River } \\
\text { (site 5T) }\end{array}$ & $\begin{array}{c}\text { Little River } \\
\text { tributary } \\
\text { (site 8T) }\end{array}$ & $\begin{array}{c}\text { Flat River } \\
\text { tributary } \\
\text { (site 1T) }\end{array}$ & $\begin{array}{c}\text { Mountain } \\
\text { Creek } \\
\text { (site 6T) }\end{array}$ & $\begin{array}{l}\text { Little River } \\
\text { (site 10TA) }\end{array}$ & $\begin{array}{c}\text { Flat River } \\
\text { (site } 5 T \text { ) }\end{array}$ & $\begin{array}{r}\text { Little River } \\
\text { tributary } \\
\text { (site 8T) }\end{array}$ \\
\hline 1989 & 0.119 & - & - & 0.492 & - & 0.556 & - & - & 1.07 & - \\
\hline 1990 & .142 & - & - & .318 & - & .603 & - & - & .625 & - \\
\hline 1991 & - & - & - & .235 & - & - & - & - & .458 & - \\
\hline 1992 & - & - & - & - & - & - & - & - & - & - \\
\hline 1993 & - & - & - & - & - & - & - & - & - & - \\
\hline 1994 & - & - & - & .276 & - & - & - & - & .454 & - \\
\hline 1995 & .081 & 0.310 & - & .240 & 0.376 & .365 & 0.679 & - & .437 & 1.33 \\
\hline 1996 & .208 & .572 & 0.228 & .782 & 1.73 & 1.48 & 1.80 & 0.793 & 1.85 & 7.45 \\
\hline 1997 & .096 & .275 & .204 & .322 & .213 & .272 & .492 & .395 & .458 & .606 \\
\hline 1998 & .133 & .476 & .406 & .658 & .441 & .439 & 1.03 & .720 & .878 & 1.14 \\
\hline Median & .126 & .393 & .228 & .320 & .408 & .497 & .855 & .720 & .542 & 1.24 \\
\hline
\end{tabular}

Table 19. Annual and median total phosphorus yield and load for water years 1989-98 at Treyburn development study area sites $[-$, no data $]$

\begin{tabular}{|c|c|c|c|c|c|c|c|c|c|c|}
\hline \multirow[b]{2}{*}{ Year } & \multicolumn{5}{|c|}{ Annual total phosphorus yield, in tons per square mile } & \multicolumn{5}{|c|}{ Annual total phosphorus load, in tons } \\
\hline & $\begin{array}{c}\text { Flat River } \\
\text { tributary } \\
\text { (site 1T) }\end{array}$ & $\begin{array}{l}\text { Mountain } \\
\text { Creek } \\
\text { (site 6T) }\end{array}$ & $\begin{array}{l}\text { Little River } \\
\text { (site 10TA) }\end{array}$ & $\begin{array}{c}\text { Flat River } \\
\text { (site } 5 T \text { ) }\end{array}$ & $\begin{array}{c}\text { Little River } \\
\text { tributary } \\
\text { (site 8T) }\end{array}$ & $\begin{array}{c}\text { Flat River } \\
\text { tributary } \\
\text { (site 1T) }\end{array}$ & $\begin{array}{c}\text { Mountain } \\
\text { Creek } \\
\text { (site 6T) }\end{array}$ & $\begin{array}{l}\text { Little River } \\
\text { (site 10TA) }\end{array}$ & $\begin{array}{c}\text { Flat River } \\
\text { (site 5T) }\end{array}$ & $\begin{array}{c}\text { Little River } \\
\text { tributary } \\
\text { (site 8T) }\end{array}$ \\
\hline 1989 & 0.051 & - & - & 0.175 & - & 0.058 & - & - & 26.1 & - \\
\hline 1990 & .053 & - & - & .089 & - & .060 & - & - & 13.2 & - \\
\hline 1991 & - & - & - & .071 & - & - & - & - & 10.5 & - \\
\hline 1992 & - & - & - & - & - & - & - & - & - & - \\
\hline 1993 & - & - & - & - & - & - & - & - & - & - \\
\hline 1994 & - & - & - & .069 & - & - & - & - & 10.3 & - \\
\hline 1995 & .040 & 0.201 & - & .075 & 0.855 & .046 & 1.61 & - & 11.1 & 0.735 \\
\hline 1996 & .040 & .658 & 0.125 & .464 & 8.96 & .046 & 5.26 & 12.361 & 69.1 & 7.70 \\
\hline 1997 & .032 & .080 & .044 & .065 & .150 & .036 & .640 & 4.347 & 9.67 & .129 \\
\hline 1998 & .062 & .218 & .084 & .146 & .382 & .071 & 1.74 & 8.320 & 21.7 & .328 \\
\hline Median & .046 & .209 & .084 & .082 & .619 & .052 & 1.67 & 8.320 & 12.2 & .532 \\
\hline
\end{tabular}

for mixed land-use sites receiving wastewater discharges in the Triangle area (Ellerbe Creek; Childress and Treece, 1996) and Charlotte (McDowell Creek; Bales and others, 1999), and for a small residential and industrial site in Charlotte (table 16; Bales and others, 1999). The annual yield at Mountain Creek closely matched those reported at two similar-size mixed forest and agricultural land-use sites in the Jordan Lake watershed -0.19 ton $/ \mathrm{mi}^{2}$ at Cane Creek and 0.26 ton $/ \mathrm{mi}^{2}$ at Morgan Creek (table 16).

Median annual total phosphorus yields for Little River (site 10TA) and Flat River (site 5T) for the study period were about the same - approximately $0.08 \mathrm{ton} / \mathrm{mi}^{2}$ and matched an earlier estimate for the Flat River (table 16). Suspended sediments settle in the Little River 


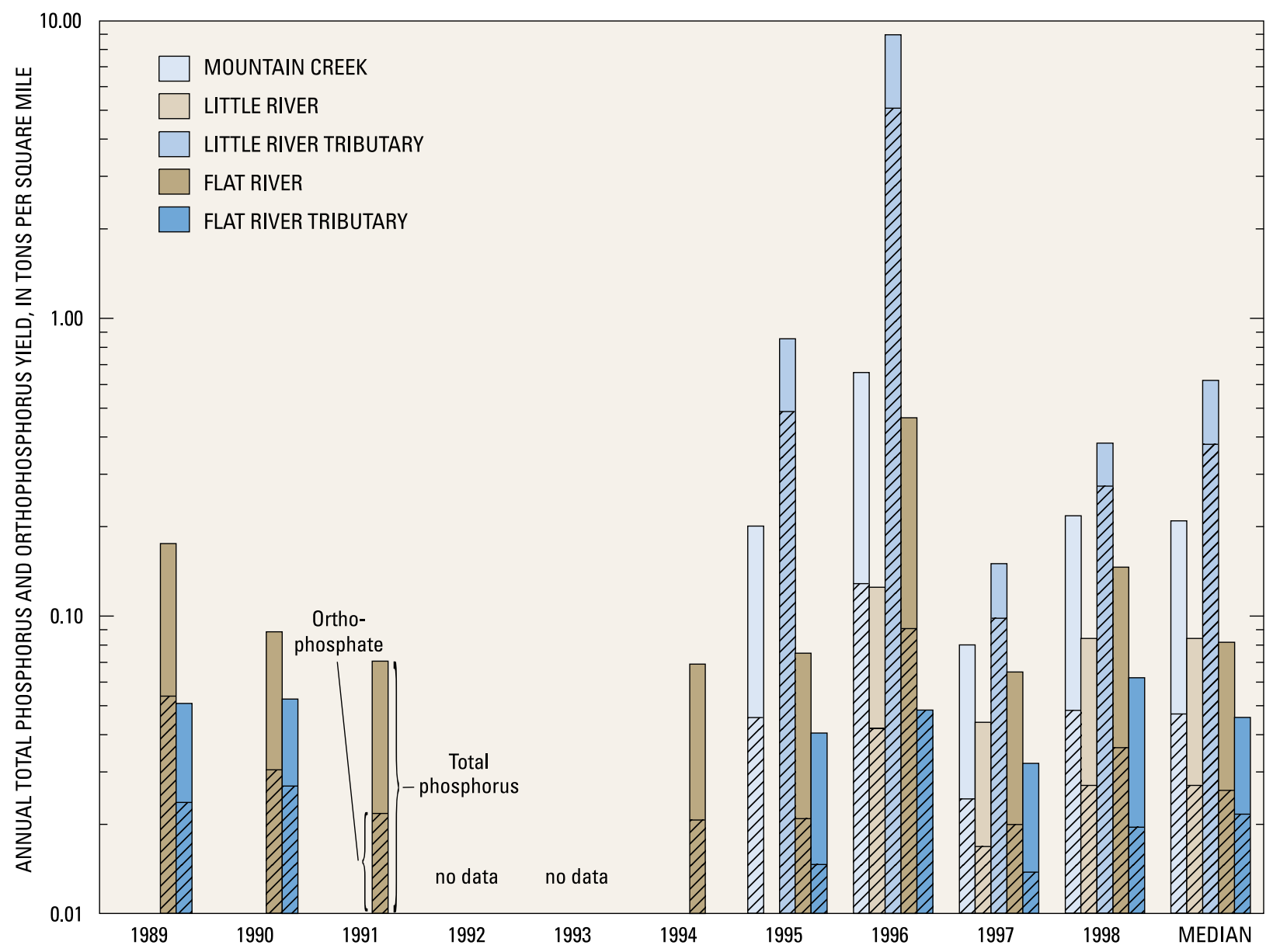

Figure 20. Annual and median total phosphorus and orthophosphate yields at the Treyburn development study area sites for water years 1989-98.

Reservoir, thereby reducing the total phosphorus load. The estimated annual yield for Little River was about 80 percent of that estimated by Childress and Treece (1996) for Little River near Orange Factory upstream from the Little River Reservoir based on the period 1989-94 (table 16).

Median annual orthophosphate yields ranged from 0.022 to 0.379 ton $/ \mathrm{mi}^{2}$ (table 20). The smallest annual yield was at Flat River tributary, but the yields were not much greater at Flat River, Little River, and Mountain Creek-less than 0.05 ton $/ \mathrm{mi}^{2}$. Orthophosphate accounted for more than half of the phosphorus yield for Little River tributary (fig. 20). Little River tributary watershed has a greater density of residential land use in addition to a golf course. Applications of fertilizers associated with these land uses may account for the relatively high load of orthophosphate in Little River tributary. 
Table 20. Annual and median total orthophosphate yield, and total organic carbon yield for water years 1989-98 at Treyburn development study area sites

$[-$, no data $]$

\begin{tabular}{|c|c|c|c|c|c|c|c|c|c|c|}
\hline \multirow[b]{2}{*}{ Year } & \multicolumn{5}{|c|}{ Annual total orthophosphate yield, in tons per square mile } & \multicolumn{5}{|c|}{ Annual total organic carbon yield, in tons per square mile } \\
\hline & $\begin{array}{c}\text { Flat River } \\
\text { tributary } \\
\text { (site 1T) }\end{array}$ & $\begin{array}{c}\text { Mountain } \\
\text { Creek } \\
\text { (site 6T) }\end{array}$ & $\begin{array}{l}\text { Little River } \\
\text { (site 10TA) }\end{array}$ & $\begin{array}{c}\text { Flat River } \\
\text { (site 5T) }\end{array}$ & $\begin{array}{c}\text { Little River } \\
\text { tributary } \\
\text { (site 8T) }\end{array}$ & $\begin{array}{c}\text { Flat River } \\
\text { tributary } \\
\text { (site 1T) }\end{array}$ & $\begin{array}{c}\text { Mountain } \\
\text { Creek } \\
\text { (site 6T) }\end{array}$ & $\begin{array}{l}\text { Little River } \\
\text { (site 10TA) }\end{array}$ & $\begin{array}{c}\text { Flat River } \\
\text { (site 5T) }\end{array}$ & $\begin{array}{c}\text { Little River } \\
\text { tributary } \\
\text { (site 8T) }\end{array}$ \\
\hline 1989 & 0.024 & - & - & 0.054 & - & 11.7 & - & - & 14.2 & - \\
\hline 1990 & .027 & - & - & .030 & - & 11.3 & 一 & - & 8.66 & - \\
\hline 1991 & - & - & - & .022 & - & - & - & - & 6.69 & - \\
\hline 1992 & - & - & - & - & - & - & - & - & - & - \\
\hline 1993 & - & - & - & - & - & - & - & - & - & - \\
\hline 1994 & - & - & - & .021 & - & - & - & - & 7.57 & - \\
\hline 1995 & .015 & 0.046 & - & .021 & 0.484 & 17.8 & 7.49 & - & 7.79 & - \\
\hline 1996 & .048 & .129 & 0.042 & .091 & 5.072 & 147 & 19.8 & - & 36.2 & - \\
\hline 1997 & .014 & .024 & .017 & .020 & .099 & 7.00 & 5.79 & - & 8.79 & - \\
\hline 1998 & .020 & .048 & .027 & .036 & .274 & 16.2 & 10.2 & - & 17.3 & - \\
\hline Median & .022 & .047 & .027 & .026 & .379 & 14 & 8.84 & - & 8.72 & - \\
\hline
\end{tabular}

\section{Total Organic Carbon}

Total organic carbon data, sufficient for loading estimations, were available for Flat River tributary, Mountain Creek, and Flat River. The annual total organic carbon yield at Flat River tributary was substantially more than the annual yield at Mountain Creek and Flat River (table 20). This may be due, in part, to the smaller size of the Flat River tributary drainage basin and to the forested setting that contributes organic material to the stream channel in the form of organic debris. However, total organic carbon yields of 15.5 to 21 tons $/ \mathrm{mi}^{2}$ were reported for mixed, residential, and residential/industrial land uses in the Charlotte metropolitan area (table 16; Bales and others, 1999).

\section{WATER-QUALITY TRENDS}

Results of seasonal trend tests for nitrogen and phosphorus species, total organic carbon, and suspended sediment are presented in this section (table 21). Data over a sufficiently long period to permit meaningful trend analysis were available only for Flat River (site 5T), Flat River tributary (site 1T), and Mountain Creek (site 6T). These sites were sampled from 1988 through 1998, except for sites 1T and 6T during water years 1992 and 1993, as part of the current and previous phases of the Treyburn study. All of these data were included in this analysis.

Temporal trends in selected water-quality constituents were tested by using the seasonal Kendall trend test (Hirsch and others, 1992). The seasonal Kendall test accounts for seasonal variations by comparing data within seasons and then aggregating the results. For this study, samples were collected approximately monthly so that each month was treated as a separate season. Streamflow variation also may be an important factor affecting concentration and adding noise to concentration trends. The effect of streamflow on concentration was taken into account by regressing instantaneous constituent load with instantaneous streamflow. When regression results indicated that streamflow significantly affected concentration, that is when the t-test of the regression coefficient was significant (alpha $=0.05$ ), the regression residuals were used for trend testing according to the method described by Helsel and Hirsch (1992).

Streamflow was a significant exogenous factor for total phosphorus, orthophosphate, total nitrogen, organic plus ammonia nitrogen, and suspended sediment at all sites.

The only significant trends (alpha $=0.05)$ were downward trends for total nitrogen, ammonia plus organic nitrogen, and organic nitrogen at Flat River tributary (table 21). The trend slope was small, approximately $0.019 \mathrm{mg} / \mathrm{L}$ per year of organic nitrogen at all sites, which is less than 9 percent of the median organic nitrogen concentration. No trend was observed for nitrite plus nitrate or for ammonia, indicating that the downward trend in total nitrogen was due only to organic nitrogen. Decreasing nitrogen trends were observed for the same time period at other nearby sites, including the Eno River near Weaver and Little River near Orange Factory (Childress and Bathala, 1997). 
Table 21. Results of seasonal trend analysis for nitrogen and phosphorus species, total organic carbon, and suspended sediment at Treyburn development study area sites

[-, no data; numbers in bold are significant at $p<0.05]$

\begin{tabular}{lcccccccc}
\hline & & \multicolumn{1}{c}{ Probability statistic } \\
\cline { 3 - 8 } \multicolumn{1}{c}{$\begin{array}{c}\text { Site name and number } \\
\text { (fig. 2) }\end{array}$} & $\begin{array}{c}\text { Years } \\
\text { of } \\
\text { record }\end{array}$ & $\begin{array}{c}\text { Total } \\
\text { phosphorus }\end{array}$ & $\begin{array}{c}\text { Ortho- } \\
\text { phosphate }\end{array}$ & $\begin{array}{c}\text { Total } \\
\text { nitrogen }\end{array}$ & $\begin{array}{c}\text { Nitrite } \\
\text { plus } \\
\text { nitrate }\end{array}$ & $\begin{array}{c}\text { Ammonia } \\
\text { plus organic } \\
\text { nitrogen }\end{array}$ & $\begin{array}{c}\text { Organic } \\
\text { nitrogen }\end{array}$ & $\begin{array}{c}\text { Suspended } \\
\text { sediment }\end{array}$ \\
\hline Mountain Creek (site 6T) & 11 & 0.193 & 0.232 & 0.085 & 0.072 & 0.733 & 0.702 & 0.900 \\
Flat River (site 5T) & 11 & .090 & .175 & .059 & .512 & .062 & .130 & .327 \\
Flat River tributary (site 1T) & 11 & .374 & - & $\mathbf{. 0 1 8}$ & .439 & $\mathbf{. 0 3 8}$ & $\mathbf{. 0 2 4}$ & .549 \\
\hline
\end{tabular}

\section{SUMMARY}

Treyburn is a 5,400-acre planned, mixed-use development located in the Falls Lake watershed in the upper Neuse River Basin of North Carolina. Development began in 1986 and consists of residential, industrial, and recreational facilities; the remaining land consists of forested and abandoned agricultural areas. Three watersupply reservoirs - Lake Michie to the north, Falls Lake to the southeast, and Little River Reservoir to the west - lie just outside the Treyburn boundaries. Treyburn was designed to minimize adverse effects of development on water quality. However, because of the size of the development and its proximity to the water-supply reservoirs, resource managers need to quantify the effects of the ongoing land-use conversion on water quality. This report presents water-quality information and physical characteristics for five sites in or near the Treyburn development for 1994-98, and trend and load information for five sites for various periods during 1988-98.

The five sites monitored were chosen to characterize either baseline water quality or water quality from different land uses in and near the development. Flat River tributary drains an undeveloped area within the Treyburn development that provides a baseline for comparing the effects of developed areas. Little River tributary drains a relatively small area with private, singlefamily residences and a golf course. Little River downstream from the Little River tributary characterizes water quality of the reservoir outflow and the forested and residential areas in the western part of the Treyburn development area. Mountain Creek is unaffected by development in Treyburn and characterizes water quality where agricultural land is being converted to urban land. Flat River at Bahama also is unaffected by development in Treyburn and characterizes water quality where agricultural land is being converted to forest or urban land use.
Water-quality data were collected at regular intervals, approximately once per month and during selected storm events. Samples were analyzed for nutrients and suspended sediment. Samples for analyses of synthetic organic compounds and metals and trace elements normally were collected once per year at low flow and twice per year during runoff conditions. Continuous discharge was recorded at all sites except Little River tributary. Water temperature, $\mathrm{pH}$, specific conductance, and dissolved oxygen were determined in the field at the time of sample collection. Chemical analyses were performed at the USGS National WaterQuality Laboratory in Denver.

Channel geometry was assessed at eight sites in February 1997. At each site, at least three points along the reach were selected for cross-section measurement. Locations of cross sections to be surveyed were selected to represent prominent geomorphic features, such as meander bends and point bars. Data for several stream characteristics were derived from cross-section information.

Streamflow statistics were calculated at the four sites equipped with streamflow gages. Higher than average streamflow occurred during September 1996 as a result of Hurricane Fran, which resulted in a monthly average that was more than two orders of magnitude greater than the September long-term average. Lower than average streamflow occurred during most of 1994 (10 of 12 months) and 1995 (9 of 12 months). Streamflow during 1997 was near the long-term average. The mean annual runoff at the gaged sites ranged from 0.97 to $1.17\left(\mathrm{ft}^{3} / \mathrm{s}\right) / \mathrm{mi}^{2}$. For the purpose of constituent load estimation, continuous record of discharge for the Little River tributary site was estimated from discharge records for Flat River tributary.

The composition of water at each site was characterized with analyses of major ions from samples collected in June 1991. All sites in the study have calcium and bicarbonate water type. The substantially more 
mineralized water from Little River tributary compared to other sites in the study probably indicates the effects on water quality of land disturbance and nonpoint sources from the residential area and the golf course.

Measurements of specific conductance ranged from 29 to $265 \mu \mathrm{S} / \mathrm{cm}$. Highest specific conductance occurred in Little River tributary (median $147 \mu \mathrm{S} / \mathrm{cm}$ ), followed by Mountain Creek (median $100 \mu \mathrm{S} / \mathrm{cm}$ ). Measurements at the remaining sites were similar (median 72 to $76 \mu \mathrm{S} / \mathrm{cm}$ ). For Little River tributary, the slope of the specific conductance and unit discharge relation is much steeper than at the other sites. This difference in the quality of water at low flow, as was noted above, may be due to the greater proportion of land disturbance in this basin or applications of fertilizers and other chemicals to the golf course and residential lawns.

There was little variation in $\mathrm{pH}$ among sites in the study. Overall, $\mathrm{pH}$ ranged from 5.7 to 7.5 , and medians of $\mathrm{pH}$ ranged from 6.8 to 7.1. Dissolved oxygen concentrations ranged from 2.2 to $13.7 \mathrm{mg} / \mathrm{L}$. Median concentrations ranged from 8.2 to $9.0 \mathrm{mg} / \mathrm{L}$.

Sampled suspended-sediment concentrations ranged from less than 1 to $581 \mathrm{mg} / \mathrm{L}$ and were fairly uniform among the study sites. Median concentrations ranged from 12 to $21 \mathrm{mg} / \mathrm{L}$. Because of reservoir trapping, the lowest concentrations of suspended sediment occurred in Little River downstream from the Little River Reservoir. Selected stream samples were analyzed for aluminum, iron, manganese, arsenic, cadmium, chromium, cobalt, copper, lead, mercury, molybdenum, nickel, selenium, silver, and zinc. Few metals and trace elements, except aluminum, iron, and manganese, were detected in concentrations that exceeded the laboratory reporting levels or the water-quality criteria. The reporting level for silver $(1 \mu \mathrm{g} / \mathrm{L})$ was greater than the action level of $0.06 \mu \mathrm{g} / \mathrm{L}$; both the action level and the reporting level were exceeded at Little River tributary. Lead, nickel, and chromium were detected at all but the Little River site, but detections were less than half the water-quality criterion. Sediment trapping in Little River Reservoir may reduce the concentrations of metals that adsorb to sediment particles. Copper was detected at least once at each site and exceeded the action level at Little River tributary $(8 \mu \mathrm{g} / \mathrm{L})$. Copper is a component of some fungicides and may be present because of fungicide use on residential lawns or the golf course. Zinc was detected at Little River tributary, Flat River tributary, and Mountain Creek, but detections were less than half the action level. The number and magnitude of detections of chromium, copper, lead, nickel, and zinc were far smaller than those reported for Charlotte urban and mixed land-use watersheds. Aluminum, iron, and manganese are found in abundance in the ambient environment. Concentrations generally were greater in Mountain Creek and Little River tributary than in Flat River tributary.

The lowest range and median concentrations of total organic nitrogen, nitrite plus nitrate, ammonia, and total phosphorus occurred in the relatively undisturbed, forested Flat River tributary site. The maximum concentration of organic nitrogen $(1.97 \mathrm{mg} / \mathrm{L})$ occurred in Mountain Creek, and the maximum median concentration occurred in Little River. Ammonia concentrations ranged from less than 0.01 to $0.36 \mathrm{mg} / \mathrm{L}$. Median concentrations were near the reporting level. There were no significant differences between sites. Nitrate concentrations ranged from less than 0.05 to $0.80 \mathrm{mg} / \mathrm{L}$. The maximum concentrations occurred at Flat River and Little River tributary $(0.80$ and $0.79 \mathrm{mg} / \mathrm{L}$, respectively). The greatest median nitrate concentration occurred in Mountain Creek.

Total phosphorus concentrations ranged from less than 0.01 to $0.87 \mathrm{mg} / \mathrm{L}$. The maximum concentration occurred at Little River tributary. Median concentrations were similar at each site, and only concentrations at Little River tributary were significantly greater than those at Flat River tributary $(p<0.05)$. Phosphorus concentrations at all of the Treyburn study sites were low compared to samples collected at sites in the coastal region of North Carolina as part of the NAWQA Albemarle-Pamlico study, which typically exceeded $0.1 \mathrm{mg} / \mathrm{L}$. Orthophosphate concentrations ranged from less than 0.01 to $0.76 \mathrm{mg} / \mathrm{L}$ as phosphorus. The maximum orthophosphate concentrations occurred in Little River tributary where concentrations were significantly higher than at all of the other sites. The greater orthophosphate concentrations in Little River tributary may be due to applications of fertilizers associated with residential and golf-course land uses.

Samples for analysis of selected pesticides were collected in the spring and early summer of water years 1996-98 at Mountain Creek, Little River tributary, and Flat River tributary. A total of 119 different pesticides were tested, of which 12 were found at concentrations that exceeded the laboratory reporting levels. All of the pesticides were detected in low concentrations at the three study sites. The greatest number of pesticides were detected in Little River tributary (10 of the 11 compounds). This is also where the highest concentrations were detected, with the exception of atrazine and 2,4-D, which were found in greater concentrations in Mountain Creek. Five of six samples collected at Little River tributary had detectable concentrations of simazine, atrazine, and pendimethalin — all herbicides that are used to control 
weeds in crops or turf. Little River tributary drains a small watershed with a golf course and residential land use.

Examining channel response to natural or manmade changes in factors, such as discharge, channel gradient, and sediment transport, is not only important to understanding the effects of channel alterations, such as bridges, but also is critical to understanding the relations among physical stream features and aquatic biota. Examination of mean bank angle and mean channel width-to-depth ratios indicated that the sites could be separated into three groups - sites with mean bank angles greater than 40 degrees and width-to-depth ratios less than 10; sites with mean bank angles less than 40 degrees and width-to-depth ratios from 10 to 20; and sites with mean bank angles less than 40 degrees and width-to-depth ratios greater than 20. Channel gradient ranged from 0.04 to 1.63 percent. Mean cross sectional area ranged from 31.0 to $1,226.7 \mathrm{ft}^{2}$. These results provide quantitative baseline data and repeatable procedures for additional future cross-section evaluation upon which to base management decisions regarding streams within the Treyburn development.

Benthic macroinvertebrates integrate the effects of stresses, such as land-use changes, chemical contamination, habitat destruction, and sedimentation over time, and provide a broad measure of their aggregate effects. Three samples were collected from each of 10 sites, representing areas designated richest targeted habitats (RTH), depositional targeted habitats (DTH), and qualitative multihabitats (QMH). Samples from most sites were collected during February 13-15, 1995. Samples from two sites were collected on February 21, 1995. Stream temperatures ranged from 0.5 to $9^{\circ} \mathrm{C}$. Total taxa richness; Ephemeroptera, Plecoptera, and Trichoptera (EPT) richness; and North Carolina Biotic Index (NCBI) are macroinvertebrate-based water-quality assessment tools that were used to rate water-quality conditions.

Over 230 taxa were identified from these 10 sites. The NCBI ratings ranged from 4.98 (excellent) to 6.82 (fair). Total taxa richness at each site ranged from 49 to 108. River sites tended to have higher total taxa richness (91-108) than did the small, intermittent streams (49-84) or the midsize Mountain Creek (85). Intermittent streams represent fairly hostile environments for most aquatic organisms, particularly for long-lived organisms, such as large stoneflies, dragonflies, dobsonflies, and molluscs. RTH samples typically were more than twice as rich as DTH samples and represented from 51 to 75 percent of the taxa found at each site (mean of 62 percent). DTH samples represented only 3 to 56 percent of the taxa at each site (mean of 21.5 percent).
The Eno River tributary (site 2T, industrial site) lacked many of the mayfly taxa that are present at the Flat River tributary (site 1T, undeveloped site). Mayflies are very sensitive to metals contamination, and their absence may indicate a possible problem. The supporting chemical information is not available for site $2 \mathrm{~T}$, and additional study would be needed to substantiate this possibility. Sites $8 \mathrm{~T}$ and $8 \mathrm{~TB}$ (golf-course and residential sites) tended to support more different types of sensitive invertebrates, such as EPT taxa, than the forested and residential sites, although the abundances of EPT taxa were very similar. Land-use effects were not evident based on a comparison among these sites.

Indirect gradient analysis was used to uncover patterns in the distribution of invertebrates and examine the relations between these patterns and physical and chemical site characteristics determined in this study. The analysis underscored the strong influence that drainagebasin size has on the distribution of invertebrates. This analysis supports the contention that, biologically, these sites represent three groups - small, intermittent streams; midsize streams; and rivers. The dominant factors accounting for the distribution of benthic invertebrates are associated with natural factors, such as basin size, rather than land use.

Constituent load was calculated for nutrients, suspended sediment, and total organic carbon. Loads were calculated based on a regression analysis of continuous streamflow record and periodic water-quality sample analyses for water years 1989-98. The best-fit regression model was selected for each constituent and each site. Annual load estimates were normalized based on drainage area to determine annual constituent yield in tons per square mile.

The median annual suspended-sediment loads ranged from 135 to 19,100 tons. The extreme flooding caused by Hurricane Fran in early September 1996 resulted in an estimated 1-day suspended-sediment load at Flat River at Bahama of 211,000 tons, which exceeded the median annual load by 20 times. The maximum annual suspended-sediment yield was from Mountain Creek ( 422 tons $/ \mathrm{mi}^{2}$ ), and the minimum yield was at Little River (32 tons $/ \mathrm{mi}^{2}$ ) where sediments are trapped in the Little River Reservoir just upstream. The annual suspended-sediment yield at Mountain Creek was similar to the annual yield reported for a mixed land-use site in Charlotte. The annual suspended-sediment yield at Flat River tributary was high compared to other forested basins in the Piedmont but was comparable to annual yields reported for mixed and agricultural land-use basins in the Piedmont. 
Annual median total nitrogen loads ranged from 0.724 ton at Flat River tributary to 134 tons at Flat River. The median annual total nitrogen yield ranged from $0.635 \mathrm{ton} / \mathrm{mi}^{2}$ at Flat River tributary to 1.63 tons $/ \mathrm{mi}^{2}$ at Little River tributary. Mountain Creek had the second highest yield-1.19 ton $/ \mathrm{mi}^{2}$. Flat River and Little River each had yields near 0.9 ton $/ \mathrm{mi}^{2}$, indicating a minimal trapping effect for nitrogen in the Little River Reservoir. Median annual nitrite-plus-nitrate yields ranged from 0.126 ton $/ \mathrm{mi}^{2}$ at Flat River tributary to 0.408 ton $/ \mathrm{mi}^{2}$ at Little River tributary. Nitrite plus nitrate accounted for less than 20 percent of the annual total nitrogen yield at Flat River tributary but more than 33 percent of the annual yield at Mountain Creek and Flat River. The total nitrogen yield for the forested Flat River tributary was less than half that reported for the mixed forested and agricultural watersheds in the Piedmont of North Carolina. The annual median yield of 1.63 tons $/ \mathrm{mi}^{2}$ at Little River tributary was near that reported for a very small residential land-use watershed in the Charlotte area $\left(1.7\right.$ tons $\left./ \mathrm{mi}^{2}\right)$ and for larger forested and agricultural land-use watersheds in the Raleigh-Durham-Chapel Hill area $\left(1.5\right.$ tons $\left./ \mathrm{mi}^{2}\right)$.

Median annual total phosphorus loads ranged from 0.052 ton at Flat River tributary to 12.2 tons at Flat River. The load from Little River tributary was an order of magnitude greater than that from Flat River tributary. Median annual total phosphorus yields ranged from 0.046 to $0.619 \mathrm{ton} / \mathrm{mi}^{2}$. The greatest annual yield was for Little River tributary - almost three times greater than the next highest annual yield of $0.209 \mathrm{ton} / \mathrm{mi}^{2}$ for Mountain Creek. Annual total phosphorus yields exceeding $0.3 \mathrm{ton} / \mathrm{mi}^{2}$ were reported for two mixed land-use sites in the upper Neuse River Basin and Charlotte, and for a very small residential and industrial site in Charlotte. The annual yield for Mountain Creek closely matched those reported for two similar-size mixed forest and agricultural land-use sites in the Jordan Lake watershed. Median annual orthophosphate yields ranged from 0.022 to $0.379 \mathrm{ton} / \mathrm{mi}^{2}$. The smallest annual yield was for Flat River tributary, but the annual yields were not much greater for Flat River, Little River, and Mountain Creek-less than 0.05 ton $/ \mathrm{mi}^{2}$. Orthophosphate accounted for more than half of the phosphorus yield for Little River tributary, which has a greater density of residential land use in addition to a golf course.

Applications of fertilizers associated with these land uses may account for the greater load of phosphorus in Little River tributary.

Total organic carbon data, sufficient for loading estimations, were available for Flat River tributary, Mountain Creek, and Flat River. The annual total organic carbon yield for Flat River tributary was substantially more than the yields for Mountain Creek and Flat River tributary. This may be due, in part, to the smaller size of the drainage basin and to the forested setting that contributes organic material to the stream channel in the form of organic debris. However, total organic carbon yields of 15.5 to 21 tons $/ \mathrm{mi}^{2}$ were reported for mixed, residential, and combined residential and industrial land uses in the Charlotte metropolitan area.

Temporal trends in selected water-quality constituents were tested by using the seasonal Kendall trend test. The only significant trend, at alpha $=0.05$, was a downward trend for total nitrogen, ammonia plus organic nitrogen, and organic nitrogen at Flat River tributary. The trend slope was small, only $0.019 \mathrm{mg} / \mathrm{L}$ per year, or less than 9 percent of the median organic nitrogen concentration. No trend was observed for nitrite plus nitrate or for ammonia, indicating that the downward trend in total nitrogen was due only to organic nitrogen.

\section{REFERENCES}

Bales, J.D., and Childress, C.J.O., 1996, Aftermath of Hurricane Fran in North Carolina-Preliminary data on flooding and water quality: U.S. Geological Survey Open-File Report 96-499, 6 p.

Bales. J.D., Weaver, J.C., and Robinson, J.B., 1999, Relation of land use to streamflow and water quality at selected sites in the City of Charlotte and Mecklenburg County, North Carolina, 1993-98: U.S. Geological Survey Water-Resources Investigations Report 99-4180, $95 \mathrm{p}$.

Barbour, M.T., Gerritsen, Jeroen, Snyder, B.D., and Stribling, J.B., 1999, Rapid bioassessment protocols for use in wadeable streams and rivers-Periphyton, benthic macroinvertebrates, and fish ( $2 \mathrm{~d}$ ed.): Washington, D.C., U.S. Environmental Protection Agency, Office of Water, EPA 841-B-99-002.

Beschta, R.L., and Platts, W.S., 1986, Morphological features of small streams - Significance and function: Water Resources Bulletin, v. 22, p. 369-379.

Britton, L.J., and Greeson, P.E., eds., 1989, Methods for collection and analyses of aquatic biological and microbiological samples: U.S. Geological Survey Techniques of Water-Resources Investigations, book 5, chap. A4, 363 p.

Childress, C.J.O., and Bathala, Neeti, 1997, Water-quality trends for streams and reservoirs in the Research Triangle area of North Carolina, 1983-95: U.S. Geological Survey Water-Resources Investigations Report 97-4061, 18 p. 
Childress, C.J.O., and Treece, M.W., Jr., 1996, Water and bedmaterial quality of selected streams and reservoirs in the Research Triangle area of North Carolina, 1988-94: U.S. Geological Survey Water-Resources Investigations Report 95-4282, 79 p.

Cuffney, T.F., Gurtz, M.E., and Meador, M.R., 1993, Methods for collecting benthic invertebrate samples as part of the National Water-Quality Assessment Program: U.S. Geological Survey Open-File Report 93-406, 66 p.

Davis, W.S., Snyder, B.D., Stribling, J.B., and Stoughton, C., 1996, Summary of State biological assessment programs for stream and wadeable rivers: Washington, D.C., U.S. Environmental Protection Agency, Office of Policy, Planning, and Evaluation, EPA 230-R-96-007.

Edwards, T.K., and Glysson, G.D., 1988, Field methods for measurements of fluvial sediment: U.S. Geological Survey Open-File Report 86-531, 118 p.

Emmett, W.W., 1975, The channels and waters of the upper Salmon River area, Idaho: U.S. Geological Survey Professional Paper 870-A, 116 p.

Environmental Systems Research Institute, 1992, Understanding GIS - The ARC/INFO method: Redlands, Calif., Environmental Systems Research Institute, $450 \mathrm{p}$.

Fausch, K.D., Lyons, J., Karr, J.R., and Angermeier, P.L., 1990, Fish communities as indicators of environmental degradation, in Adams, S.M., ed., Biological indicators of stress in fish: Bethesda, Md., American Fisheries Society, p. 123-144.

Fishman, M.J., ed., 1993, Methods of analysis by the U.S. Geological Survey National Water-Quality Laboratory - Determination of inorganic and organic constituents in water and fluvial sediments: U.S. Geological Survey Open-File Report 93-125, 217 p.

Fishman, M.J., and Friedman, L.C., eds., 1989, Methods for determination of inorganic substances in water and fluvial sediments: U.S. Geological Survey Techniques of Water-Resources Investigations, book 5, chap. A1, $545 \mathrm{p}$.

Fitzpatrick, F.A., Waite, I.R., D’Arconte, P.J., Meador, M.R., Maupin, M.A., and Gurtz, M.E., 1998, Revised methods for characterizing stream habitat in the National WaterQuality Assessment Program: U.S. Geological Survey Water-Resources Investigations Report 98-4052, 67 p.

Garrett, R.G., and Bales, J.D., 1995, Water-quality characteristics of streams in the Treyburn development area of Falls Lake watershed, North Carolina, 1988-93: U.S. Geological Survey Water-Resources Investigations Report 95-4094, 79 p.

Garrett, R.G., Taylor, J.E., and Middleton, T.L., 1994, Waterquality data for selected North Carolina streams and reservoirs in the Triangle Area Water Supply Monitoring Project, 1988-92: U.S. Geological Survey Open-File Report 94-379, 255 p.
Gilroy, E.J., Hirsch, R.M., and Cohn, T.A., 1990, Mean square error of regression-based constituent transport estimates: Water Resources Research, v. 36, no. 9, p. 2069-2077.

Gordon, N.D., McMahon, T.A., and Finlayson, B.L., 1992, Stream hydrology: New York, John Wiley and Sons, $526 \mathrm{p}$.

Guy, H.P., 1969, Laboratory theory and methods for sediment analyses: U.S. Geological Survey Techniques of WaterResources Investigations, book 5, chap. C1, 58 p.

Harned, D.A., McMahon, Gerard, Spruill, T.B., and Woodside, M.D., 1995, Water-quality assessment of the Albemarle-Pamlico drainage basin, North Carolina and Virginia-Characterization of suspended sediment, nutrients, and pesticides: U.S. Geological Survey Open-File Report 95-191, 131 p.

Heede, B.H., and Rinne, J.N., 1990, Hydrodynamic and fluvial morphologic processes - Implications for fisheries management and research: North American Journal of Fisheries Management, v. 10, p. 249-268.

Helsel, D.R., and Hirsch, R.M., 1992, Statistical methods in water resources: Amsterdam, Elsevier Science Publishers, 529 p.

Hirsch, R.M., Slack, J.R., and Smith, R.A., 1992, Techniques of trend analysis for monthly water quality data: Water Resources Research, v. 18, p. 107-121.

Hogan, D.L., and Church, Michael, 1989, Hydraulic geometry in small coastal streams-Progress toward quantification of salmonid habitat: Canadian Journal of Fisheries and Aquatic Sciences, v. 46, no. 5, p. 844-852.

Koltun, G.F., Gray, J.R., and McElhone, T.J., 1994, User's manual for SEDCALC, a computer program for computation of suspended-sediment discharge: U.S. Geological Survey Open-File Report 94-459, 46 p.

Kovich, W.L., 1998, MVSP - A multivariate statistical package for Windows, ver. 3.0: Pentraeth, Wales, U.K., Kovach Computing Services.

Lenat, D.R., 1988, Water quality assessment of streams using a qualitative collection method for benthic macroinvertebrates: Journal of the North American Benthological Society, v. 7, p. 222-233.

Leopold, L.B., 1994, A view of the river: Cambridge, Mass., Harvard University Press, 298 p.

Leopold, L.B., Wolman, M.G., and Miller, J.P., 1964, Fluvial processes in geomorphology: New York, Dover Publications, $522 \mathrm{p}$.

Merritt, R.W., and Cummins, K.W., eds., 1996, An introduction to the aquatic insects of North America (3d ed.): Dubuque, Iowa, Kendall/Hunt Publishing Company, $862 \mathrm{p}$.

Mueller, D.K., Hamilton, P.A., Helsel, D.R., Hitt, K.J., and Ruddy, B.C., 1995, Nutrients in ground water and surface water of the United States - An analysis of data through 1992: U.S. Geological Survey Water-Resources Investigations Report 95-4031, 74 p. 
National Oceanic and Atmospheric Administration, 1988-92 [published annually], Climatological data annual summaries - North Carolina: Asheville, N.C., National Climatic Data Center.

North Carolina Department of Environment, Health, and Natural Resources, 1993, Neuse River basinwide water quality management plan: Raleigh, North Carolina Division of Environmental Management, [variously paged].

North Carolina Department of Environment and Natural Resources, 1997a, Administrative code sections 15A NCAC 2B.0100-Procedures for assignment of water quality standards; and 15A NCAC 2B.0200Classifications and water quality standards applicable to surface waters and wetlands of North Carolina: Raleigh, North Carolina Division of Water Quality, 39 p.

1997b, Standard operating procedures_-Biological monitoring: accessed November 2000 at <http://www.esb.enr.state.nc.us/BAUwww/ BethosSOP.pdf> .

1999, Neuse River basinwide water quality plan: Raleigh, North Carolina Division of Water Quality, $214 \mathrm{p}$.

North Carolina Division of Water Quality, 1992, North

Carolina waterbodies reports: accessed June 8, 2001, at <http://h2o.ehnr.state.nc.us/bims/reports/ basinsandwaterbodies/hydroNeuse.pdf $>$.

1997, Standard operating procedures - Biological monitoring: Raleigh, North Carolina Department of Environment, Health, and Natural Resources, 28 p.

2000, Water quality progress in North Carolina, 1998-99, 305(b) report: Raleigh, North Carolina Department of Environment and Natural Resources.

North Carolina Office of State Budget, Planning and Management, 1998, 1998 Municipal population estimates: accessed June 2000 at <http:// www.osbpm.state.nc.us/demog/muntot98.html> .

Olson-Rutz, K.M., and Marlow, C.B., 1992, Analysis and interpretation of stream channel cross-sectional data: North American Journal of Fisheries Management, v. 12, p. $55-61$.

Rantz, S.E., and others, 1982, Measurement and computation of streamflow: U.S. Geological Survey Water-Supply Paper 2175, $631 \mathrm{p}$.

Simmons, C.E., 1993, Sediment characteristics of North Carolina streams, 1970-79: U.S. Geological Survey Water-Supply Paper 2364, 84 p.
Snedecor, G.W., and Cochran, W.G., 1980, Statistical methods: Ames, Iowa, The Iowa State University Press, 507 p.

Swancar, Amy, 1996, Water quality, pesticide occurrence, and effects of irrigation with reclaimed water at golf courses in Florida: U.S. Geological Survey Water-Resources Investigations Report 95-4250, 85 p.

ter Braak, C.J.F., 1987, Ordination, chap. 5, in Jongman, R.H.G., ter Braak, C.J.F., and van Tongeren, O.F.R., eds., Data analysis in community and landscape ecology: Wageningen, Netherlands, Center for Agricultural Publishing and Documentation.

U.S. Department of Agriculture, Soil Conservation Service, 1976, Soil survey of Durham County, North Carolina: Washington, D.C., U.S. Government Printing Office, $74 \mathrm{p}$.

U.S. Department of Health and Human Services, 1999, Top 20 hazardous substances on the Agency for Toxic Substances and Disease Registry/U.S. Environmental Protection Agency priority list for 1999: accessed June 19, 2000, at <http://www.atsdr.cdc.gov/ cxcx3.html>.

U.S. Environmental Protection Agency, 1999, Major environmental laws, Clean Water Act, 33 U.S.C. s/s 1251 et seq. (1977): accessed Dec. 20, 1999, at <http://www.epa.gov/region5/defs/html/cwa.htm>. 2000, Nutrient criteria technical guidance manual, lakes and reservoirs (1st ed.): Washington, D.C., U.S. Environmental Protection Agency, EPA-822-B00-001.

U.S. Geological Survey, 1999, Strategic directions for the Water Resources Division, 1998-2008: U.S. Geological Survey Open-File Report 99-249, 27 p.

Vannote, R.L., Minshall, G.W., Cummins, K.W., Sedell, J.R., and Cushing, C.E., 1980, The river continuum concept: Canadian Journal of Fisheries and Aquatic Sciences, v. 37, p. 130-137 [variously paged].

Ward, J.R., and Harr, C.A., eds., 1990, Methods for collection and processing of surface-water and bed-material samples for physical and chemical analyses: U.S. Geological Survey Open-File Report 90-140, 71 p.

Wershaw, R.L., Fishman, M.J., Grabbe, R.R., and Lowe, L.E., 1987, Methods for the determination of organic substances in water and fluvial sediments: U.S. Geological Survey Techniques of Water-Resources Investigations, book 5, chap. A3, 80 p.

Wilde, F.D., and others, eds., 1998, National field manual for the collection of water-quality data: U.S. Geological Survey Techniques of Water-Resources Investigations, book 9, chaps. A1-A9. 


\section{APPENDIX TABLES}


Appendix Table 1. Cross-section survey data collected in February 1997 at eight sites in the Treyburn development study area, North Carolina

[HUB, turning point; - , no notes; TOB, top of bank; EOW, edge of water; WS, water surface; EOC, edge of channel; SR, secondary road; PK, nail (with, as in PK57, or without an assigned number); TOS, top of slope; MP, midpoint; TORB, top of right bank; TOLB, top of left bank; TRIB, tributary; EOB, edge of bank; RM, reference mark]

\begin{tabular}{|c|c|c|c|c|}
\hline $\begin{array}{l}\text { Data } \\
\text { count }\end{array}$ & $\begin{array}{c}\text { Local } x \\
\text { coordinate }\end{array}$ & $\begin{array}{l}\text { Local y } \\
\text { coordinate }\end{array}$ & $\begin{array}{c}\text { Local } \\
\text { elevation, } \\
\text { in feet, above } \\
\text { arbitrary datum }\end{array}$ & Notes \\
\hline $\begin{array}{l}\text { Benchma } \\
\text { of the cro } \\
\text { sea level. }\end{array}$ & $\begin{array}{l}1 \mathrm{~T}-020 \\
\text { rass disk on t } \\
\text { ions is } 36^{\circ} 07^{\prime} \\
\text { elevation mus }\end{array}$ & $\begin{array}{l}\text { 12, Flat } \\
\text { ke Michie dan } \\
\text { titude, } \mathbf{7 8}^{\circ} \mathbf{5 0}^{\prime} \\
\text { sted by subtr }\end{array}$ & $\begin{array}{l}\text { er tributar } \\
\text { of elevator hot } \\
\text { " longitude. El } \\
\text { g } 228.79 \text { feet to }\end{array}$ & $\begin{array}{l}\text { ear Willardville, N.C. } \\
\text { levation is } 342.17 \text { feet; general location } \\
\text { on at HUB is } 271.21 \text { feet above mean } \\
\text { in elevation above mean sea level. }\end{array}$ \\
\hline 1 & 10000.000 & 10000.000 & 500.00 & HUB \\
\hline 2 & 10100.000 & 10000.000 & 500.00 & - \\
\hline 3 & 9974.853 & 9915.556 & 499.27 & Cross section 1 . \\
\hline 4 & 9988.011 & 9943.762 & 497.58 & Cross section 1 . \\
\hline 5 & 10001.391 & 9966.981 & 497.52 & Cross section 1 . \\
\hline 6 & 10010.728 & 9980.703 & 498.38 & Cross section 1 , TOB. \\
\hline 7 & 10012.213 & 9981.632 & 494.95 & Cross section 1, EOW. \\
\hline 8 & 10013.939 & 9983.585 & 494.39 & Cross section 1 \\
\hline 9 & 10015.669 & 9984.847 & 494.64 & Cross section 1 . \\
\hline 10 & 10017.254 & 9986.496 & 494.97 & Cross section 1, EOW. \\
\hline 11 & 10020.232 & 9988.288 & 497.20 & Cross section 1 , TOB. \\
\hline 12 & 10025.325 & 9994.523 & 497.66 & Cross section 1 \\
\hline 13 & 10035.099 & 10011.909 & 498.76 & Cross section 1 . \\
\hline 14 & 10029.794 & 9979.686 & 497.68 & Cross section 1 , TOB. \\
\hline 15 & 10030.676 & 9978.042 & 494.82 & Cross section 1, EOW. \\
\hline 16 & 10030.275 & 9969.213 & 494.98 & Cross section 1, EOW. \\
\hline 17 & 10029.874 & 9965.142 & 498.47 & Cross section 1 , TOB. \\
\hline 18 & 10055.719 & 9955.187 & 498.83 & Cross section 2 \\
\hline 19 & 10052.345 & 9972.285 & 498.18 & Cross section 2, TOB. \\
\hline 20 & 10050.827 & 9976.312 & 495.76 & Cross section 2, EOW. \\
\hline 21 & 10050.134 & 9979.921 & 494.88 & Cross section 2, WS. \\
\hline 22 & 10050.201 & 9982.021 & 494.63 & Cross section 2. \\
\hline 23 & 10050.202 & 9983.029 & 495.07 & Cross section 2, EOW. \\
\hline 24 & 10049.245 & 9985.062 & 498.25 & Cross section 2, TOB. \\
\hline 25 & 10048.957 & 9996.463 & 497.73 & Cross section 2 \\
\hline 26 & 10050.676 & 10020.771 & 499.12 & Cross section 2. \\
\hline 27 & 10077.155 & 9993.476 & 496.05 & Center ditch. \\
\hline 28 & 10067.852 & 9983.109 & 495.23 & Center ditch, EOW. \\
\hline 29 & 10061.689 & 9977.364 & 495.22 & EOW. \\
\hline 30 & 10058.551 & 9972.321 & 498.40 & TOB. \\
\hline 31 & 9997.120 & 9908.569 & 497.99 & Cross section 3 . \\
\hline 32 & 10036.716 & 9933.580 & 498.55 & Cross section 3 . \\
\hline 33 & 10053.671 & 9939.439 & 499.34 & Cross section 3 , TOB. \\
\hline 34 & 10058.369 & 9940.655 & 495.73 & Cross section 3 , EOC. \\
\hline 35 & 10060.285 & 9940.730 & 495.76 & Cross section 3, EOW. \\
\hline 36 & 10064.921 & 9941.687 & 495.70 & Cross section 3 . \\
\hline 37 & 10066.809 & 9942.213 & 495.44 & Cross section 3, EOW. \\
\hline 38 & 10067.928 & 9942.667 & 498.68 & Cross section 3 , TOB. \\
\hline 39 & 10100.664 & 9964.301 & 498.09 & Cross section 3 . \\
\hline
\end{tabular}


Appendix Table 1. Cross-section survey data collected in February 1997 at eight sites in the Treyburn development study area, North Carolina-Continued

[HUB, turning point; - , no notes; TOB, top of bank; EOW, edge of water; WS, water surface; EOC, edge of channel; SR, secondary road; PK, nail (with, as in PK57, or without an assigned number); TOS, top of slope; MP, midpoint; TORB, top of right bank; TOLB, top of left bank; TRIB, tributary; EOB, edge of bank; RM, reference mark]

\begin{tabular}{lllll}
\hline $\begin{array}{c}\text { Data } \\
\text { count }\end{array}$ & $\begin{array}{c}\text { Local } \mathbf{x} \\
\text { coordinate }\end{array}$ & $\begin{array}{c}\text { Local } \mathbf{c} \\
\text { coordinate }\end{array}$ & $\begin{array}{c}\text { Local } \\
\text { elevation, } \\
\text { in feet, above } \\
\text { arbitrary datum }\end{array}$ & Notes \\
\hline \multicolumn{5}{c}{ Site 1T-0208650112, Flat River tributary } \\
(Continued)
\end{tabular}


Appendix Table 1. Cross-section survey data collected in February 1997 at eight sites in the Treyburn development study area, North Carolina-Continued

[HUB, turning point; - , no notes; TOB, top of bank; EOW, edge of water; WS, water surface; EOC, edge of channel; SR, secondary road; PK, nail (with, as in PK57, or without an assigned number); TOS, top of slope; MP, midpoint; TORB, top of right bank; TOLB, top of left bank; TRIB, tributary; EOB, edge of bank; RM, reference mark]

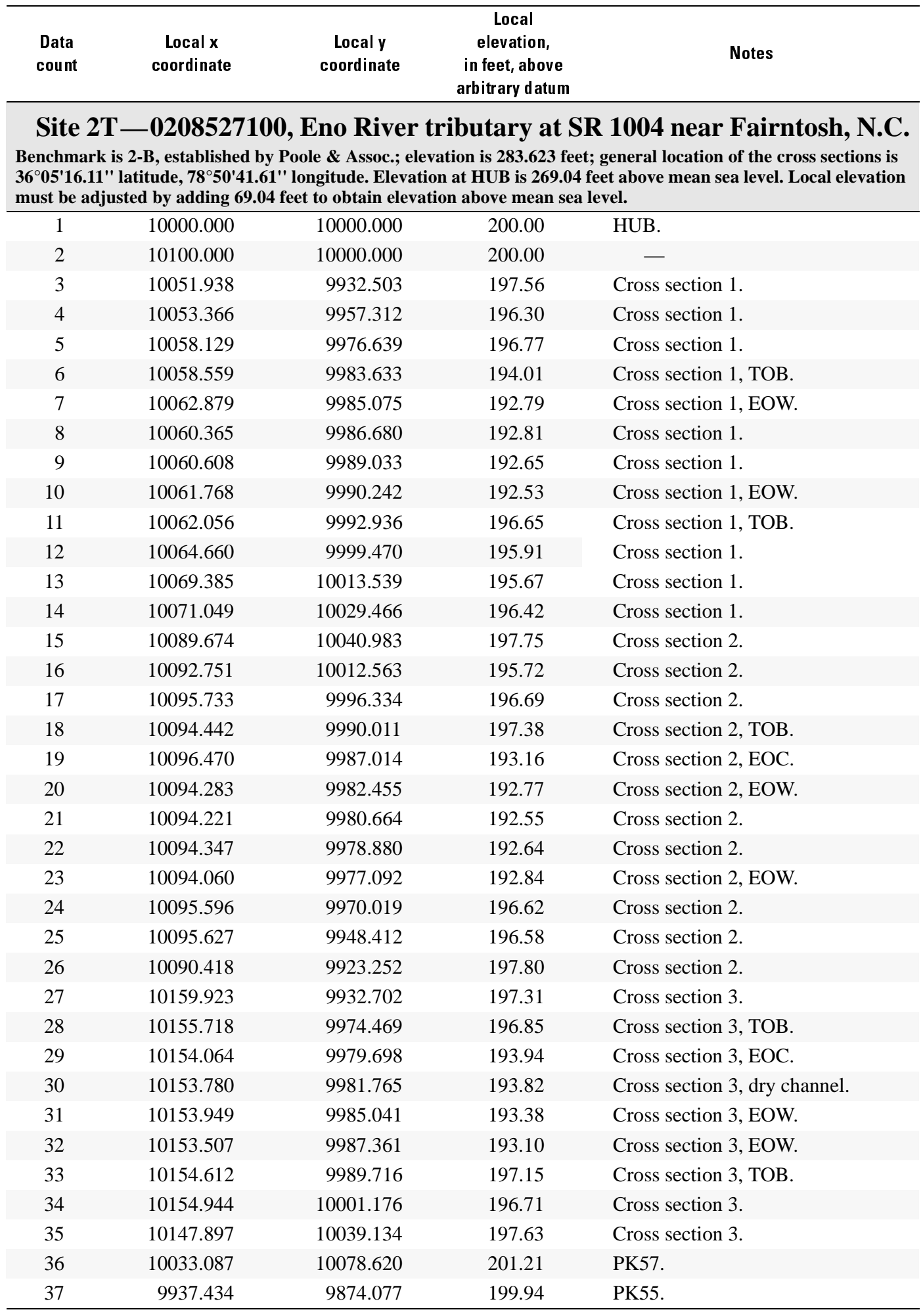


Appendix Table 1. Cross-section survey data collected in February 1997 at eight sites in the Treyburn development study area, North Carolina-Continued

[HUB, turning point; - , no notes; TOB, top of bank; EOW, edge of water; WS, water surface; EOC, edge of channel; SR, secondary road; PK, nail (with, as in PK57, or without an assigned number); TOS, top of slope; MP, midpoint; TORB, top of right bank; TOLB, top of left bank; TRIB, tributary; EOB, edge of bank; RM, reference mark]

\begin{tabular}{|c|c|c|c|c|}
\hline $\begin{array}{l}\text { Data } \\
\text { count }\end{array}$ & $\begin{array}{c}\text { Local } x \\
\text { coordinate }\end{array}$ & $\begin{array}{l}\text { Local y } \\
\text { coordinate }\end{array}$ & $\begin{array}{c}\text { Local } \\
\text { elevation, } \\
\text { in feet, above } \\
\text { arbitrary datum }\end{array}$ & Notes \\
\hline
\end{tabular}

Site 3T-0208524170, Little River tributary near Durham, N.C.

Benchmark is 7-A, established by Poole \& Assoc.; elevation is 371.753 feet; general location of the cross sections is $36^{\circ} 06^{\prime} 45.89^{\prime \prime}$ latitude, $7^{\circ} \mathbf{5 2}^{\prime} 59.45^{\prime \prime}$ longitude. Elevation at HUB is 363.85 feet above mean sea level. Local elevation must be adjusted by adding 263.85 feet to obtain elevation above mean sea level.

\begin{tabular}{|c|c|c|c|c|}
\hline 1 & 10000.000 & 10000.000 & 100.00 & HUB. \\
\hline 2 & 10100.000 & 10000.000 & 100.00 & - \\
\hline 3 & 9916.188 & 9984.084 & 102.16 & Cross section 1 , TOS. \\
\hline 4 & 9937.299 & 9995.701 & 99.45 & Cross section 1, MP. \\
\hline 5 & 9958.976 & 10004.827 & 97.91 & Cross section 1 , TOB. \\
\hline 6 & 9960.554 & 10005.289 & 96.72 & Cross section 1, EOW. \\
\hline 7 & 9964.015 & 10006.700 & 96.47 & Cross section 1. \\
\hline 8 & 9966.191 & 10008.222 & 96.25 & Cross section 1 . \\
\hline 9 & 9969.856 & 10010.308 & 96.56 & Cross section 1 \\
\hline 10 & 9971.551 & 10011.415 & 96.79 & Cross section 1, EOW. \\
\hline 11 & 9976.301 & 10013.686 & 97.37 & Cross section 1 , TOB. \\
\hline 12 & 9983.732 & 10020.253 & 99.55 & Cross section 1 , TOB. \\
\hline 13 & 9998.098 & 10030.046 & 100.57 & Cross section 1 \\
\hline 14 & 10025.995 & 10049.355 & 102.32 & Cross section 1 . \\
\hline 15 & 10038.081 & 10063.367 & 104.54 & Cross section 1 . \\
\hline 16 & 10029.040 & 9958.058 & 104.56 & Cross section 2, MP. \\
\hline 17 & 10019.823 & 9952.803 & 100.09 & Cross section 2. \\
\hline 18 & 10015.497 & 9949.418 & 99.24 & Cross section 2 , TOB. \\
\hline 19 & 10011.884 & 9947.135 & 97.71 & Cross section 2, EOW. \\
\hline 20 & 10009.311 & 9945.291 & 97.51 & Cross section 2. \\
\hline 21 & 10006.144 & 9943.018 & 97.53 & Cross section 2 , WS. \\
\hline 22 & 10004.797 & 9941.863 & 97.47 & Cross section 2 . \\
\hline 23 & 10005.291 & 9937.880 & 97.53 & Cross section 2, EOW. \\
\hline 24 & 10005.174 & 9936.501 & 98.89 & Cross section 2, TOB. \\
\hline 25 & 9997.496 & 9934.783 & 99.31 & Cross section 2 . \\
\hline 26 & 9988.693 & 9929.275 & 99.94 & Cross section 2 \\
\hline 27 & 9972.548 & 9917.624 & 102.28 & Cross section 2. \\
\hline 28 & 9993.068 & 9858.965 & 103.38 & Cross section 3 . \\
\hline 29 & 10020.886 & 9871.285 & 101.97 & Cross section 3 . \\
\hline 30 & 10032.998 & 9877.325 & 101.30 & Cross section 3 , TOB. \\
\hline 31 & 10035.417 & 9879.135 & 99.00 & Cross section 3, EOW. \\
\hline 32 & 10038.466 & 9879.853 & 98.24 & Cross section 3, WS. \\
\hline 33 & 10040.219 & 9880.606 & 98.15 & Cross section 3 . \\
\hline 34 & 10042.571 & 9881.510 & 98.70 & Cross section 3 . \\
\hline 35 & 10047.099 & 9882.243 & 98.94 & Cross section 3, EOW. \\
\hline 36 & 10052.645 & 9883.675 & 101.28 & Cross section 3 , TOB. \\
\hline 37 & 10063.763 & 9888.363 & 104.04 & Cross section 3 . \\
\hline 38 & 10028.638 & 9986.369 & 105.34 & HUB. \\
\hline 39 & 10060.876 & 9971.023 & 112.33 & HUB. \\
\hline
\end{tabular}


Appendix Table 1. Cross-section survey data collected in February 1997 at eight sites in the Treyburn development study area, North Carolina-Continued

[HUB, turning point; - , no notes; TOB, top of bank; EOW, edge of water; WS, water surface; EOC, edge of channel; SR, secondary road; PK, nail (with, as in PK57, or without an assigned number); TOS, top of slope; MP, midpoint; TORB, top of right bank; TOLB, top of left bank; TRIB, tributary; EOB, edge of bank; RM, reference mark]

\begin{tabular}{|c|c|c|c|c|}
\hline $\begin{array}{l}\text { Data } \\
\text { count }\end{array}$ & $\begin{array}{l}\text { Local } x \\
\text { coordinate }\end{array}$ & $\begin{array}{l}\text { Local y } \\
\text { coordinate }\end{array}$ & $\begin{array}{c}\text { Local } \\
\text { elevation, } \\
\text { in feet, above } \\
\text { arbitrary datum }\end{array}$ & Notes \\
\hline
\end{tabular}

\section{Site 4T-0208521324, Little River at SR 1461 near Orange Factory, N.C.}

Benchmark is 2A (1461), established by the Department of Transportation; elevation is 423.335 feet; general location of the cross sections is $36^{\circ} 08^{\prime} 29.23^{\prime \prime}$ latitude, $7^{\circ} 5^{\prime}{ }^{\prime} 10.53^{\prime \prime}$ longitude. Elevation at HUB is 398.95 feet above mean sea level. Local elevation must be adjusted by subtracting 1.05 feet to obtain elevation above mean sea level.

\begin{tabular}{|c|c|c|c|c|}
\hline 1 & 10000.000 & 10000.000 & 400.00 & HUB. \\
\hline 2 & 10100.000 & 10000.000 & 400.00 & - \\
\hline 3 & 10052.779 & 9922.172 & 385.64 & WS. \\
\hline 4 & 10068.007 & 9812.090 & 388.18 & WS. \\
\hline 5 & 9969.999 & 9808.815 & 401.90 & Cross section 1 . \\
\hline 6 & 9984.743 & 9810.716 & 395.68 & Cross section 1 . \\
\hline 7 & 10002.657 & 9812.947 & 392.91 & Cross section 1. \\
\hline 8 & 10020.620 & 9815.479 & 391.94 & Cross section 1 , TORB. \\
\hline 9 & 10028.155 & 9814.984 & 388.28 & Cross section 1, EOW. \\
\hline 10 & 10040.651 & 9813.903 & 387.41 & Cross section 1 \\
\hline 11 & 10051.436 & 9814.405 & 387.94 & Cross section 1 . \\
\hline 12 & 10062.992 & 9814.860 & 388.42 & Cross section 1. \\
\hline 13 & 10074.486 & 9813.719 & 387.36 & Cross section 1 . \\
\hline 14 & 10083.729 & 9816.190 & 386.93 & Cross section 1. \\
\hline 15 & 10095.333 & 9816.313 & 387.61 & Cross section 1 . \\
\hline 16 & 10111.271 & 9817.450 & 388.56 & Cross section 1. \\
\hline 17 & 10118.996 & 9820.047 & 391.97 & Cross section 1 , TOLB. \\
\hline 18 & 10140.803 & 9820.785 & 393.05 & Cross section 1 \\
\hline 19 & 10163.555 & 9819.201 & 400.26 & Cross section 1 . \\
\hline 20 & 10178.389 & 9814.842 & 404.70 & Cross section 1 . \\
\hline 21 & 10171.447 & 9724.365 & 398.51 & Cross section 2. \\
\hline 22 & 10138.131 & 9722.699 & 393.30 & Cross section 2. \\
\hline 23 & 10115.397 & 9718.516 & 392.54 & Cross section 2 \\
\hline 24 & 10107.813 & 9718.567 & 388.76 & Cross section 2, EOW. \\
\hline 25 & 10093.923 & 9717.336 & 386.82 & Cross section 2 \\
\hline 26 & 10078.047 & 9716.624 & 386.45 & Cross section 2. \\
\hline 27 & 10072.472 & 9715.967 & 385.75 & Cross section 2 . \\
\hline 28 & 10044.618 & 9715.796 & 386.26 & Cross section 2 . \\
\hline 29 & 10034.592 & 9714.145 & 387.24 & Cross section 2. \\
\hline 30 & 10027.801 & 9712.952 & 387.79 & Cross section 2 . \\
\hline 31 & 10019.632 & 9709.648 & 392.68 & Cross section 2. \\
\hline 32 & 9998.824 & 9704.102 & 395.02 & Cross section 2 . \\
\hline 33 & 9978.258 & 9703.443 & 402.46 & Cross section 2 . \\
\hline 34 & 10201.832 & 9584.574 & 402.42 & Cross section 3 . \\
\hline 35 & 10167.876 & 9583.068 & 395.48 & Cross section 3 . \\
\hline 36 & 10127.086 & 9584.464 & 392.66 & Cross section 3 . \\
\hline 37 & 10106.551 & 9585.679 & 391.15 & Cross section 3 . \\
\hline 38 & 10103.800 & 9584.968 & 388.69 & Cross section 3 . \\
\hline 39 & 10090.691 & 9584.877 & 387.93 & Cross section 3 , WS. \\
\hline
\end{tabular}


Appendix Table 1. Cross-section survey data collected in February 1997 at eight sites in the Treyburn development study area, North Carolina-Continued

[HUB, turning point; - , no notes; TOB, top of bank; EOW, edge of water; WS, water surface; EOC, edge of channel; SR, secondary road; PK, nail (with, as in PK57, or without an assigned number); TOS, top of slope; MP, midpoint; TORB, top of right bank; TOLB, top of left bank; TRIB, tributary; EOB, edge of bank; RM, reference mark]

\begin{tabular}{llcll}
\hline $\begin{array}{l}\text { Data } \\
\text { count }\end{array}$ & $\begin{array}{c}\text { Local } \mathbf{x} \\
\text { coordinate }\end{array}$ & $\begin{array}{c}\text { Local } \mathbf{y} \\
\text { coordinate }\end{array}$ & $\begin{array}{c}\text { Local } \\
\text { elevation, } \\
\text { in feet, above } \\
\text { arbitrary datum }\end{array}$ & \multicolumn{1}{c}{ Notes } \\
\hline Site & $\mathbf{4 T}$ & $\mathbf{- 0 2 0 8 5 2 1 3 2 4 ,}$ Little River at SR 1461 & near Orange Factory, N.C. \\
(Continued) & \\
\hline 40 & 10067.707 & 9584.772 & 387.51 & Cross section 3. \\
41 & 10054.917 & 9583.175 & 386.85 & Cross section 3. \\
42 & 10049.016 & 9585.006 & 387.47 & Cross section 3. \\
43 & 10203.962 & 9925.433 & 405.53 & T-2. \\
44 & 10039.806 & 9583.812 & 388.52 & T-2. \\
\hline 45 & 10032.878 & 9580.408 & 393.10 & T-2 \\
\hline
\end{tabular}


Appendix Table 1. Cross-section survey data collected in February 1997 at eight sites in the Treyburn development study area, North Carolina-Continued

[HUB, turning point; - , no notes; TOB, top of bank; EOW, edge of water; WS, water surface; EOC, edge of channel; SR, secondary road; PK, nail (with, as in PK57, or without an assigned number); TOS, top of slope; MP, midpoint; TORB, top of right bank; TOLB, top of left bank; TRIB, tributary; EOB, edge of bank; RM, reference mark]

\begin{tabular}{|c|c|c|c|c|}
\hline $\begin{array}{l}\text { Data } \\
\text { count }\end{array}$ & $\begin{array}{l}\text { Local } x \\
\text { coordinate }\end{array}$ & $\begin{array}{l}\text { Local y } \\
\text { coordinate }\end{array}$ & $\begin{array}{c}\text { Local } \\
\text { elevation, } \\
\text { in feet, above } \\
\text { arbitrary datum }\end{array}$ & Notes \\
\hline \multicolumn{5}{|c|}{$\begin{array}{l}\text { Site } 5 \mathrm{~T}-02085500 \text {, Flat River at Bahama, N.C. } \\
\text { al II, established by the North Carolina Geological Survev; elevation is } 57\end{array}$} \\
\hline 1 & 50000.000 & 50000.000 & 500.00 & Nail in bridge rail. \\
\hline 2 & 50100.000 & 50000.000 & 500.00 & - \\
\hline 3 & 50110.096 & 50147.780 & 504.43 & Cross section 1. \\
\hline 4 & 50115.622 & 50128.424 & 500.60 & Cross section 1 , TOLB. \\
\hline 5 & 50108.150 & 50113.013 & 492.25 & Cross section 1, EOW. \\
\hline 6 & 50114.753 & 50107.525 & 489.68 & Cross section 1 \\
\hline 7 & 50118.530 & 50100.121 & 489.23 & Cross section 1 . \\
\hline 8 & 50120.549 & 50091.216 & 489.27 & Cross section 1 . \\
\hline 9 & 50126.340 & 50079.877 & 489.93 & Cross section 1 . \\
\hline 10 & 50133.015 & 50069.325 & 490.01 & Cross section 1 . \\
\hline 11 & 50139.994 & 50056.218 & 490.10 & Cross section 1 . \\
\hline 12 & 50145.066 & 50048.941 & 490.68 & Cross section 1 . \\
\hline 13 & 50151.595 & 50041.547 & 491.11 & Cross section 1 , WS. \\
\hline 14 & 50158.407 & 50031.421 & 492.42 & Cross section 1, EOW. \\
\hline 15 & 50161.447 & 50018.101 & 493.16 & Cross section 1 \\
\hline 16 & 50161.571 & 50011.538 & 498.15 & Cross section 1 , TORB. \\
\hline 17 & 50189.123 & 49979.747 & 502.19 & Cross section 1 \\
\hline 18 & 50218.033 & 49917.177 & 504.82 & Cross section 1 . \\
\hline 19 & 50375.843 & 50081.413 & 502.02 & Cross section 2, TOB. \\
\hline 20 & 50358.345 & 50108.096 & 500.36 & Cross section 2, TOB. \\
\hline 21 & 50247.203 & 50038.232 & 498.88 & TRIB TOLB. \\
\hline 22 & 50336.902 & 50107.942 & 491.45 & Cross section 2, EOW. \\
\hline 23 & 50330.939 & 50119.064 & 490.98 & Cross section 2 . \\
\hline 24 & 50327.189 & 50130.636 & 490.55 & Cross section 2 . \\
\hline 25 & 50326.400 & 50138.147 & 489.04 & Cross section 2. \\
\hline 26 & 50336.359 & 50149.815 & 489.17 & Cross section 2, WS. \\
\hline 27 & 50335.452 & 50157.455 & 489.15 & Cross section 2 . \\
\hline 28 & 50333.010 & 50167.385 & 489.29 & Cross section 2. \\
\hline 29 & 50331.407 & 50178.330 & 490.10 & Cross section 2 . \\
\hline 30 & 50326.075 & 50188.903 & 489.93 & Cross section 2 . \\
\hline 31 & 50322.207 & 50199.172 & 490.54 & Cross section 2, EOW. \\
\hline 32 & 50321.570 & 50205.257 & 497.81 & Cross section 2 , TOLB. \\
\hline 33 & 50314.359 & 50226.086 & 505.37 & Cross section 2 . \\
\hline 34 & 50225.673 & 50029.633 & 500.34 & TRIB TORB. \\
\hline 35 & 50096.926 & 49949.657 & 500.34 & Cross section 3 . \\
\hline 36 & 50060.278 & 49988.413 & 492.13 & Cross section 3, EOW. \\
\hline 37 & 50054.058 & 50001.376 & 491.65 & Cross section 3 . \\
\hline 38 & 50048.740 & 50012.336 & 491.33 & Cross section 3 . \\
\hline 39 & 50044.503 & 50022.799 & 490.57 & Cross section 3 . \\
\hline
\end{tabular}


Appendix Table 1. Cross-section survey data collected in February 1997 at eight sites in the Treyburn development study area, North Carolina-Continued

[HUB, turning point; - , no notes; TOB, top of bank; EOW, edge of water; WS, water surface; EOC, edge of channel; SR, secondary road; PK, nail (with, as in PK57, or without an assigned number); TOS, top of slope; MP, midpoint; TORB, top of right bank; TOLB, top of left bank; TRIB, tributary; EOB, edge of bank; RM, reference mark]

\begin{tabular}{ccccc}
\hline $\begin{array}{c}\text { Data } \\
\text { count }\end{array}$ & $\begin{array}{c}\text { Local } \mathbf{x} \\
\text { coordinate }\end{array}$ & $\begin{array}{c}\text { Local } \mathbf{y} \\
\text { coordinate }\end{array}$ & $\begin{array}{c}\text { Local } \\
\text { elevation, } \\
\text { in feet, above } \\
\text { arbitrary datum }\end{array}$ & Notes \\
\hline \multicolumn{5}{c}{ Site 5T-02085500, Flat River at Bahama, N.C. } \\
& & & (Continued) & \\
\hline 40 & 50038.473 & 50030.983 & 489.91 & Cross section 3. \\
41 & 50033.010 & 50040.045 & 490.22 & Cross section 3. \\
42 & 50026.813 & 50050.155 & 490.43 & Cross section 3. \\
43 & 50023.737 & 50054.598 & 491.59 & Cross section 3, EOW. \\
44 & 50019.350 & 50059.061 & 498.19 & Cross section 3, TOLB. \\
45 & 50006.539 & 50080.762 & 506.24 & Cross section 3. \\
\hline
\end{tabular}


Appendix Table 1. Cross-section survey data collected in February 1997 at eight sites in the Treyburn development study area, North Carolina-Continued

[HUB, turning point; - , no notes; TOB, top of bank; EOW, edge of water; WS, water surface; EOC, edge of channel; SR, secondary road; PK, nail (with, as in PK57, or without an assigned number); TOS, top of slope; MP, midpoint; TORB, top of right bank; TOLB, top of left bank; TRIB, tributary; EOB, edge of bank; RM, reference mark]

\begin{tabular}{|c|c|c|c|c|}
\hline $\begin{array}{l}\text { Data } \\
\text { count }\end{array}$ & $\begin{array}{c}\text { Local } x \\
\text { coordinate }\end{array}$ & $\begin{array}{l}\text { Local y } \\
\text { coordinate }\end{array}$ & $\begin{array}{l}\text { Local } \\
\text { elevation, } \\
\text { in feet, above } \\
\text { arbitrary datum }\end{array}$ & Notes \\
\hline \multicolumn{5}{|c|}{$\begin{array}{l}\text { Site } 6 \mathrm{~T}-0208524090, \text { Mountain Creek at SR } 1617 \text { near Bahama, N.C. } \\
\text { General location of the cross sections is } 36^{\circ} 08^{\prime} 58.24^{\prime \prime} \text { latitude, } 78^{\circ} 58^{\prime} 48.96 \text { " longitude. Elevation at PK60 is } 373.23 \\
\text { feet above mean sea level. Local elevation must be adjusted by adding } 173.23 \text { feet to obtain elevation above mean sea } \\
\text { level. }\end{array}$} \\
\hline 1 & 10000.000 & 10000.000 & 200.00 & $\begin{array}{l}\text { PK60 on upstream side of road, left } \\
\text { end of bridge. }\end{array}$ \\
\hline 2 & 10100.000 & 10000.000 & 200.00 & - \\
\hline 3 & 10133.757 & 10039.970 & 197.38 & Cross section 1. \\
\hline 4 & 10108.249 & 10020.484 & 195.80 & Cross section 1 . \\
\hline 5 & 10080.296 & 9993.385 & 195.26 & Cross section 1. \\
\hline 6 & 10058.592 & 9980.125 & 194.82 & Cross section 1. \\
\hline 7 & 10054.940 & 9977.178 & 191.84 & Cross section 1, EOW. \\
\hline 8 & 10051.784 & 9975.483 & 191.11 & Cross section 1 \\
\hline 9 & 10049.177 & 9973.575 & 191.30 & Cross section 1 . \\
\hline 10 & 10046.811 & 9971.291 & 191.37 & Cross section 1 . \\
\hline 11 & 10043.267 & 9969.831 & 190.96 & Cross section 1 . \\
\hline 12 & 10040.021 & 9967.081 & 191.89 & Cross section 1, EOW. \\
\hline 13 & 10037.943 & 9965.108 & 194.35 & Cross section 1 \\
\hline 14 & 10036.076 & 9961.817 & 197.24 & Cross section 1 . \\
\hline 15 & 10028.072 & 9955.740 & 199.79 & Cross section 1 . \\
\hline 16 & 10023.249 & 9950.478 & 204.17 & Cross section 1. \\
\hline 17 & 10068.543 & 9920.705 & 205.78 & Cross section 2. \\
\hline 18 & 10000.000 & 10000.000 & 200.61 & Cross section 2. \\
\hline 19 & 10072.505 & 9932.513 & 201.64 & Cross section 2. \\
\hline 20 & 10076.435 & 9940.079 & 195.51 & Cross section 2 \\
\hline 21 & 10076.790 & 9942.615 & 192.83 & Cross section 2, EOW. \\
\hline 22 & 10078.076 & 9946.072 & 192.20 & Cross section 2. \\
\hline 23 & 10079.799 & 9948.854 & 192.21 & Cross section 2. \\
\hline 24 & 10080.829 & 9951.030 & 192.22 & Cross section 2. \\
\hline 25 & 10080.956 & 9952.123 & 192.81 & Cross section 2. \\
\hline 26 & 10081.962 & 9955.143 & 192.45 & Cross section 2. \\
\hline 27 & 10083.077 & 9957.688 & 192.62 & Cross section 2 . \\
\hline 28 & 10083.897 & 9960.360 & 192.70 & Cross section 2, EOW. \\
\hline 29 & 10085.674 & 9964.928 & 194.65 & Cross section 2 \\
\hline 30 & 10080.866 & 9954.862 & 192.23 & WS. \\
\hline 31 & 10089.857 & 9976.566 & 196.01 & Cross section 2. \\
\hline 32 & 10099.391 & 9992.784 & 195.13 & Cross section 2 . \\
\hline 33 & 10109.494 & 10022.194 & 195.88 & Cross section 2. \\
\hline 34 & 10011.114 & 10033.189 & 198.51 & Cross section 2 . \\
\hline 35 & 10182.134 & 10079.362 & 200.04 & Cross section 3 . \\
\hline 36 & 10182.786 & 10045.969 & 195.64 & Cross section 3 . \\
\hline 37 & 10184.265 & 9989.429 & 195.74 & Cross section 3. \\
\hline 38 & 10183.899 & 9966.534 & 196.02 & Cross section 3 , TOB. \\
\hline 39 & 10181.971 & 9959.954 & 192.79 & Cross section 3, EOW. \\
\hline
\end{tabular}


Appendix Table 1. Cross-section survey data collected in February 1997 at eight sites in the Treyburn development study area, North Carolina-Continued

[HUB, turning point; - , no notes; TOB, top of bank; EOW, edge of water; WS, water surface; EOC, edge of channel; SR, secondary road; PK, nail (with, as in PK57, or without an assigned number); TOS, top of slope; MP, midpoint; TORB, top of right bank; TOLB, top of left bank; TRIB, tributary; EOB, edge of bank; RM, reference mark]

\begin{tabular}{|c|c|c|c|c|}
\hline $\begin{array}{l}\text { Data } \\
\text { count }\end{array}$ & $\begin{array}{l}\text { Local } x \\
\text { coordinate }\end{array}$ & $\begin{array}{l}\text { Local y } \\
\text { coordinate }\end{array}$ & $\begin{array}{c}\text { Local } \\
\text { elevation, } \\
\text { in feet, above } \\
\text { arbitrary datum }\end{array}$ & Notes \\
\hline \multicolumn{5}{|c|}{ Site 6T-0208524090, Mountain Creek at SR 1617 near Bahama, N.C. } \\
\hline 40 & 10182.467 & 9954.534 & 192.27 & Cross section 3. \\
\hline 41 & 10183.125 & 9950.627 & 192.46 & Cross section 3 . \\
\hline 42 & 10184.340 & 9940.489 & 192.99 & Cross section 3, EOW. \\
\hline 43 & 10185.034 & 9933.353 & 195.84 & Cross section 3 , TOB. \\
\hline 44 & 10185.290 & 9924.316 & 197.87 & Cross section 3 . \\
\hline 45 & 10185.542 & 9905.518 & 203.37 & Cross section 3 . \\
\hline 46 & 10259.382 & 9886.724 & 206.79 & Cross section 4. \\
\hline 47 & 10259.457 & 9906.980 & 197.20 & Cross section 4 \\
\hline 48 & 10259.983 & 9917.424 & 196.64 & Cross section 4 , TOB TRIB. \\
\hline 49 & 10257.807 & 9928.934 & 193.43 & Cross section 4 , center. \\
\hline 50 & 10257.227 & 9931.824 & 196.85 & Cross section 4, TOB TRIB. \\
\hline 51 & 10254.772 & 9943.603 & 196.81 & Cross section 4 \\
\hline 52 & 10250.117 & 9958.176 & 195.81 & Cross section 4 , TOB. \\
\hline 53 & 10248.478 & 9962.532 & 193.63 & Cross section 4, EOW. \\
\hline 54 & 10246.941 & 9966.978 & 193.25 & Cross section 4 \\
\hline 55 & 10245.871 & 9971.087 & 192.76 & Cross section 4. \\
\hline 56 & 10245.082 & 9973.971 & 192.49 & Cross section 4. \\
\hline 57 & 10243.115 & 9977.524 & 192.75 & Cross section 4, EOW. \\
\hline 58 & 10238.139 & 9980.555 & 197.01 & Cross section 4, TOB. \\
\hline 59 & 10240.329 & 9992.500 & 196.65 & Cross section 4 \\
\hline 60 & 10238.470 & 10017.140 & 196.67 & Cross section 4. \\
\hline 61 & 10234.964 & 10035.401 & 196.57 & Cross section 4. \\
\hline 62 & 10229.292 & 10053.141 & 196.67 & Cross section 4. \\
\hline 63 & 10226.507 & 10070.429 & 196.81 & Cross section 4. \\
\hline 64 & 10222.737 & 10094.642 & 201.11 & Cross section 4 \\
\hline 65 & 10027.427 & 10032.063 & 200.26 & $\begin{array}{l}\text { PK52 (from PK60, angle } 49^{\circ} 27^{\prime} 20^{\prime \prime} \\
\text { a distance of } 42.16 \text { feet; height } \\
-0.35 \text { feet). }\end{array}$ \\
\hline
\end{tabular}


Appendix Table 1. Cross-section survey data collected in February 1997 at eight sites in the Treyburn development study area, North Carolina-Continued

[HUB, turning point; - , no notes; TOB, top of bank; EOW, edge of water; WS, water surface; EOC, edge of channel; SR, secondary road; PK, nail (with, as in PK57, or without an assigned number); TOS, top of slope; MP, midpoint; TORB, top of right bank; TOLB, top of left bank; TRIB, tributary; EOB, edge of bank; RM, reference mark]

\begin{tabular}{|c|c|c|c|c|}
\hline $\begin{array}{l}\text { Data } \\
\text { count }\end{array}$ & $\begin{array}{c}\text { Local } x \\
\text { coordinate }\end{array}$ & $\begin{array}{l}\text { Local y } \\
\text { coordinate }\end{array}$ & $\begin{array}{l}\text { Local } \\
\text { elevation, } \\
\text { in feet, above } \\
\text { arbitrary datum }\end{array}$ & Notes \\
\hline \multicolumn{5}{|c|}{$\begin{array}{l}\text { Site } 8 \mathrm{~T}-0208524950 \text {, Little River tributary at Fairntosh, N.C. } \\
\text { General location of the cross sections is } 36^{\circ} 06^{\prime} 55.90^{\prime \prime} \text { latitude, } 78^{\circ} 51^{\prime} 29.55^{\prime \prime} \text { longitude. Elevation is } 276.74 \text { feet above } \\
\text { mean sea level. Local elevation must be adjusted by subtracting } 23.26 \text { feet to obtain elevation above mean sea level. }\end{array}$} \\
\hline 1 & 10000.000 & 10000.000 & 300.00 & - \\
\hline 2 & 10100.000 & 10000.000 & 300.00 & - \\
\hline 3 & 10017.013 & 10022.412 & 299.74 & Cross section 1 . \\
\hline 4 & 10031.463 & 9999.591 & 299.93 & Cross section 1. \\
\hline 5 & 10033.905 & 9992.142 & 301.05 & Cross section 1 , TOB. \\
\hline 6 & 10034.862 & 9987.293 & 300.13 & Cross section 1, EOB. \\
\hline 7 & 10035.200 & 9985.011 & 297.20 & Cross section 1, EOW. \\
\hline 8 & 10035.599 & 9982.851 & 296.72 & Cross section 1 \\
\hline 9 & 10036.191 & 9980.721 & 296.43 & Cross section 1 . \\
\hline 10 & 10036.700 & 9978.787 & 296.40 & Cross section 1 . \\
\hline 11 & 10036.957 & 9977.425 & 296.94 & Cross section 1, EOW. \\
\hline 12 & 10037.338 & 9979.950 & 296.48 & WS. \\
\hline 13 & 10037.459 & 9975.967 & 299.62 & Cross section 1 , TOB. \\
\hline 14 & 10040.265 & 9964.100 & 300.58 & Cross section 1 \\
\hline 15 & 10049.446 & 9932.995 & 300.18 & Cross section 1 . \\
\hline 16 & 9986.061 & 9912.976 & 299.38 & Cross section 2 . \\
\hline 17 & 9975.861 & 9937.657 & 299.38 & Cross section 2 \\
\hline 18 & 9972.240 & 9948.016 & 299.15 & Cross section 2, TOB. \\
\hline 19 & 9972.485 & 9950.097 & 296.95 & Cross section 2 \\
\hline 20 & 9971.716 & 9952.176 & 297.05 & Cross section $2, \mathrm{WS}$. \\
\hline 21 & 9970.980 & 9954.103 & 297.25 & Cross section 2 . \\
\hline 22 & 9970.838 & 9955.483 & 296.98 & Cross section 2 \\
\hline 23 & 9970.496 & 9956.393 & 296.82 & Cross section 2 , WS. \\
\hline 24 & 9970.180 & 9957.595 & 296.86 & Cross section 2, EOW. \\
\hline 25 & 9970.539 & 9961.028 & 299.48 & Cross section 2, TOB. \\
\hline 26 & 9960.785 & 9987.014 & 299.18 & Cross section 2. \\
\hline 27 & 9846.604 & 9965.036 & 298.46 & Cross section 3 . \\
\hline 28 & 9861.034 & 9931.210 & 298.40 & Cross section 3 . \\
\hline 29 & 9863.747 & 9919.754 & 297.25 & Cross section 3 , TOB. \\
\hline 30 & 9864.393 & 9917.581 & 296.37 & Cross section 3, EOW. \\
\hline 31 & 9866.803 & 9912.704 & 295.75 & Cross section 3 . \\
\hline 32 & 9867.249 & 9911.777 & 295.90 & Cross section 3 . \\
\hline 33 & 9866.195 & 9909.950 & 298.89 & Cross section 3 , TOB. \\
\hline 34 & 9873.310 & 9889.994 & 298.48 & Cross section 3 . \\
\hline 35 & 9996.790 & 10055.363 & 300.06 & - \\
\hline 36 & 9995.104 & 10084.451 & 300.14 & - \\
\hline
\end{tabular}


Appendix Table 1. Cross-section survey data collected in February 1997 at eight sites in the Treyburn development study area, North Carolina-Continued

[HUB, turning point; - , no notes; TOB, top of bank; EOW, edge of water; WS, water surface; EOC, edge of channel; SR, secondary road; PK, nail (with, as in PK57, or without an assigned number); TOS, top of slope; MP, midpoint; TORB, top of right bank; TOLB, top of left bank; TRIB, tributary; EOB, edge of bank; RM, reference mark]

\begin{tabular}{cccc}
\hline $\begin{array}{c}\text { Data } \\
\text { count }\end{array}$ & $\begin{array}{c}\text { Local } x \\
\text { coordinate }\end{array}$ & $\begin{array}{c}\text { Local } y \\
\text { coordinate }\end{array}$ & $\begin{array}{c}\text { elevation, } \\
\text { in feet, above } \\
\text { arbitrary datum }\end{array}$ \\
\hline
\end{tabular}

\begin{tabular}{|c|c|c|c|c|}
\hline \multicolumn{5}{|c|}{$\begin{array}{l}\text { Site 10TA - } 0208524975 \text {, Little River below Little River tributary } \\
\text { at Fairntosh, N.C. } \\
\text { General location of the cross sections is } 36^{\circ} 06^{\prime} 47.22^{\prime \prime} \text { latitude, } 78^{\circ} 51^{\prime} 36.23^{\prime \prime} \text { longitude. Elevation at bolt in bridge is } \\
286.14 \text { feet above mean sea level. Local elevation must be adjusted by adding } 186.14 \text { feet to obtain elevation above } \\
\text { mean sea level. }\end{array}$} \\
\hline 1 & 10000.000 & 10000.000 & 100.00 & Bolt in bridge expansion joint. \\
\hline 2 & 10100.000 & 10000.000 & 100.00 & - \\
\hline 3 & 9698.923 & 10104.151 & 90.39 & Cross section 1 . \\
\hline 4 & 9753.269 & 10152.980 & 89.56 & Cross section 1 . \\
\hline 5 & 9767.241 & 10163.114 & 89.43 & Cross section 1 . \\
\hline 6 & 9778.438 & 10171.071 & 84.48 & Cross section 1 . \\
\hline 7 & 9789.125 & 10180.343 & 80.52 & Cross section 1. \\
\hline 8 & 9796.161 & 10187.139 & 79.75 & Cross section 1, EOW. \\
\hline 9 & 9802.242 & 10194.581 & 79.04 & Cross section 1 \\
\hline 10 & 9810.122 & 10202.308 & 78.48 & Cross section 1. \\
\hline 11 & 9816.618 & 10209.743 & 79.34 & Cross section 1 . \\
\hline 12 & 9823.683 & 10216.540 & 78.69 & Cross section 1 \\
\hline 13 & 9827.407 & 10220.050 & 78.44 & Cross section 1, EOW. \\
\hline 14 & 9833.359 & 10225.602 & 84.68 & Cross section 1 . \\
\hline 15 & 9837.899 & 10230.006 & 90.47 & Cross section 1. \\
\hline 16 & 9855.625 & 10249.491 & 90.38 & Cross section 1. \\
\hline 17 & 9807.075 & 10295.148 & 90.41 & Cross section 2 . \\
\hline 18 & 9785.096 & 10273.326 & 89.84 & Cross section 2 . \\
\hline 19 & 9778.373 & 10264.228 & 83.86 & Cross section 2 \\
\hline 20 & 9771.026 & 10254.339 & 80.27 & Cross section 2, EOW. \\
\hline 21 & 9765.590 & 10246.609 & 79.65 & Cross section 2 \\
\hline 22 & 9809.299 & 10209.527 & 79.32 & WS. \\
\hline 23 & 9760.692 & 10238.001 & 79.48 & Cross section 2 . \\
\hline 24 & 9753.590 & 10230.665 & 79.62 & Cross section 2 . \\
\hline 25 & 9747.124 & 10222.288 & 79.79 & Cross section 2 \\
\hline 26 & 9740.457 & 10212.528 & 79.82 & Cross section 2, EOW. \\
\hline 27 & 9734.956 & 10199.443 & 89.82 & Cross section 2 \\
\hline 28 & 9700.913 & 10160.845 & 90.21 & Cross section 2 . \\
\hline 29 & 9659.542 & 10416.391 & 90.30 & Cross section 3 . \\
\hline 30 & 9643.979 & 10404.518 & 88.31 & Cross section 3 . \\
\hline 31 & 9624.356 & 10391.452 & 79.79 & Cross section 3, EOW. \\
\hline 32 & 9619.629 & 10386.862 & 79.33 & Cross section 3. \\
\hline 33 & 9613.198 & 10380.368 & 78.62 & Cross section 3 . \\
\hline 34 & 9607.119 & 10375.153 & 78.22 & Cross section 3 . \\
\hline 35 & 9601.032 & 10369.430 & 77.97 & Cross section 3 . \\
\hline 36 & 9595.906 & 10365.643 & 78.19 & Cross section 3 . \\
\hline 37 & 9590.622 & 10361.904 & 78.76 & Cross section 3. \\
\hline 38 & 9586.245 & 10359.249 & 79.69 & Cross section 3, EOW. \\
\hline
\end{tabular}


Appendix Table 1. Cross-section survey data collected in February 1997 at eight sites in the Treyburn development study area, North Carolina-Continued

[HUB, turning point; - , no notes; TOB, top of bank; EOW, edge of water; WS, water surface; EOC, edge of channel; SR, secondary road; $\mathrm{PK}$, nail (with, as in PK57, or without an assigned number); TOS, top of slope; MP, midpoint; TORB, top of right bank; TOLB, top of left bank; TRIB, tributary; EOB, edge of bank; RM, reference mark]

\begin{tabular}{|c|c|c|c|c|}
\hline $\begin{array}{l}\text { Data } \\
\text { count }\end{array}$ & $\begin{array}{c}\text { Local } x \\
\text { coordinate }\end{array}$ & $\begin{array}{l}\text { Local y } \\
\text { coordinate }\end{array}$ & $\begin{array}{l}\text { Local } \\
\text { elevation, } \\
\text { in feet, above } \\
\text { arbitrary datum }\end{array}$ & Notes \\
\hline \multicolumn{5}{|c|}{$\begin{array}{l}\text { Site 10TA - 0208524975, Little River below Little River tributary } \\
\text { at Fairntosh, N.C. } \\
\text { (Continued) }\end{array}$} \\
\hline 39 & 9582.501 & 10356.648 & 83.28 & Cross section 3. \\
\hline 40 & 9574.360 & 10345.172 & 91.16 & Cross section 3 . \\
\hline 41 & 9598.405 & 10365.868 & 77.98 & WS. \\
\hline 42 & 10152.149 & 10232.692 & 99.68 & $\begin{array}{l}\text { PK54 on downstream side of road } \\
\text { off left side of bridge (from point } \\
1 \text {, angle } 56^{\circ} 49^{\prime} 20^{\prime \prime} \text { a distance of } \\
278.03 \text { feet; height }-0.91 \text { feet). }\end{array}$ \\
\hline 43 & 9990.714 & 9992.642 & 101.50 & $\mathrm{RM}$ at bridge. \\
\hline 44 & 9803.604 & 9695.188 & 100.82 & $\begin{array}{l}\text { PK50 on downstream side of road } \\
\text { off the right side of bridge (from } \\
\text { point } 1 \text {, angle } 37^{\circ} 12^{\prime} 20^{\prime \prime} \text { a distance } \\
\text { of } 362.59 \text { feet; height } 0.25 \text { feet). }\end{array}$ \\
\hline
\end{tabular}




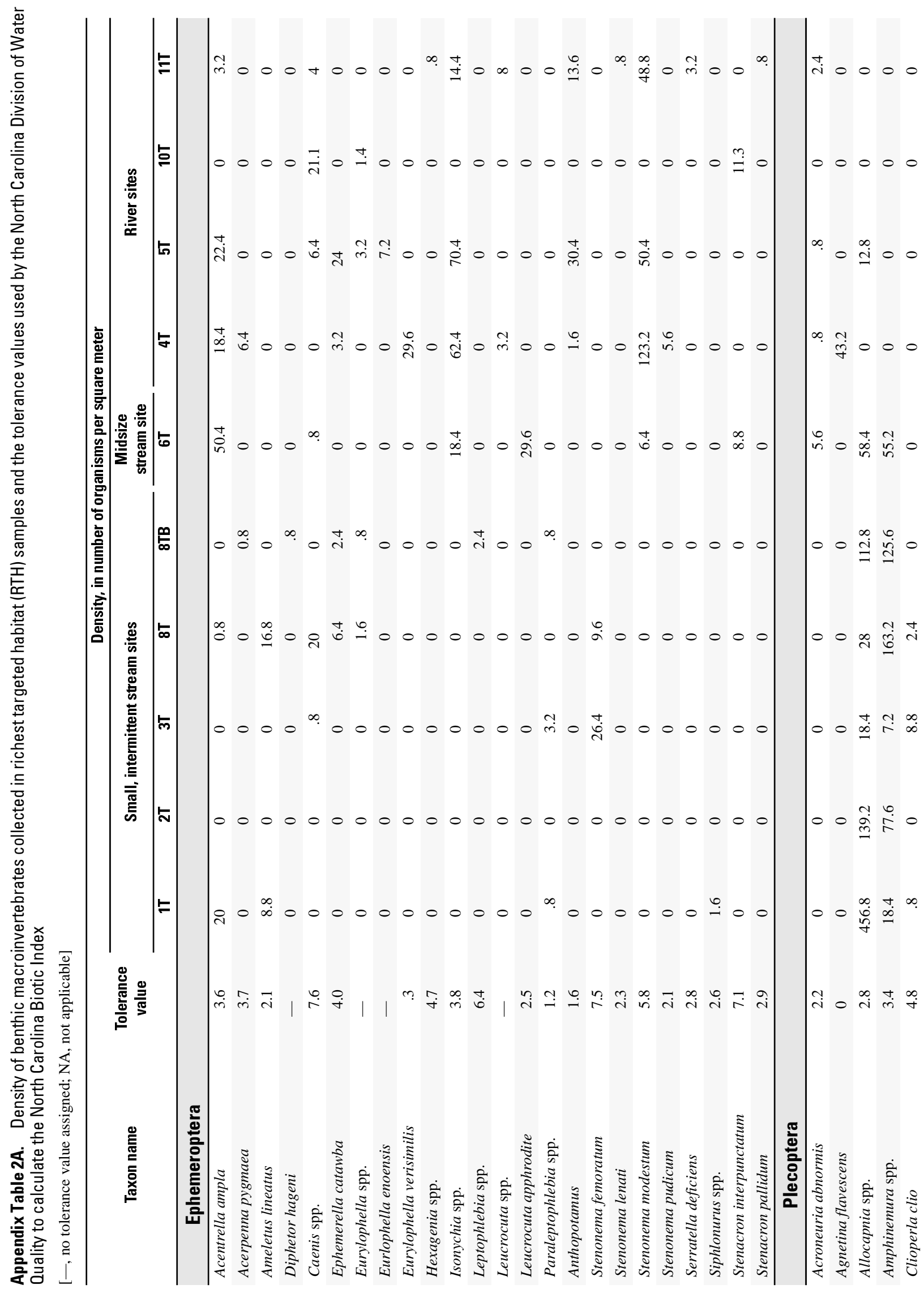




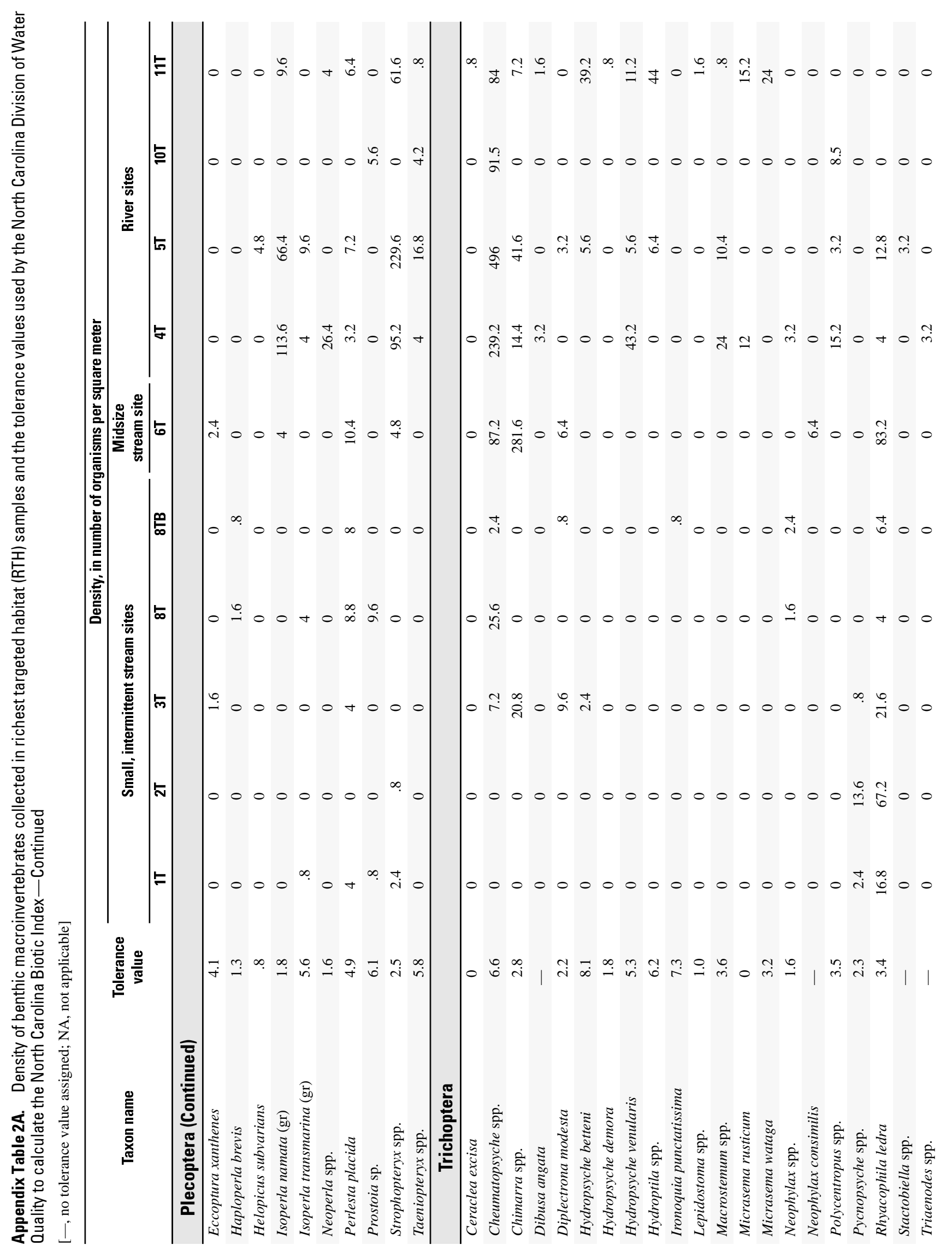




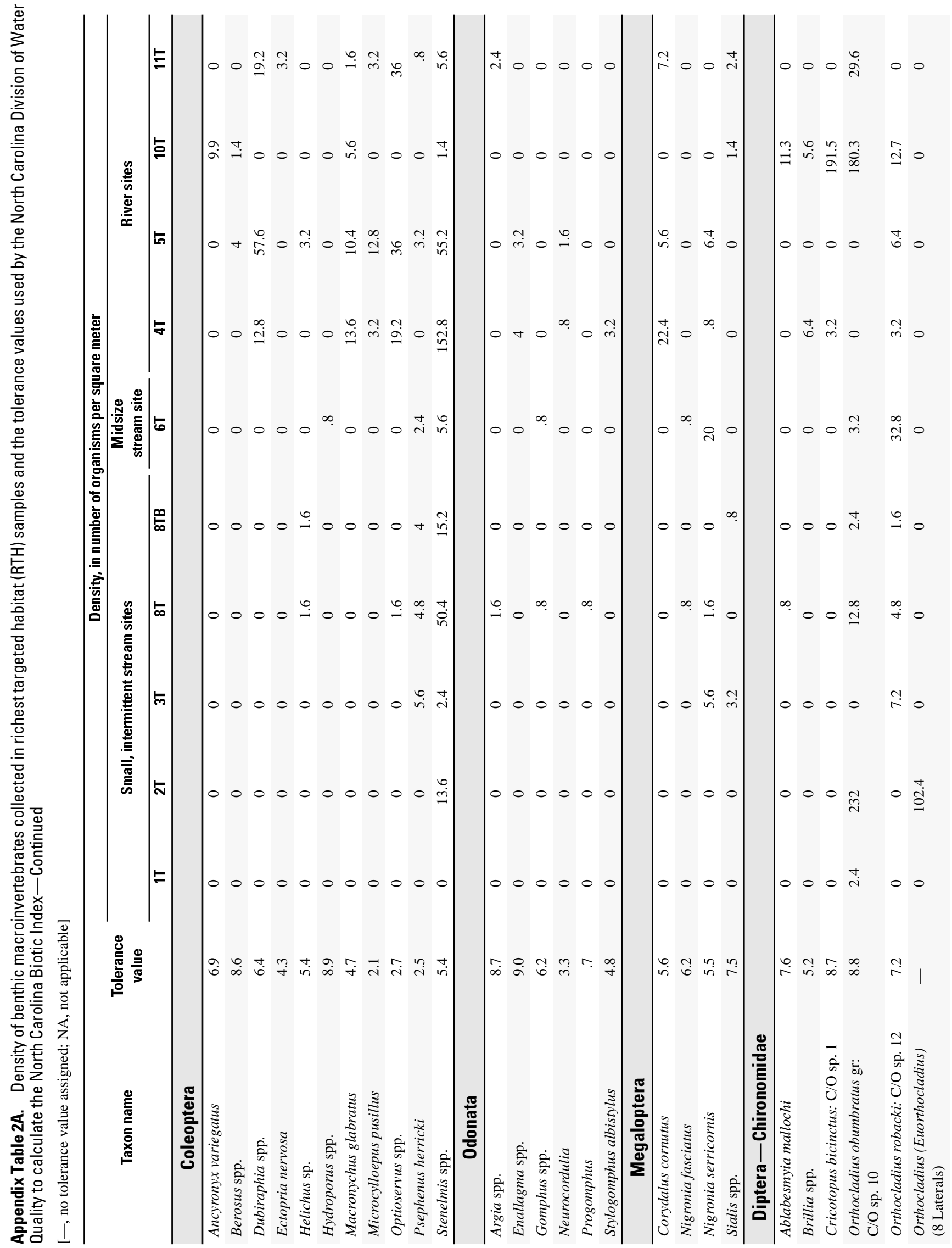

72 Water-Quality and Physical Characteristics of Streams in the Treyburn Development Area of Falls Lake Watershed, North Carolina, 1994-98 


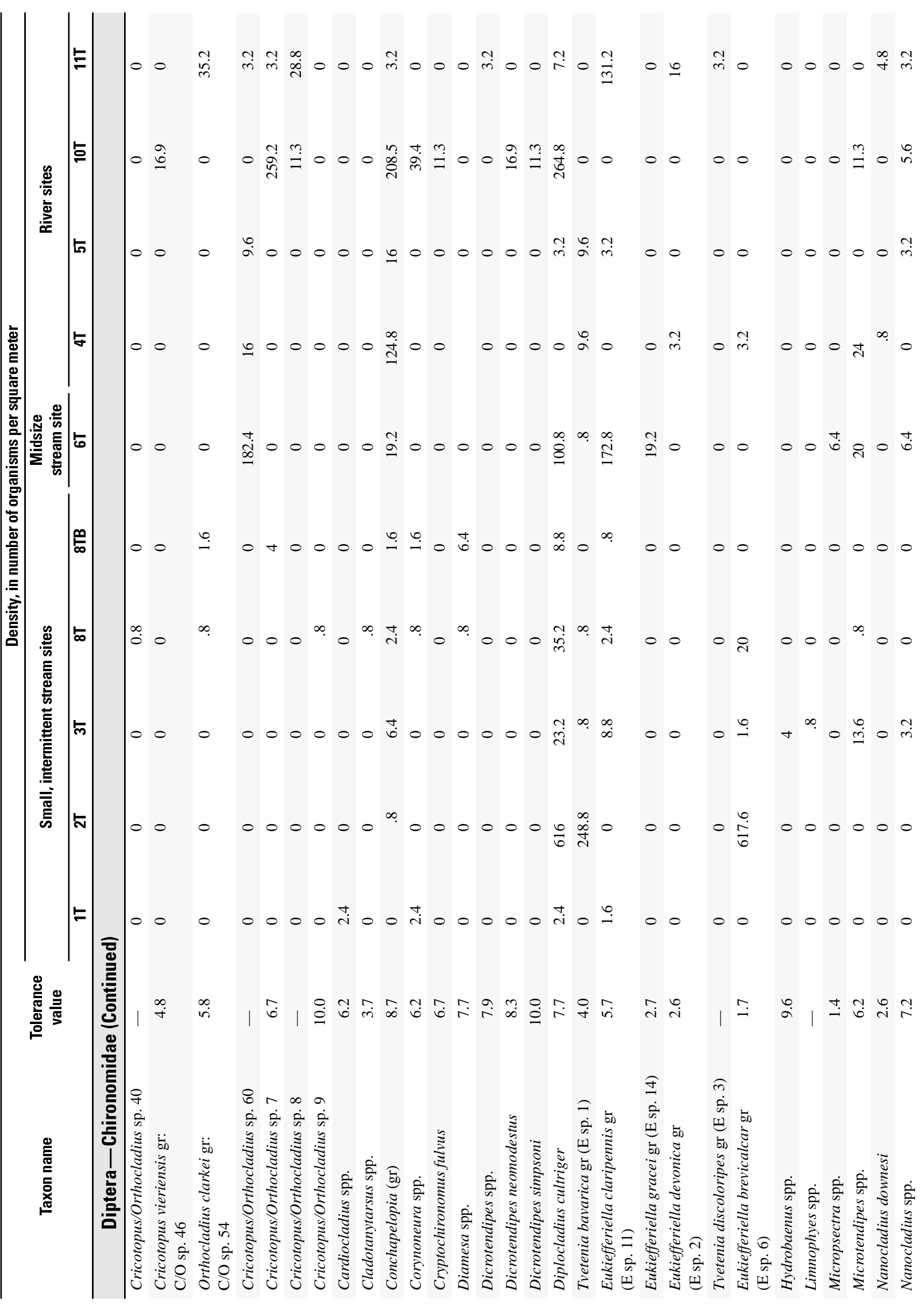




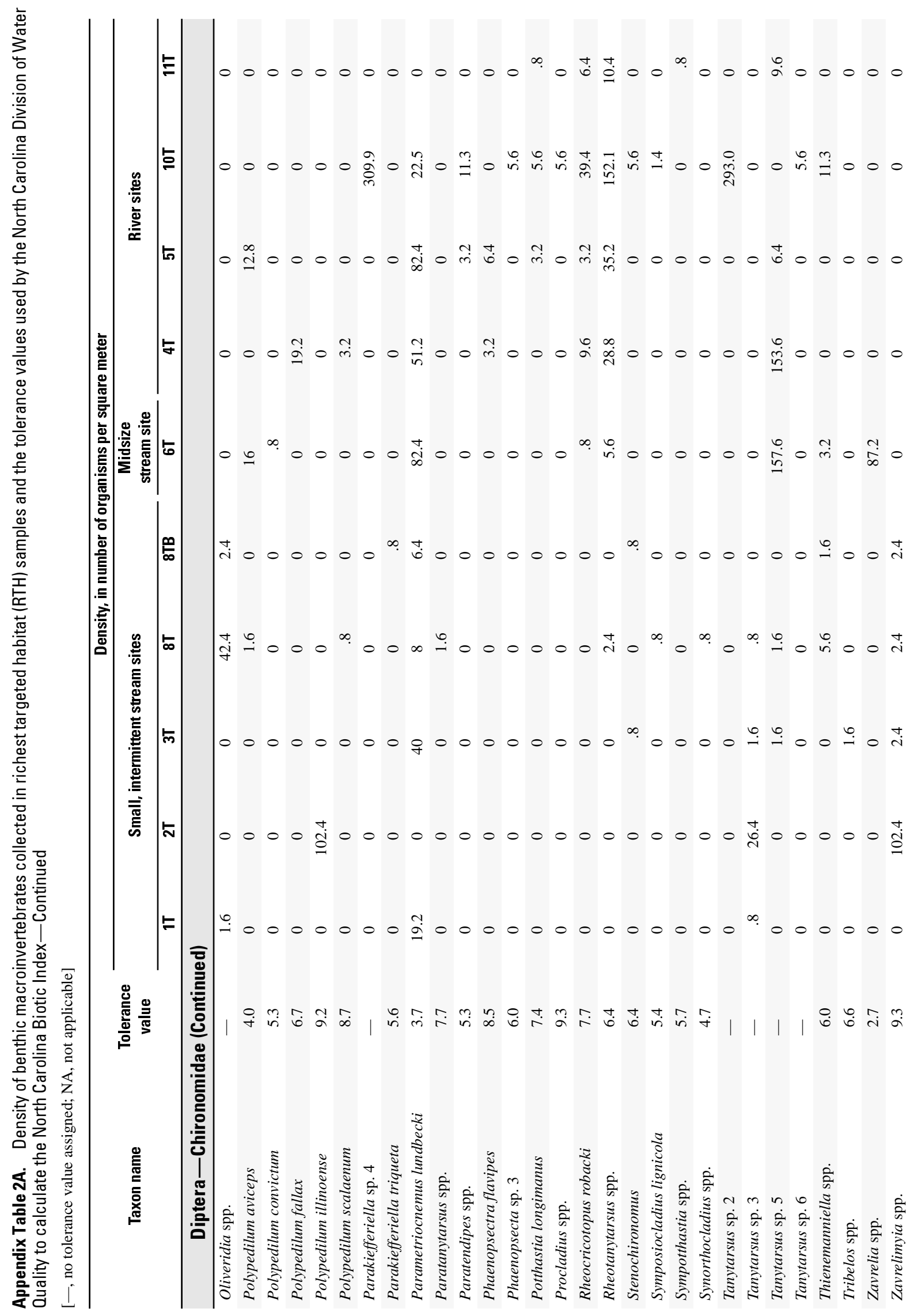




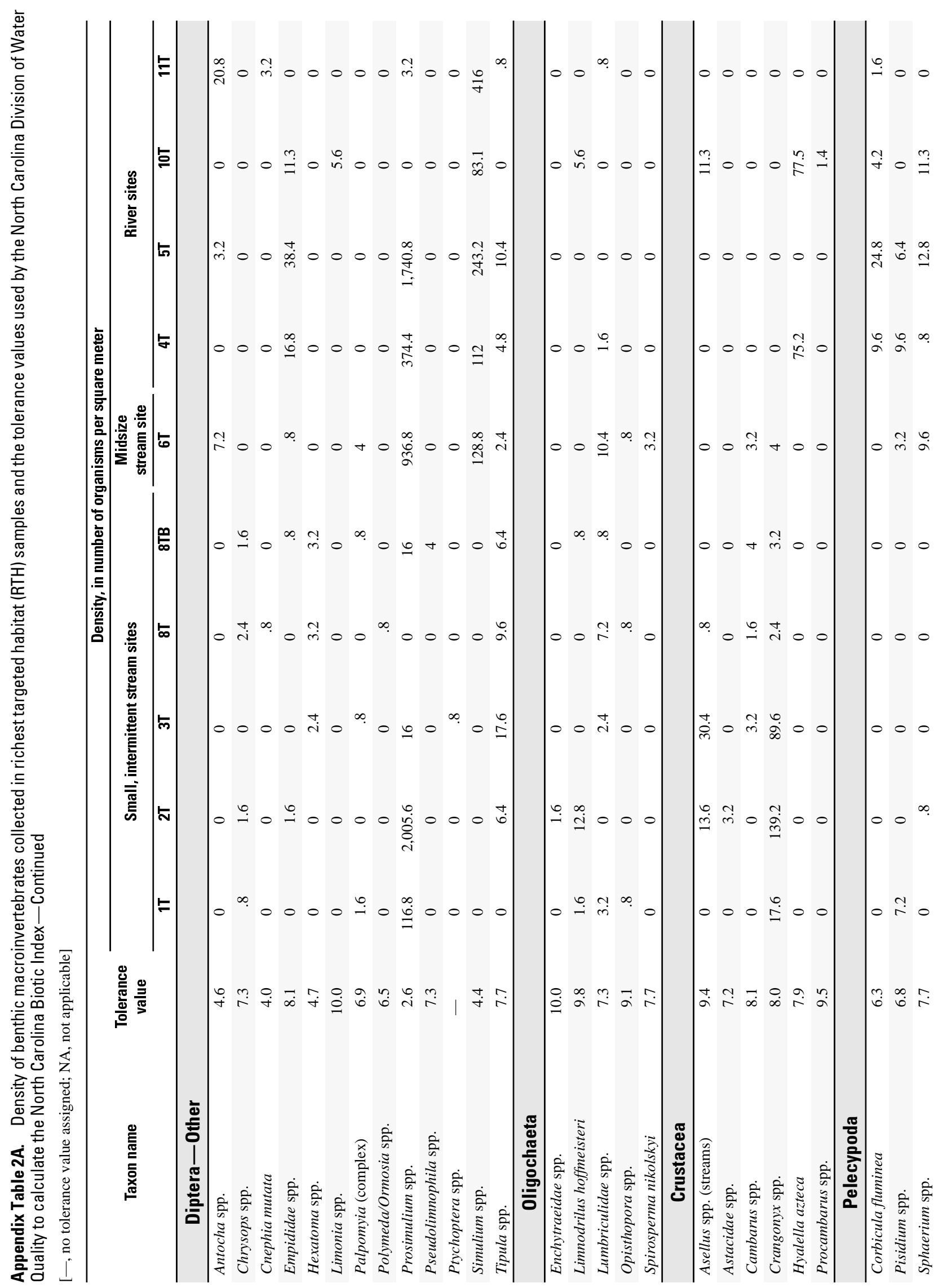




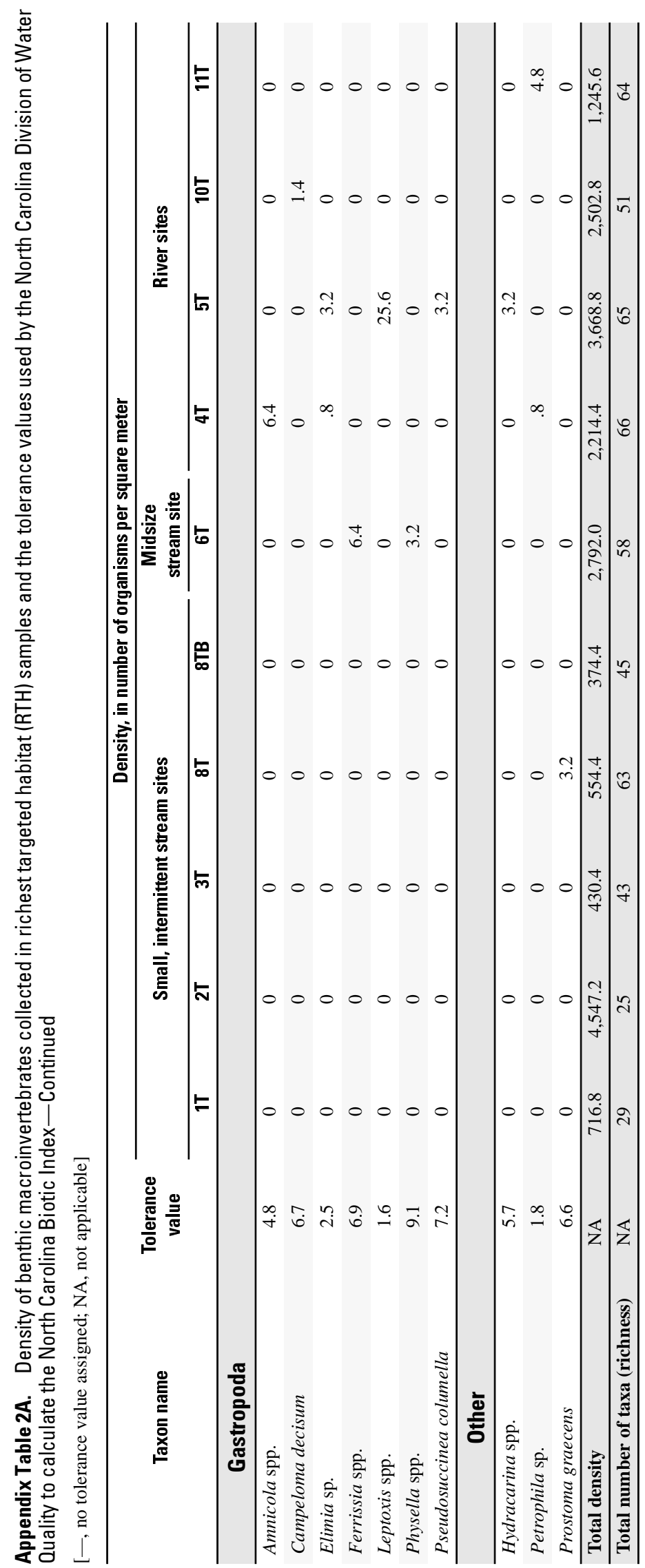




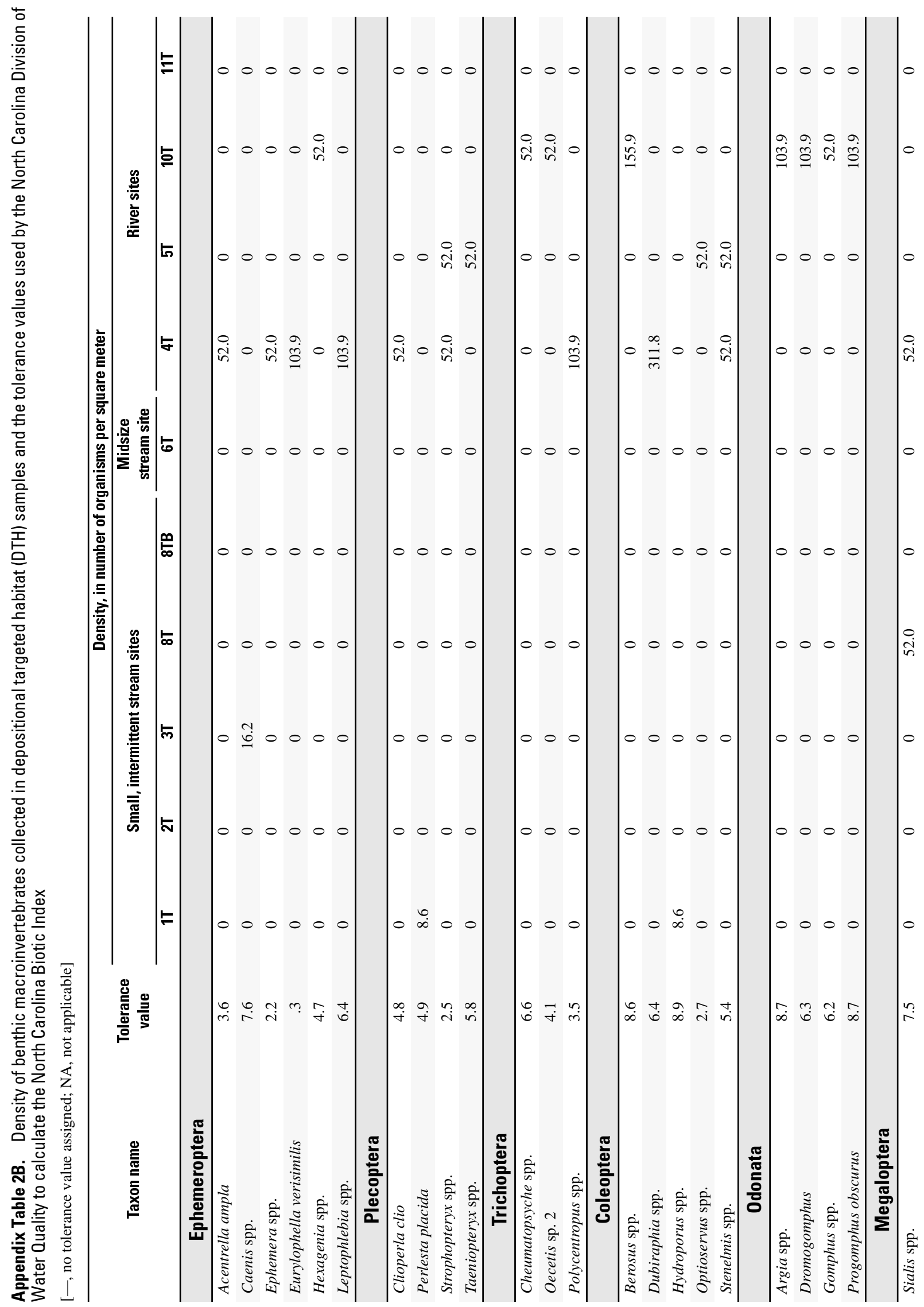




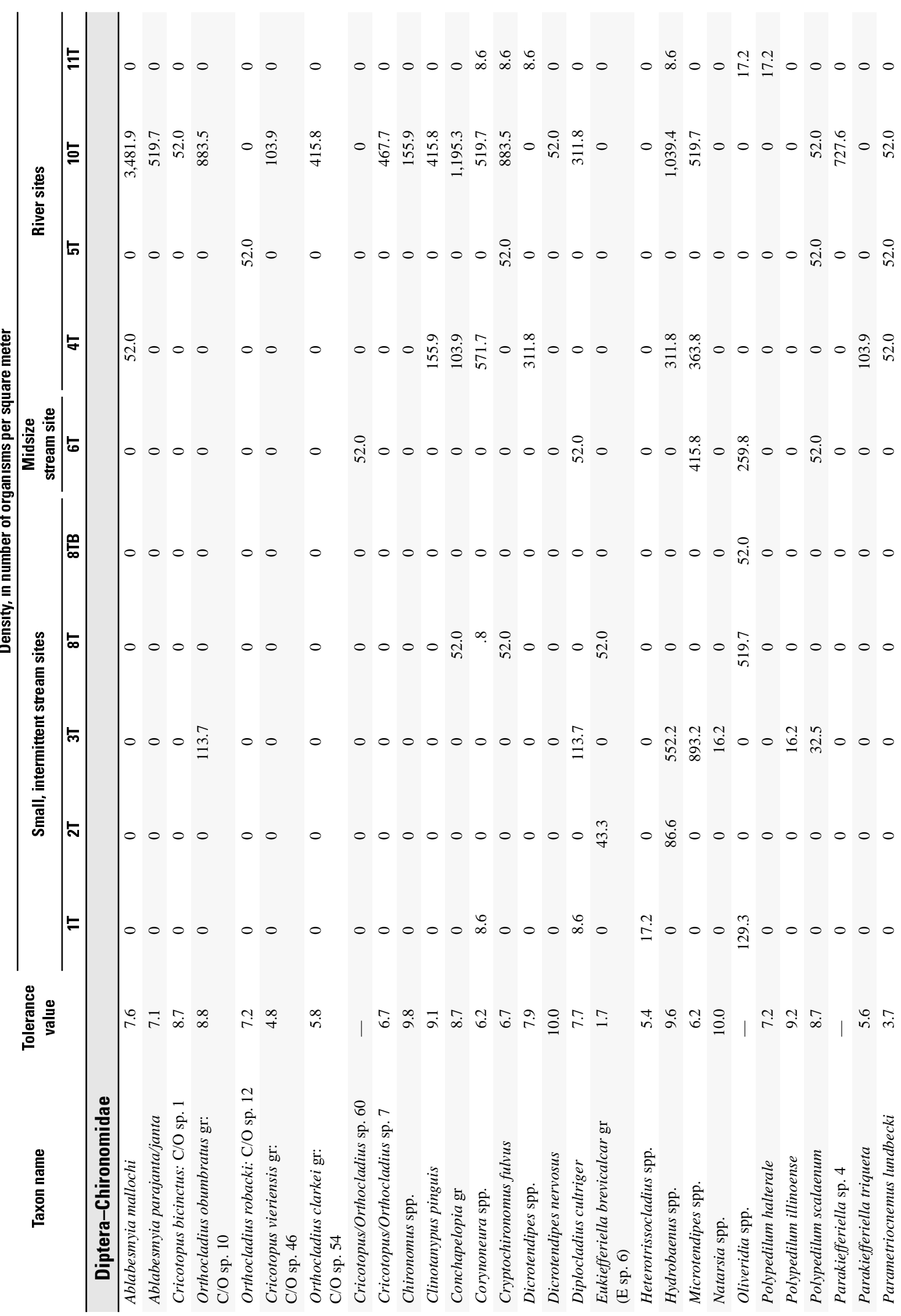




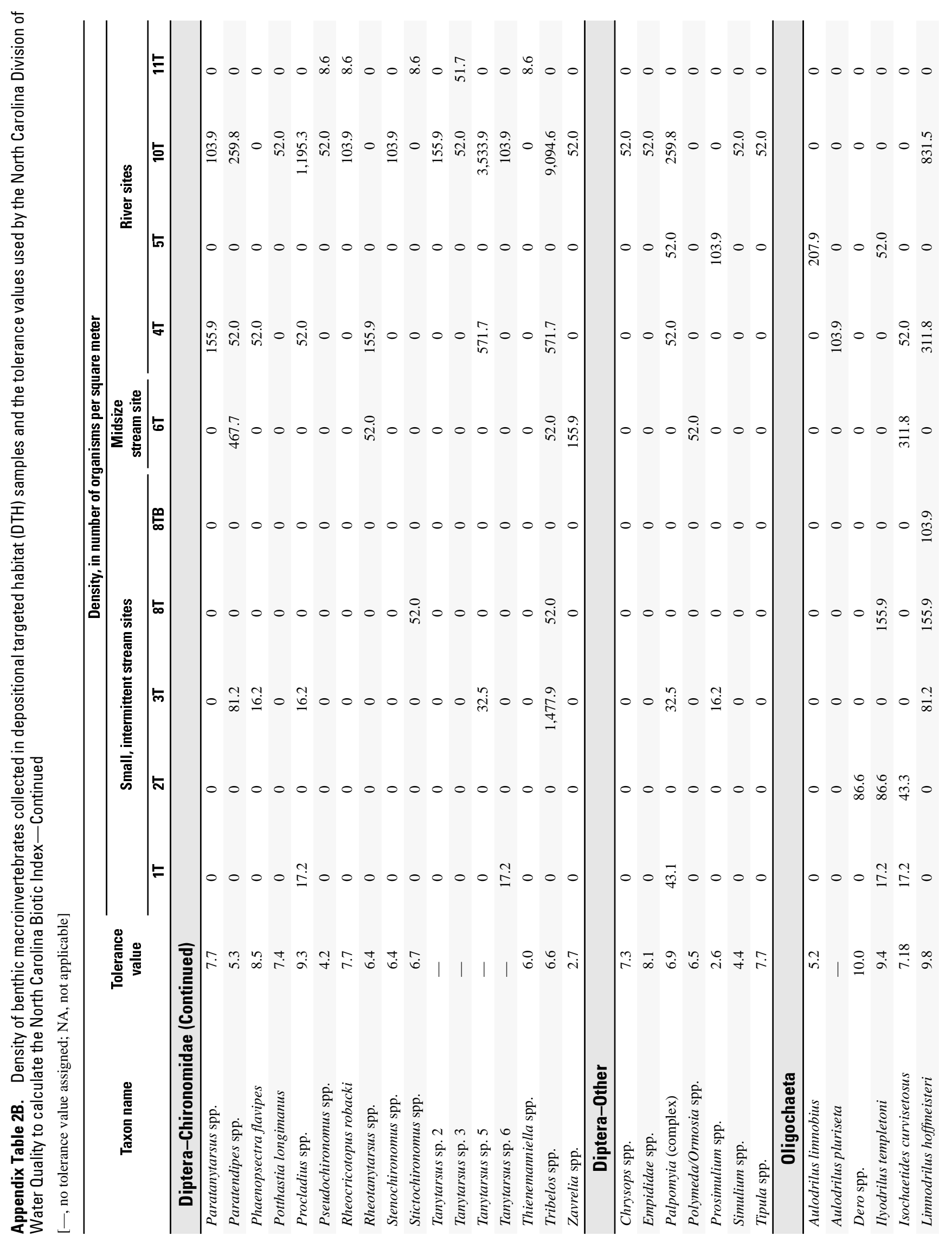




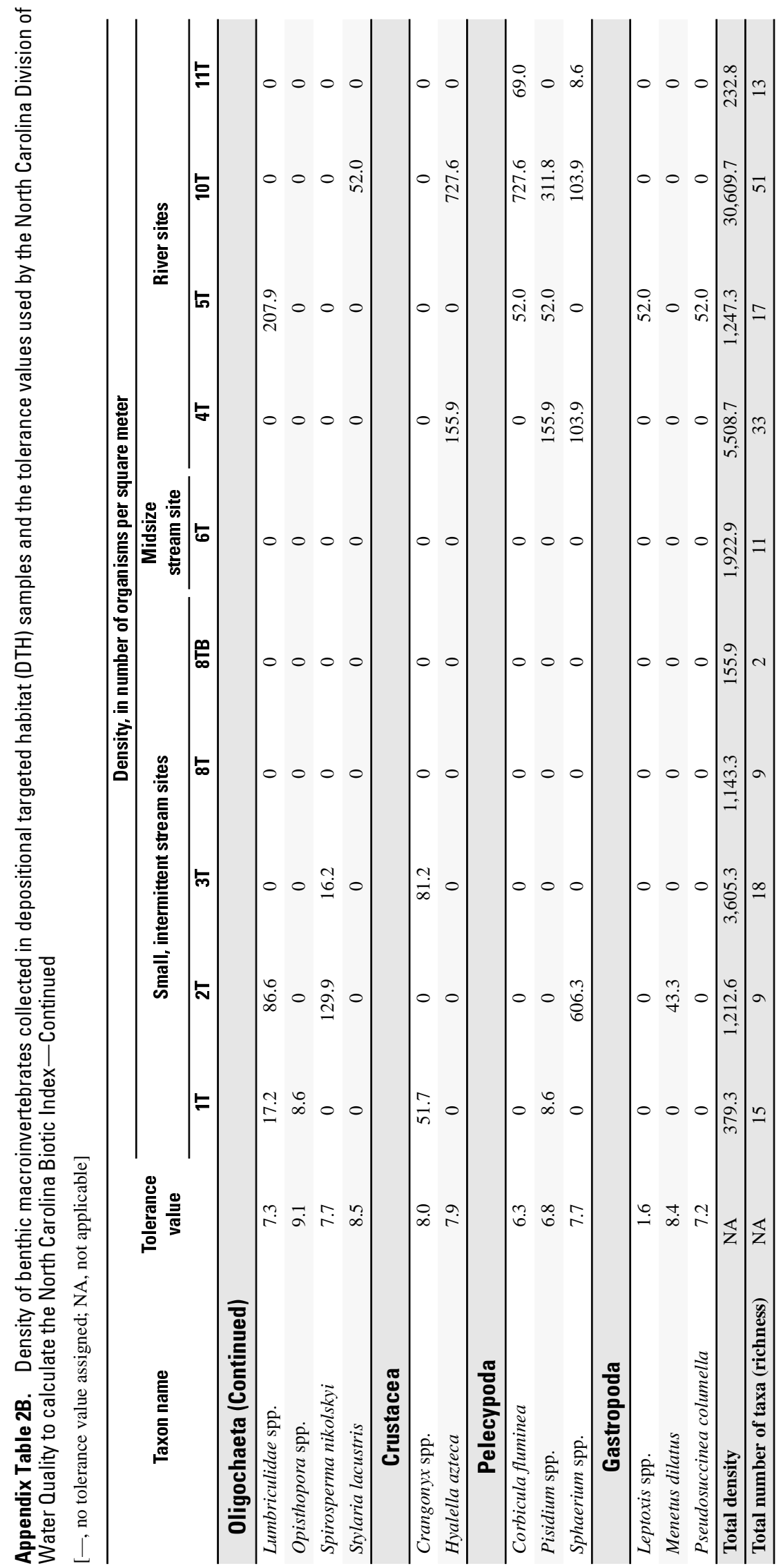

